Florida International University FIU Digital Commons

$7-31-2014$

\title{
Can Compensation Committees Effectively Mitigate the CEO Horizon Problem? The Role of Co-opted Directors
}

Ruonan Liu

Florida International University, ruonan77@gmail.com

DOI: $10.25148 /$ etd.FI14071194

Follow this and additional works at: https://digitalcommons.fiu.edu/etd

Part of the Accounting Commons

\section{Recommended Citation}

Liu, Ruonan, "Can Compensation Committees Effectively Mitigate the CEO Horizon Problem? The Role of Co-opted Directors" (2014). FIU Electronic Theses and Dissertations. 1575.

https://digitalcommons.fiu.edu/etd/1575

This work is brought to you for free and open access by the University Graduate School at FIU Digital Commons. It has been accepted for inclusion in FIU Electronic Theses and Dissertations by an authorized administrator of FIU Digital Commons. For more information, please contact dcc@fiu.edu. 


\section{FLORIDA INTERNATIONAL UNIVERSITY}

Miami, Florida

\section{CAN COMPENSATION COMMITTEES EFFECTIVELY MITIGATE THE CEO HORIZON PROBLEM? THE ROLE OF CO-OPTED DIRECTORS}

A dissertation submitted in partial fulfillment of

the requirements for the degree of

DOCTOR OF PHILOSOPHY

in

ACCOUNTING

by

Ruonan Liu

2014 
To: Dean David R. Klock

College of Business Administration

This dissertation, written by Ruonan Liu, and entitled Can Compensation Committees Effectively Mitigate the CEO Horizon Problem? The Role of Co-opted Directors, having been approved in respect to style and intellectual content, is referred to you for judgment.

We have read this dissertation and recommend that it be approved.

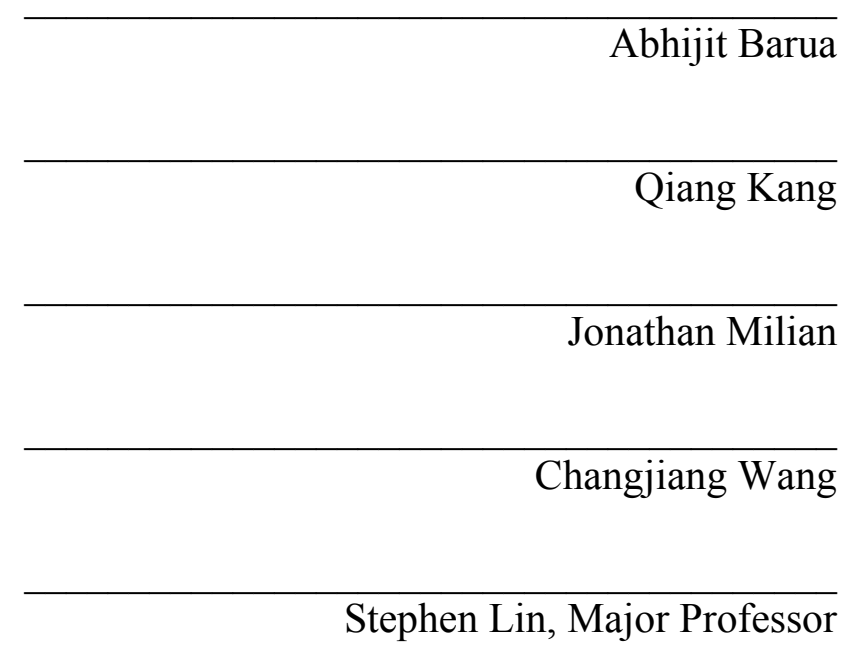

Date of Defense: July 29, 2014

The dissertation of Ruonan Liu is approved.

Dean David R. Klock

College of Business Administration

Dean Lakshmi N. Reddi University Graduate School

Florida International University, 2014 


\title{
ABSTRACT OF THE DISSERTATION \\ CAN COMPENSATION COMMITTEES EFFECTIVELY MITIGATE THE CEO \\ HORIZON PROBLEM? THE ROLE OF CO-OPTED DIRECTORS
}

\author{
by \\ Ruonan Liu
}

Florida International University, 2014

Miami, Florida

Professor Stephen Lin, Major Professor

Extant research finds inconclusive evidence about the CEO horizon problem. One possibility is that compensation committees design CEO compensation in a way that discourages retiring CEOs from opportunistic earnings management and R\&D reduction. However, compensation committees dominated by co-opted directors may not be as effective as those with fewer co-opted directors in mitigating the CEO horizon problem, because directors co-opted by the CEO tend to bias their decisions in favor of the CEO. I find that compensation committees dominated by co-opted directors are associated with higher CEO compensation packages. I document R\&D reduction and accruals management in firms with retiring CEOs and compensation committees dominated by coopted directors, and find that $\mathrm{R} \& \mathrm{D}$ reduction and income-increasing accruals are less discouraged by compensation committees dominated by co-opted directors when deciding CEO compensation. I also examine the effect of boards of directors and compensation committee characteristics on CEO compensation and on mitigating the CEO horizon problem. I find that CEO compensation positively associates with CEO power, director independence, and the percentage of busy directors, and negatively 
associates with board of directors and committee size and director ownership. Moreover, I find that retiring CEOs are more likely to reduce R\&D expenditures when CEOs have more power, and director tenure is longer; retiring CEOs in firms with large boards of directors and compensation committees are less likely to manage accruals. 


\section{TABLE OF CONTENTS}

CHAPTER

PAGE

1. INTRODUCTION

2. LITERATURE REVIEW ……………...........................................................

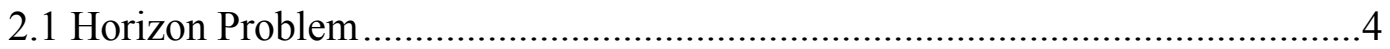

2.2 The Role of Compensation Committee.............................................................

2.3 Compensation Committee Effectiveness .....................................................13

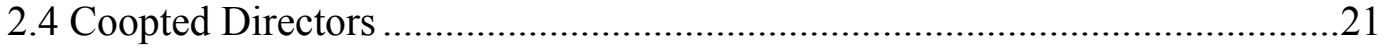

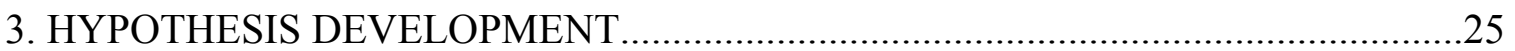

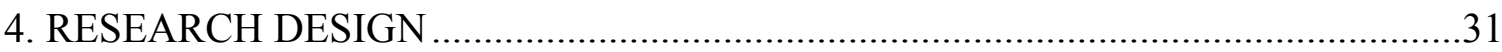

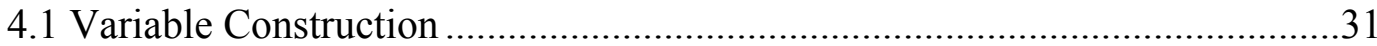

4.2 Empirical Model and Control Variables ...........................................................35

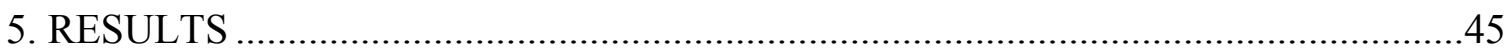

5.1 Sample

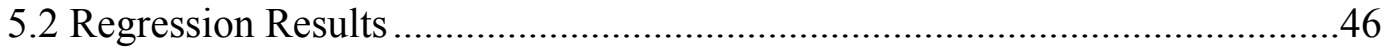

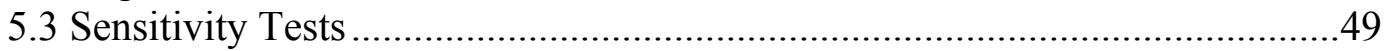

6. BOARD AND COMPENSATION COMMITTEE CHARACTERISTICS ..................52

6.1 Literature Review and Hypothesis Development ……..................................52

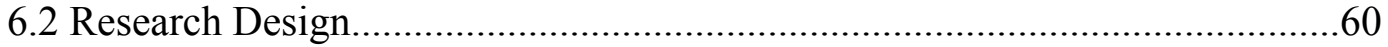

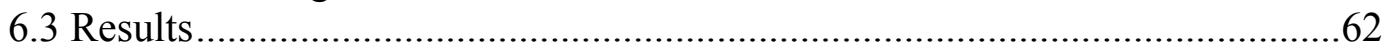

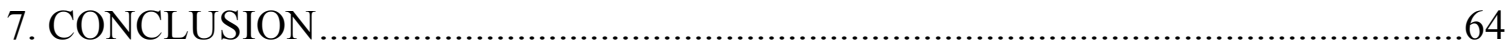

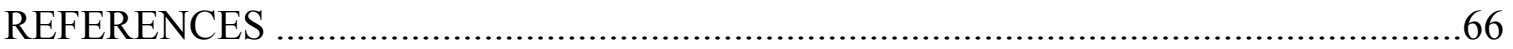

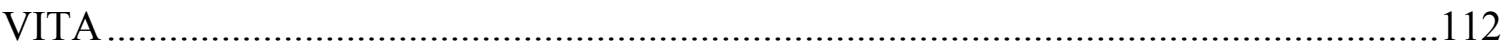




\section{LIST OF TABLES}

TABLE

PAGE

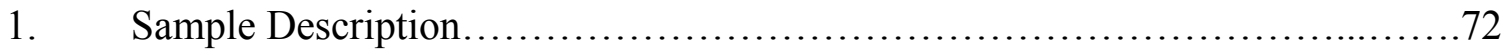

2. Regression Results: The effect of compensation committee dominated by

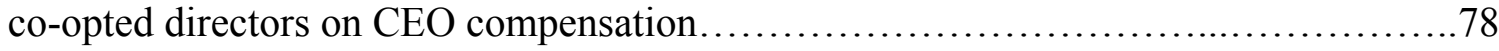

3. Descriptive Statistics and Pearson Correlations for the R\&D Test................79

4. Regression Results: The effect of whether compensation committees are dominated by co-opted directors on the association between R\&D spending and CEO horizon problem.

5. Descriptive Statistics and Pearson Correlations for the Discretionary Accruals Test

6. Regression Results: The effect of whether compensation committees are dominated by co-opted directors on the association between discretionary accruals and $\mathrm{CEO}$ horizon problem.

7. Descriptive Statistics and Pearson Correlations for the Change in CEO Compensation Test.

8. Regression Results: The effect of whether compensation committees are dominated by co-opted directors and whether CEOs are approaching retirements on the association between the change in CEO compensation and the change in R\&D.

9. Regression Results: The effect of whether compensation committees are dominated by co-opted directors and whether CEOs are approaching retirements on the association between the change in CEO compensation and the change in

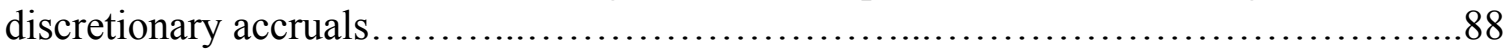

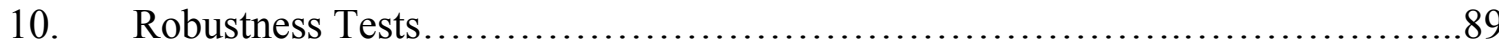

11. Pearson Correlations between the Board and Compensation Committee

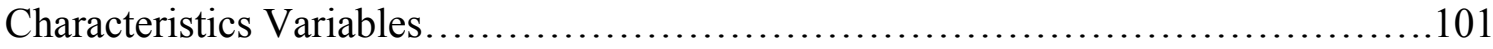

12. Factors Identified in Principal Components Analysis..........................103

13. Regression Results: The effect of board and compensation committee factors on CEO compensation 
14. Regression Results: The effect of board and compensation committee factors on the association between R\&D spending and CEO horizon problem...........105

15. Regression Results: The effect of board and compensation committee factors on the association between discretionary accruals and CEO horizon

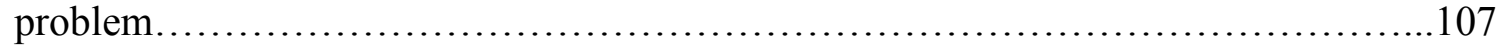




\section{INTRODUCTION}

Due to the separation of ownership and control in corporations, the interests of a CEO may deviate from the interests of the corporation's shareholders. To reduce any problems that may arise from this deviation, boards of directors typically act as monitors to reduce agency problems. For example, the compensation committee, a subcommittee of the board of directors, is responsible for designing CEO compensation packages that can align the interests between shareholders and the CEO. However, not all compensation committees are equally effective. "Co-opted directors" are defined as the directors appointed after a CEO assumes office. CEOs may use their influence over the director appointment process to co-opt directors who share some similarities or ties with them. Therefore, the co-opted directors are more likely to feel sympathetic to the CEO. In addition, the co-opted directors may be less willing to challenge their CEO since they believe they owe their board seats to him or her. As a result, the co-opted directors are less effective monitors (Coles et al., 2014). This study examines whether compensation committees' effectiveness at mitigating the CEO problem is diminished when the majority of the committee is made up by co-opted directors.

CEOs with earnings-based compensation may focus on boosting firms' short-term performance by cutting R\&D spending or engaging in accruals management. However, these opportunistic behaviors have a negative effect on a firm's value. This problem becomes more severe in CEOs' final years prior to retirement, when they are less concerned with their reputation in the job market. However, compensation committees can adjust CEO compensation to alleviate opportunistic R\&D reduction (Cheng, 2004) and opportunistic accruals management (Huson et al., 2012). If the co-opted directors are 
less effective, the compensation committees dominated by co-opted directors may be less responsive to the $\mathrm{CEO}$ horizon problem.

Using a sample of 13,606 firm-year observations for S\&P 1500 firms from 1998 to 2011, I find that CEO compensation is likely to be higher if compensation committees are dominated by co-opted directors. I find evidence of $\mathrm{R} \& \mathrm{D}$ reduction and accruals management in firms with retiring CEOs and in compensation committees dominated by co-opted directors. Further, I find that R\&D reduction and income-increasing accruals are less discouraged when determining the compensation for retiring CEOs by compensation committees that are dominated by co-opted directors.

My findings are robust to alternative measures of the compensation committee cooption and additional controls of corporate governance. CEOs' direct involvement in the director nomination process has reduced since 2004, after the NYSE Corporate Governance Section 303A, NASDAQ Rule 4350 (c), and AMEX Enhanced Corporate Governance Rules, section 805 required that nomination committees of listing firms must solely consist of independent directors. Despite this reduction in CEO direct involvement, I still find evidence that compensation committees dominated by co-opted directors are less effective in reducing CEO compensation and mitigating accruals management when CEOs approach retirement in the subsample firm-year observations during the period 2004-2011

I also investigate whether board and compensation committee characteristics are associated with $\mathrm{CEO}$ compensation and the $\mathrm{CEO}$ horizon problem using a principal

\footnotetext{
${ }^{1}$ One possibility is that the CEO can still exert indirect influence. Another explanation may be that the results are driven by the directors appointed before the year of 2004 .
} 
components analysis. I find evidence that CEO compensation positively correlates with CEO power and busy directors, while negatively correlating with director ownership. In addition, I find that both CEO power and director tenure increase the likelihood of R\&D curtailment when CEOs approach retirement. I also find that the size of the board of directors and the compensation committee affect the likelihood of accruals management when companies face a CEO horizon problem.

This study contributes in three ways. First, it reveals that although many organizations reduce their CEOs' direct involvement in the appointment process of new directors, co-opted directors are weak monitors. Coles et al. (2014) find evidence that board co-option reduces monitoring effectiveness. Since the design of CEO compensation packages is delegated to compensation committees, I focus on the role of co-opted directors on compensation committees. Second, the study adds empirical evidence to the debate of organizations' CEO horizon problem. Extant literature finds mixed evidence of the horizon problem, which may be due to the intervention of compensation committees or failure to identify when the horizon problem is the most severe. The results provide evidence that retiring CEOs engage in opportunistic R\&D cutting and income-increasing accruals management when compensation committees are less effective. Finally, the study adds to the literature on corporate governance, revealing that compensation committees play an important role in mitigating an organization's CEO horizon problem by adjusting CEO compensation. Cheng (2004) and Huson et al. (2012) discover that compensation committees intervene to mitigate an organization's CEO horizon problem by studying the association between CEO compensation and the CEO horizon problem. However, these two studies do not directly investigate compensation committees. 
Moreover, they assume all compensation committee are effective. My findings suggest that the effectiveness of compensation committees in mitigating an organization's CEO horizon problem is contingent on the quality of compensation committees.

The remainder of this study is organized as follows. Chapter 2 presents a literature review; Chapter 3 discusses the hypothesis development; Chapter 4 describes the research design; Chapter 5 reports the study's sample population and empirical results; and Chapter 6 discusses the roles of boards of directors and compensation committees in designing CEO compensation packages. The final section concludes the paper with a discussion about the significance of the findings.

\section{LITERATURE REVIEW}

\subsection{Horizon Problem}

A manager's tenure is much shorter than a firm's lifespan. When managers have shorter horizons than a firm's optimal investment horizon, managers prefer to engage projects with lower net present value but with higher current earnings, which would maximize the manager's bonus compensation. This is what is known as a horizon problem, according to Smith and Watts (1982). In other words, managers with shorter horizons are myopic; they tend to focus on increasing the firm's short-term earnings. At the beginning of their career, managers are concerned with reputation. Fama (1980) argues that managers are disciplined by the labor market because their human capital depends on the success of the firm. Therefore, CEOs care more about the firm's longterm success. However, as managers approach retirement, they have weaker career concerns and therefore the horizon problem is more severe (Gibbons and Murphy, 1992). 
Horizon problem predicts that retiring CEOs may reduce R\&D expenditures or involve in accruals management to maximize their earnings-based compensation, irrespective of the impact on the long-term benefits of the shareholders. However, extant literature finds mixed evidence of R\&D reduction and accruals management. Effective since 1974, the Financial Accounting Standards Board (FASB) require companies to expense $R \& D$ expenditures in the year that they are incurred. However, the benefits from $R \& D$ investment take years to be fully realized. Therefore, reducing $R \& D$ expenditures results in the increase of current-year accounting earnings. Dechow and Sloan (1991) finds empirical evidence of R\&D reduction prior to CEO departures for a sample of firms with large R\&D expenditures and CEO compensation based on earnings performance for firm-years from 1974 to 1988 . They suggest that CEOs reduce R\&D expenditures to increase their earnings-based compensation in the years prior to CEO departures, which is consistent with the CEO horizon problem. They find no evidence that the R\&D reductions around CEO departures are driven by poor firm performance or because the outgoing CEOs leave new investment initiatives to the incoming CEOs. Specifically, they find that CEOs who leave the company after they reach mandatory retirement age and thus anticipate departure, reduce R\&D expenditures even more. They also find similar reductions in advertising expenditures but not in capital expenditures, which do not affect earnings immediately as R\&D expenditures.

However, Murphy and Zimmerman (1993) suggest that the reductions in R\&D expenditures preceding CEO departures are driven by poor firm performance rather than horizon problems. Dechow and Sloan (1991) use a small, selected sample of firms in R\&D intensive industries. Murphy and Zimmerman (1993) examine a larger sample of 
CEO turnovers from the Forbes annual surveys during 1971 to 1989; they find that the growth rate of R\&D in the CEO's transition year (in which the old CEOs depart and the new CEOs assume office), and the CEO's last full year (the year before the transition year) is not significantly different from the three years before the CEO's last full year. They find no evidence of R\&D reductions in the transition year and the last full year after controlling for firm performance, and no evidence of $\mathrm{R} \& \mathrm{D}$ reduction preceding $\mathrm{CEO}$ turnover for the subsample of CEO turnovers unrelated to poor firm performance.

Also contrary to CEO horizon problem predictions, Gibbons and Murphy (1992) find that firms spend most on R\&D and advertising in the CEO's last year prior to retirement. They find that the level of R\&D expenditures increases, but the R\&D growth rate decreases as CEOs approach retirement. They further argue that the declining R\&D growth rate prior to retirement is not driven by the CEO horizon problem, because they do not find an increase in concurrent earnings. Butler and Newman (1989) fail to find evidence of R\&D reductions in the sample of firms with CEOs in their final year before departures compared with a matched sample of firms; they also fail to provide empirical evidence for the CEO horizon problem. They suggest that their findings do not identify when the CEO horizon problem is most severe.

Consistent with the CEO horizon problem, several studies find a negative association between CEO age or tenure and R\&D expenditures and suggest that CEOs reduce R\&D as they grow older (Barker and Mueller, 2002; Lundstrum, 2002; Naveen, 2006; Demers and Wang, 2009). However, Cazier (2011) points out the problems with these studies' research design. He identifies two factors that induce a negative bias between CEO age and R\&D expenditures in the cross-section, and thus erroneously 
support the CEO horizon problem. He finds that: 1) firms that invest more in R\&D are more likely to be delisted, so firms with CEOs who are older or have longer tenure invest less in $\mathrm{R} \& \mathrm{D}$; and 2) firms that invest more in $\mathrm{R} \& \mathrm{D}$ are more likely to hire younger CEOs. He examines CEO retirement rather than CEO age and finds that CEOs do not reduce $R \& D$ in the five years prior to their retirement.

Two recent studies, which argue that CEOs may use discretionary accruals to increase contemporaneous earnings, provide support for the CEO horizon problem (Kalyta, 2009; Antia et al., 2010). In a sample of Fortune 1000 firms from 1997 to 2006, Kalyta (2009) finds evidence of income-increasing accruals management in the years prior to CEO retirement only when the CEO's Supplemental Executive Retirement Plan (SERP) is contingent on firm performance. His findings suggest that if CEOs have performance-contingent SERPs, they have a more powerful incentive to boost firm earnings in the final years prior to retirement, in which SERPs pensionable earnings are determined. He finds negative market reaction only after the retirement of the $\mathrm{CEO}$ with a performance-contingent SERP. Antia et al. (2010) use CEO expected tenures to proxy CEO decision horizons and argue that shorter CEO horizons are associated with greater agency costs, higher information risk, and less market valuation. They find that accruals management is negatively associated with CEO decision horizons, which is consistent with horizon problems, and which leads to more accruals management.

However, several studies find inconsistencies with outgoing CEOs who boost earnings by involving income-increasing accruals management. Pourciau (1993) classifies CEO turnovers as routine turnovers in which a successor is chosen, or several contestants are identified; and non-routine turnovers, which include voluntary and 
involuntary resignations. He focused on the non-routine $\mathrm{CEO}$ turnovers and found income-decreasing accruals and write-offs before the non-routine CEO turnovers. One reason for these results is that his model fails to control for firm performance. Murphy and Zimmerman (1993) did control for firm performance, and found a significant negative association between accruals and the transition year dummy. But after further controlling for the endogeneity of CEO turnover, no significant association is found. In a sample of Australian firms, Wells (2002) does not find income-increasing accruals management prior to CEO turnover, despite whether the turnovers are routine or nonroutine. In addition, he finds no evidence of income-increasing earnings management through non-current asset sales or abnormal and ordinary items before the CEO routine and non-routine turnovers.

\subsection{The Role of the Compensation Committee}

The CEO horizon problem is one example of the conflict of interests between managers and shareholders. Shareholders cannot directly monitor managers, so they trust the board of directors with monitoring responsibilities (Fama and Jensen, 1983; Jensen and Meckling, 1976). As a subcommittee of the board of directors, the compensation committee is given the task of designing a compensation package that aligns the interests between shareholders and managers and therefore alleviates CEO horizon problem.

A firm's compensation committee is responsible for determining and overseeing

the executive compensation process. For example, Apple Inc. describes the functions of its compensation committee in a proxy statement for its 2014 annual meeting of 
shareholders as "reviewing the compensation arrangements for the Company's executive officers, including the CEO, administering the Company's equity compensation plans, and reviewing the Board's compensation. The compensation committee's authority to grant equity awards may not be delegated to the Company's management or others" (Apple Inc. Proxy Statement of 2012). Hermanson et al. (2012) interview 17 compensation committee chairs and three compensation committee members of public firms about the compensation committee process. According to the interviewees, one responsibility of the compensation committee is to oversee CEO compensation. Several studies also empirically support the important role that the compensation committee plays in designing CEO compensation (e.g., O'Reilly et al., 1988).

Accounting income is one of the performance measures used to determine CEO compensation (Lambert and Larcker, 1987). Prior research provides evidence that when compensation committees determine CEO compensation based on accounting income, they treat income items differently. In fact, they sometimes shield certain income items, for example, restructuring charges (Dechow et al., 1994; Adut et al., 2003), and even reward CEOs for certain expenditures that reduce income (Cheng 2004). More importantly, the different treatments are based on individual circumstances. Balsam (1998) examines the association between different components of earnings and CEO cash compensation, and finds that when including CEO cash compensation, the weight on discretionary accruals is relatively lower than the weight on nondiscretionary accruals, which in turn is lower than the weight on operating cash flows. He also shows that the weight of positive discretionary accruals is higher than negative discretionary accruals, indicating that compensation committees reward CEOs for positive discretionary accruals 
while avoiding punishing CEOs for negative discretionary accruals. He further documents that compensation committees reward CEOs for positive discretionary accruals even more if the firms need to meet an earnings target. Gaver and Gaver (1998) examine the weight of above-the-line earnings and below-the-line earnings when including CEO cash compensation. Their findings suggest that above-the-line and belowthe-line gains are included while above-the-line and below-the-line losses are excluded from CEO cash compensation. They separately examine unusual transactions, extraordinary transactions, and discontinued operations, for which gains are included while losses are excluded from CEO cash compensation.

In a sample of firms reporting restructuring charges between 1982 and 1989, Dechow et al. (1994) specifically examine whether compensation committees shield CEO cash compensation from restructuring charges, which are reported as a component of income from continuing operations. They argue that restructuring charges can enhance firm value, but those costs reduce current earnings. Their findings suggest that CEO compensation is shielded from restructuring charges, especially when the restructuring charges are not frequent and the $\mathrm{CEO}$ has a shorter expected horizon. This is consistent with the compensation committees' adjustment for the income-decreasing effects of restructuring charges. Following Dechow et al. (1994), Adut et al. (2003) find that compensation committees partially shield CEO compensation from restructuring charges after controlling for growth in CEO compensation for their sample between 1982 and 1997, and the degree of shielding varies depending on the CEO tenure and how close the current restructuring charge is to the prior restructuring charge. Generally, Adut et al. (2003) find less shielding if the restructuring charges are more likely to be opportunistic 
in nature. Duru et al. (2002) attempt to explain the reason of this shielding by analyzing the agency model. Their analysis suggests that if evaluated based on income with no adjustments, managers have no incentives to invest in value-enhancing but incomedecreasing activities. In addition, they provide empirical evidence that compensation committees shield recurring expenditures, such as $R \& D$ and advertising expenditures, and $R \& D$ expenditures are more filtered than advertising expenditures from CEO cash compensation.

Compensation committees treat CEOs differently, providing various incentives for CEOs. Balsam (1998) reveals that when a CEO's compensation is tied closely to earnings, then the $\mathrm{CEO}$ is more likely to use discretionary accruals to boost earnings. Cheng (2004) finds that the association between changes in R\&D spending and changes in value of CEO annual option grants is significantly positive when the CEO approaches retirement and when the firm faces a small decline in earnings and a small loss, but insignificant when there is no horizon problem or myopia problem. Cheng's (2004) findings indicate that compensation committees mitigate opportunistic $R \& D$ reduction by rewarding (penalizing) CEOs for increasing (reducing) $R \& D$ expenditures when a firm is faced with a CEO horizon problem and myopia problem. Huson et al. (2012) find that compensation committees are able to place a lower relative weight on the positive change in discretionary accruals compared with other components of earnings when setting CEO cash pay during the years before CEO voluntary turnovers. They claim that compensation committees allow income-increasing discretionary accruals to increase CEO compensation the same way as other earnings components during non-terminal years, since the reverse feature of accruals will reduce CEO compensation in the subsequent 
years. However, when fewer possibilities reverse accruals, compensation committees intervene to reduce the relative weight on the increase of discretionary accruals when they decide a CEO's cash compensation in his or her terminal years. They also show that Selling, General, and Administration (SG\&A) expenditures are at least partially shielded from CEO compensation in the non-terminal years, but not shielded at all in the terminal years. Their results are consistent with the idea that compensation committees generally encourage spending in SG\&A but less so during a CEO's terminal years.

Collectively, the prior literature shows that compensation committees use discretion to adjust $\mathrm{CEO}$ compensation to mitigate adverse incentives for CEOs.

\subsection{Compensation Committee Effectiveness}

Firms that separate ownership and control create a divergence in the interests between shareholders and managers (Jensen and Meckling, 1976). Demsetz (1983) argues that compensation contracts can adequately align the interests of managers with those of shareholders. Prior studies provide support that compensation committees are able to alleviate the CEO horizon problem (Cheng 2004; Huson et al., 2012). However, compensation committees are not equally effective monitors. Uzun et al. (2004) note that the presence of a compensation committee is positively associated with the likelihood of fraud. They claim that compensation committees are "systematically dysfunctional" and responsible for "lucrative stock options" (Uzun et al., 2004).

The monitoring effectiveness of compensation committees is affected by their characteristics (e.g. Sun and Cahan, 2012; Sun and Cahan, 2009; Sun et al., 2009; Bebchuk et al., 2010; Collins et al., 2009; Laksmana, 2008; Nelson et al., 2010; Uzun et al., 2004). Sun and Cahan (2012) argue that six compensation committee characteristics 
affect compensation committee quality: the proportion of co-opted directors, the proportion of senior directors, the proportion of directors who are CEOs of other companies, the proportion of directors with block shareholdings in the company, the proportion of directors who have three or more board seats, and the size of the compensation committee. They conduct a principal components analysis of these six characteristics and develop a compensation committee quality measure. They show that their compensation committee quality measure is negatively associated with CEO tenure, institutional holdings, growth opportunities, and firm size. Two other studies (Sun et al., 2009; Sun and Cahan, 2009) use the same measure of compensation committee quality to examine whether the compensation committee quality affects the pay-for-performance. Sun et al. (2009) investigate a sample of 474 firms with compensation committees composed solely of independent directors in 2001, when compensation committee independence was not a mandatory requirement. They suggest that a compensation committee's quality has a positive effect on the relationship between a CEO's stock option grants and the firm's future performance, measured as future operating performance and future stock returns. They also separately examine the effect of the six compensation committee characteristics on the pay-for-performance sensitivity. They find consistent evidence that the proportion of co-opted directors, senior directors, CEO directors, and busy directors affect the pay-for-performance, but find weak evidence for director shareholdings and size of the committee. Sun and Cahan (2009) show that the relationship between $\mathrm{CEO}$ cash compensation and accounting earnings increase as a compensation committee's quality increases. Moreover, the effect of a compensation committee is less positive in firms with high growth or incurring losses, which is 
consistent with the idea that high growth firms and loss-bearing firms rely on other performance measures than accounting earnings. The findings of those two studies suggest that high-quality compensation committees can design better compensation packages that align a CEO's incentives with the firm's economic benefits.

Bebchuk et al. (2010) examine the association between corporate governance and the timing of CEO stock options. They document that a compensation committee consists of independent directors and at least one blockholder who is less likely to grant CEO options opportunistically at the lowest price of the month. Similarly, Collins et al. (2009) document a negative association between the likelihood of backdating CEO stock option grants and having an outsider who owns at least five percent of outstanding shares on the compensation committee.

Several studies also claim that compensation committee characteristics to relate to the disclosure transparency of executive compensation (Laksmana, 2008; Nelson et al., 2010). Managers are generally inclined to avoid the scrutiny from shareholders and therefore reluctant to disclose their compensation, while better corporate governance leads to more disclosures. Laksmana (2008) suggests that disclosure transparency of compensation practices is positively associated with compensation committee independence, meeting frequency, and size. Using Australian data, Nelson et al. (2010) find that firms with more independent and effective compensation committees are more likely to disclose sensitive information related to executive stock options. They also use a principal components analysis to reduce three compensation committee characteristics, including committee size, number of committee meetings, and proportion of independent 
directors on the committee, into one factor to proxy for compensation committee independence and effectiveness.

A growing body of literature has examined whether the independent status of compensation committee directors affects how effective the compensation committee protects shareholders from excessive CEO pay (Daily et al., 1998; Chhaochharia and Grinstein, 2009; Sapp, 2008; Conyon, 2006; Anderson and Bizjak, 2003; Vafeas, 2003b; Conyon and Peck, 1998; Newman and Mozes, 1999). Despite the general belief that better governance can oversee CEOs' rent extraction more effectively, the literature finds little evidence that a more independent compensation committee leads to lower CEO compensation. Daily et al. (1998) investigate whether a compensation committee with a higher proportion of "captured directors" tends to increase CEO pay and CEO noncontingent pay. To define a director as being "captured," Daily et al. (1998) uses three measures: whether the director is affiliated with the CEO of the firm, whether the director is appointed during the tenure of an incumbent $\mathrm{CEO}$, and whether the director is a CEO of another company. They find no significant association between CEO pay and the proportion of affiliated directors, or the proportion of CEO directors on the compensation committee. Chhaochharia and Grinstein (2009) examine the change in CEO compensation when firms make changes to the composition of their boards of directors in compliance with a list of board requirements set by the SEC in 2002. They find no evidence that the requirements imposed on independent compensation committees are associated with a reduction in CEO compensation, although they document a negative association between the requirement which states that the majority of the board of directors must be independent and the change of CEO compensation. This infers that the 
board's independence is more important than the compensation committee's independence when determining CEO compensation.

Conyon (2006) shows that CEO pay is not affected by the presence of affiliated directors on compensation committees. He uses the Investor Responsibility Research Center (IRRC) database and defines directors as "affiliated" if they are either "Employee" or "Linked." According to IRRC, a linked director is "is linked to the company through certain relationships, and whose views may be affected because of such links" (IRRC), for example a former employee. Similarly, Newman and Mozes (1999) classify inside directors as former employees of the focal firm, employees of a firm who have the focal firm's CEO on their board of directors, current employees of a firm conducting material business with the focal firm, or interlocking directors. Using data from 1992, they conclude that CEO pay is not higher in firms with compensation committees that include insiders, than those whose compensation committees are composed solely of outsiders. Anderson and Bizjak (2003) classify directors who are not current or formal employees, are not immediate family members, or who have no business ties with the firm as outside directors. They find little evidence that CEO pay is higher when the percentage of outside directors on a compensation committee is lower, or when the CEOs are members of their compensation committee. Vafeas (2003b) defines insiders as directors who are or were firm executives or employees of subsidiaries. He finds no evidence among a sample of 271 firms from 1991 to 1997 that CEO pay is related to the presence or percentage of insiders on the compensation committee.

Two studies find a positive association between compensation committee independence and CEO compensation. In a sample of Canadian firms, Sapp (2008) finds 
that the number of independent directors on a compensation committee is positively associated with CEO pay, which is contrary to his prediction. The author argues that this finding may be due to the definition of "independence." He also finds that a higher proportion of directors who are CEOs of other companies and a lower proportion of financial experts leads to higher CEO compensation. In their sample of U.K. companies, Conyon and Peck (1998) also document an unanticipated positive association between the proportion of nonexecutive directors on the remuneration committee and management pay.

Some of the above-mentioned studies (Anderson and Bizjak, 2003; Newman and Mozes, 1999; Vafeas, 2003b) and a number of other studies (Capezio et al., 2011; Conyon and Peck, 1998) have addressed whether compensation committee independence affects CEO pay-for-performance. Capezio et al. (2011) examine a sample of Australian companies and find no evidence that a compensation committee dominated by nonexecutive directors improves CEO pay-for-performance. Anderson and Bizjak (2003) find only marginal evidence that the proportion of outside directors on a compensation committee is positively related to CEO equity-based pay; they also find no evidence that the pay mix or pay-for-performance in firms with a compensation committee composed only of outsiders is different than those with a less independent compensation committee. Overall, they do not provide strong support that the proportion of outsiders in a compensation committee increases CEO incentives. Newman and Mozes (1999) find no significant difference between the pay-for-performance in firms with compensation committees that have no insiders, and firms with compensation committees with insiders when the firm's return is positive. However, they find a significant difference when the 
firm's return is negative, although the pay is not related to performance, despite whether compensation committees consist of insiders or not. Their findings suggest that compensation committees with insiders reward CEOs for a favorable performance the same way a compensation committees with no insiders would, but those with insiders are more likely to shield CEO compensation from unfavorable performance. In addition, Conyon and Peck (1998) show that the pay-for-performance is greater in firms with remuneration committees with a higher proportion of nonexecutive directors. Vafeas (2003b) provides evidence that before the compensation disclosure rules of the SEC in 1992, insider participation in compensation committees led to more non-contingent pay, but less contingent pay and thus less risk for CEOs.

Extant research about compensation committees' independence reflects, to some degree, the public's concern that insider participation in compensation committees may compromise its independence and may lead to an excessive compensation package that CEO's do not deserve. Also motivated by the public's concern, regulations have become stricter regarding compensation committees' degree of independence over the years. In 1992, the SEC adopted provisions to encourage directors without ties to the firm to be more responsible for establishing executive pay by increasing disclosure requirements when corporate insiders serve on compensation committees. The 1993 congressional tax code stipulates that compensation committees must be composed solely of two or more outside directors, or any performance-based executive pay in excess of $\$ 1$ million is not tax deductible. Approved in 2003, the New York Stock Exchange (NYSE) and NASDAQ require listed firms' compensation committees to consist solely of independent directors. According to NYSE section 303A, an independent director is defined as a director with 
no material relationship with the listed company, directly, or as a partner, shareholder, or officer of an organization that has a relationship with the company. In addition, NYSE section 303A specifically states that a director is not independent if within three years, the director has been an employee, an executive officer, or an immediate family member of the executive officer within the last three years; if the director or his/her family has received more than $\$ 120,000$ direct compensation, except for directorship or prior service in the firm; if the director or his/her family has been an executive officer of another company in which any current executive officers serve or served on the focal company's compensation committee; and, if the director is a current employee or family member of the current executive officer of a company that does business with the focal company at an amount exceeding $\$ 1$ million, or $2 \%$ of the company's consolidated gross revenues. The Dodd-Frank Act of 2010 requires each member of a compensation committee in a public company to be independent if: the compensation committee member's source of compensation is received from the company, or the compensation committee member is affiliated with the company or its subsidiary.

However, the literature has not determined conclusively whether a compensation committee's independence affects CEO pay or pay-for-performance. One explanation for the mixed findings may be because it is hard to measure the real independence of a compensation committee. According to Hermanson et al. (2012), many compensation committee directors interviewed had previous professional or personal connections to CEOs at the time they were appointed; however, they are independent if judged by the stock exchange listing standards. Likewise, Bebchuk et al. (2005) allege that even directors who satisfy the legal requirement for independence may not truly be 
independent, because the $\mathrm{CEO}$ controls the director nomination process and maintains social relations with directors. O'Reilly and Main (2007) point out two important social psychological effects: reciprocity and social influence. Under reciprocity, directors may feel obligated to the CEO if they believe they get their board seats, to some degree, thanks to the CEO. Under social influence, directors sympathize with the CEO, especially if they share more similarities with the CEO. They provide empirical evidence that the board of directors is more prone to reciprocity and social influence tends to be more generous on CEO pay decisions.

\subsection{Co-opted Directors}

Coles et al. (2014) argue that directors appointed during the tenure of an incumbent CEO (i.e., co-opted directors) are less independent. Consistent with their predictions, they find that the proportion of co-opted directors on the board of directors is negatively associated with turnover-to-performance sensitivity, and positively associated with CEO pay and investment, after controlling for the proportion of outsiders on the board. Their findings infer that co-opted directors are more sympathetic to CEOs, as evidenced by their tendency to keep CEOs who have performed poorly, to be generous about CEO pay, and to agree to CEOs' over-investment. They also argue that non-coopted independence can better explain the independent status of the board, which is the proportion of directors who are outsiders and appointed before the CEO assumes office. They document that non-co-opted-independence increases CEO turnover-to-performance and pay-for-performance, while decreasing CEO pay and investment.

Similarly, Lambert et al. (1993) find that the percentage of outside board members appointed by the CEO increases the level of executive compensation; they 
investigate the confidential compensation data at different organization levels, including plant manager, divisional CEO, group CEO, and corporate CEO. Core et al. (1999) also find a positive association between CEO compensation and the percentage of outside directors who are appointed after the CEO takes office, indicating that CEOs' involvement in the nomination of new directors increases their own pay.

Wade et al. (1990) and Collins et al. (2009) reveal a lack of dependence among co-opted directors. They find that as the percentage of directors appointed during an incumbent CEO's tenure on the board increases, the CEO is more likely to be granted a golden parachute, indicating that CEOs have more influence over the board concerning their compensation package if the board is composed of more co-opted directors. Collins et al. (2009) find that a higher proportion of co-opted directors on the board increases the probability of backdating CEO stock option grants.

Prior studies focus on the boards' co-options, while only one study (Daily et al., 1998) examines the compensation committee co-option and provides rather weak evidence that the compensation committee co-option increases CEO compensation. Daily et al. (1998) find a positive association between the proportion of co-opted directors on the compensation committee and CEO total pay and non-contingent pay in one of three years for their sample from 1992 to 1994.

Two underlying reasons may have contributed to the findings of the above studies. First, CEOs exert considerable influence on the director nomination process. It has been criticized that directors are selected by the very CEOs whom they are supposed to monitor. CEOs propose the slate of directors, and the slate is almost always voted in by the shareholders (Hermalin and Weisbach, 1998). Cai et al. (2009) also show that the 
differences in shareholders' votes for directors are small. DeAngelo et al. (1989) document that even when shareholders disagree with CEOs in a proxy fight, the odds for shareholders to win the board seat are only about one-third. Mace (1971) interviewed CEOs and directors, and found that CEOs exert considerable influence on the director nomination process. With power over the nomination of new directors, CEOs can negotiate more favorable compensation contracts. For example, Grinstein and Hribar (2004) document that CEOs receive a higher mergers and acquisitions (M\&As) bonus when they sit on the nomination committee, and when they are also the board chair.

After the Sarbanes Oxley Act of 2002, a CEO's direct involvement in the director nomination process has significantly reduced. For example, NYSE Corporate Governance, section 303A, which was approved on June 30, 2003, requires listed companies to have a nominating committee composed entirely of independent directors. A CEO can still exert informal or indirect influence over the nomination, however. NASDAQ Rule 4350 (c), and AMEX Enhanced Corporate Governance Rules, section 805, have similar requirements. However, CEOs can still exert indirect influence on the appointment of directors.

Studies focusing on CEOs' influence in the director nomination process suggest that CEOs favor directors who are sympathetic (Finkelstein and Hambrick, 1989), who are similar to themselves (Westphal and Zajac, 1995; Hwang and Kim, 2009) or who are gray directors (Shivdasani and Yermack, 1999) to gain more board support. Finkelstein and Hambrick (1989) allege that the longer a CEO stays in a company, then he or she may appoint more sympathetic directors to the board of directors. Westphal and Zajac (1995) allege that CEOs prefer directors who share a similar functional background, age, 
education level, and outsider/insider status, since those directors are less likely to disagree with CEOs. They consider the director nomination process to be a power battle between CEOs and the existing board, in which more CEO power leads to the appointment of directors who are more similar demographically to the CEO. Meanwhile, directors who are more similar to the board will be appointed if the board is more powerful relative to the CEO. Their findings generally support their predictions. They also find that the change in the similarity between the CEO and the board is positively associated with the change in a CEO's total compensation; it is negatively associated with the change in a CEO's contingent compensation, indicating that by appointing a more similar director, CEOs may increase their total pay while decreasing their exposure to risk. Similarly, Hwang and Kim (2009) find evidence that the number of socially linked directors increases as a new CEO's tenure at the firm progresses, suggesting that CEOs select directors who share similar ideas and views, or who have certain social ties to the CEO. O'Reilly et al. (1988) observe a significant association between the salary levels of compensation committee directors and CEO compensation. They suggest that CEOs may select directors who are highly paid current or retired CEOs of other companies so that those directors use their own compensation as a reference when they determine $\mathrm{CEO}$ compensation. But they fail to establish the causality because they do not have the data for the director's appointment date.

Shivdasani and Yermack (1999) reveal that when a CEO serves on the nomination committee or there is no separate nomination committee, companies appoint a higher number of gray directors and fewer independent directors. Their results indicate that 
when CEOs are involved in the director nomination, they select directors more subjective to their control.

The second reason why co-opted directors are less independent is because they may feel as if they owe their board seats to the CEO (Dailey et al., 1998); they are likely to offer their gratitude by biasing for the CEO (Bebchuk et al., 2002; Bebchuk et al., 2005). In other words, co-opted compensation committee directors may put CEO interest over their fiduciary responsibility to shareholders.

\section{HYPOTHESIS DEVELOPMENT}

Prior studies investigating firms' CEO horizon problem focus on two opportunistic behaviors that $\mathrm{CEO}$ exhibit to maximize their earnings-based compensation. The first is opportunistic R\&D reduction, and the second is opportunistic accruals management. Although career concerns mitigate a firm's CEO horizon problem early in the CEO's career, career concerns may be subjected to the CEO horizon problem when CEOs approach retirement. To alleviate this horizon problem, compensation committees can take an active role to adjust CEO compensation to induce the right incentives.

Literature examining the association between CEO compensation and the components of earnings suggest that compensation committees intervene to adjust CEO compensation. For example, according to Cheng (2004), a positive association between change in R\&D expenditures and change in CEO compensation suggests that compensation committees reward investment in R\&D and punish opportunistic reduction in $\mathrm{R} \& \mathrm{D}$ expenditures. He finds no association between $\mathrm{CEO}$ compensation and $\mathrm{R} \& \mathrm{D}$ 
expenditures, which is consistent with prior literature that R\&D expenditures are generally shielded from CEO compensation. However, he finds a positive association between change in $\mathrm{R} \& \mathrm{D}$ expenditures and change in CEO stock option compensation when CEOs approach retirement, which suggests that compensation committees penalize CEOs for opportunistic R\&D reduction in a CEO's final years before retirement. Using a sample of 476 firms in which CEOs retired or departed voluntarily, Huson et al. (2012) investigated the effect of the horizon problem on the association between positive change in discretionary accruals and CEO cash compensation. They document that the relative weight of positive change in discretionary accruals reduces significantly in the year of CEO turnover, and in the year before. They suggest that although an increase in discretionary accruals is treated the same way as other earnings components in CEOs' non-terminal years, the increase receives less weight compared to other earnings components when CEOs are in their terminal years. This indicates that compensation committees restrain CEOs from opportunistic income-increasing accruals management prior to CEO departures. To some degree, these studies are in line with the optimal contracting theory that compensation contracts are optimally designed to motivate the managers to act in the best interests of shareholders (Holmstrom, 1979). However, this literature reveals the roles of compensation committees in mitigating horizon problems without investigating compensation committees directly.

The effectiveness of compensation committees can be different between firms. Cheng (2004) separately investigates firms with opportunistic R\&D reductions when CEOs approach retirement, and firms without such reductions. He only finds a significant association between changes in CEO stock option grants and changes in R\&D 
expenditures in firms without opportunistic R\&D reductions, but not in other firms. This brings up the question: why do some firms successfully adjust CEO compensation and thus mitigate horizon problems, while others don't? For one thing, firms' different reactions to CEO horizon problem may be due to the different degree of co-option among compensation committees.

Under the managerial power theory, because managers use their influence to extract rents from the board of directors, compensation contracts always deviate from the optimum (Finkelstein, 1992). In other words, to control the compensation contracting process, CEOs need agreeable or loyal directors on the board of directors. Therefore, they tend to appoint directors who are sympathetic. These co-opted directors feel obligated to their CEOs and as a result make decisions favorable to the CEOs. In a recent study, Coles et al. (2014) provide empirical evidence that board co-option decreases monitoring effectiveness. They document that CEO pay and investment are positively related to board co-option, while CEO turnover to performance sensitivity is negatively related to board co-option. They further suggest that the proportion of co-opted directors who are outsiders increases CEO pay, while the proportion of co-opted directors who are insiders is not related to CEO pay or CEO pay-for-performance, inferring that even outside directors' independence, if co-opted by CEOs, are damaged. Furthermore, they propose that the proportion of outsiders who are not co-opted by CEOs is a more 'incisive' measure for board monitoring because it increases CEO turnover to performance sensitivity, and to pay-for-performance sensitivity, while reducing CEO pay and investment. Their findings are consistent with the managerial power theory, which states that CEOs use their power to gain control over the board. Social and psychological 
factors keep directors from real independence. Directors who are co-opted by the incumbent $\mathrm{CEO}$ may feel obligated to the $\mathrm{CEO}$, and as a result, are less willing to challenge the CEO.

Coles et al. (2014) examine entire boards of directors. It is not clear that the increased CEO pay and reduced CEO pay-for-performance is driven by the co-option of compensation committees or the co-option of the board. Similarly, Lambert et al. (1993), Wade et al. (1990), and Collins et al. (2009) also focus on the co-option of the board. Daily et al. (1998) examine the co-option of compensation committees. However, they document little empirical evidence that the co-option of compensation committees is positively associated with CEO non-contingent pay in 1992, but no evidence for 1993 or 1994. They find no association between the co-option of compensation committees and CEO contingent pay or CEO total pay.

Excessive CEO payment has been under fire. Since the authority to set CEO compensation is delegated to compensation committees, if co-option decreases the monitoring effectiveness of the compensation committee, then the co-option may increase CEO compensation. Therefore, I predict:

H1: CEO compensation is positively associated with the co-option of compensation committees.

Prior literature examining the CEO horizon problem found mixed evidence of opportunistic R\&D reductions and opportunistic accruals management. One explanation for the lack of consistent evidence in support of the CEO horizon problem may be due to the intervention of compensation committees. Effective compensation committees should predict CEO horizon problem and mitigate CEOs' opportunistic behavior. However, if 
compensation committees dominated by co-opted directors are less effective monitors, they are less likely to alleviate CEO opportunistic behaviors. Therefore, I predict:

H2a: $R \& D$ expenditures are negatively associated with the CEO horizon problem when compensation committees are dominated by co-opted directors.

H2b: Discretionary accruals are positively associated with the CEO horizon problem when compensation committees are dominated by coopted directors.

CEOs' compensation packages are an important means of resolving the conflict between shareholders and the CEO (Watts and Zimmerman, 1978?). For example, compensation packages can be used to prevent a CEO's opportunistic behaviors. If R\&D expenditures are shielded from CEO compensation, CEOs' incentives to cut R\&D expenditures will be alleviated. Cheng (2004) finds a positive association between change in $\mathrm{R} \& \mathrm{D}$ and change in $\mathrm{CEO}$ stock options when a firm is confronted with a CEO horizon problem, indicating that compensation committees reward R\&D investment and punish R\&D reduction when CEOs have incentives to act opportunistically. According to interviews conducted by Hermanson et al. (2012), compensation committees communicate with CEOs about their compensation packages. CEOs who are aware that R\&D expenditures are shielded or rewarded should refrain from opportunistic R\&D cutting. Compensation committees who are aligned with shareholders' best interests are more likely to predict CEO horizon problem and adjust CEO compensation accordingly. Therefore, effective compensation committees should shield or reward an increase in R\&D in a CEO's final years before his or her retirement, to mitigate the CEO horizon 
problem. However, compensation committees dominated by co-opted directors may be less responsive to the CEO horizon problem or less willing to punish CEOs for R\&D reduction. As a result, $R \& D$ expenditures are less shielded from CEO compensation, or $R \& D$ reduction is punished less severely, so that as CEOs reduce $R \& D$ expenditures, their compensation increases. Therefore, I predict:

H3a: Changes in CEO compensation are more negatively associated with changes in $R \& D$ expenditures when firms have a CEO horizon problem and compensation committees are dominated by the co-opted directors.

The CEO horizon problem is also alleviated if income-increasing discretionary accruals are weighted less when deciding CEO compensation. Effective compensation may reduce the association between CEO compensation and income-increasing discretionary accruals when firms are faced with the CEO horizon problem. However, compensation committees dominated by co-opted directors may be less effective in adjusting the association between CEO compensation and income-increasing discretionary accruals in the final years before CEO retirement, and as a result, when CEOs are involved in income-increasing accruals management, their compensation increases. Therefore, I predict:

H3b: Changes in CEO compensation are more positively associated with income-increasing discretionary accruals when firms are confronted with the CEO horizon problem and compensation committees are dominated by the co-opted directors. 


\section{RESEARCH DESIGN}

\subsection{Variable Construction}

\section{Compensation Committee Co-option}

Following Coles et al. (2014), I measure co-option CC_COOPTION as the percentage of co-opted directors on the compensation committee. The effect of co-opted directors on CEO compensation decisions may not be linear. Therefore, I define co-opted directors as directors appointed after the incumbent CEO takes office. I define compensation committees dominated by co-opted directors COOPTED_CC as a dummy variable that equals one if the majority of directors on the compensation committee are co-opted directors, and zero otherwise.

\section{Horizon Problem}

I follow Kalyta (2009) and define Horizon as a dummy variable that equals one if CEOs are in any of the final two years prior to their retirement, and zero otherwise. The first reason I focus on CEO retirement rather than on CEO turnovers is because retiring CEOs have more severe horizon problems since they are less concerned with their reputation on the labor market (Gibbons and Murphy, 1992). Also, minus unplanned CEO turnover, CEOs can plan their retirement. Most companies have a specified retirement age (Sundaram and Yermack, 2007) $)^{2}$. CEOs who are able to predict their departures have more chances to cut R\&D or manage accruals (Dechow and Sloan, 1991). I first identify CEO turnovers, and then remove the CEOs who leave their firm at an age

\footnotetext{
${ }^{2}$ Sundaram and Yermack (2007) suggest that companies expect CEOs to retire at the specified age. If CEOs leave early, they will not obtain the full value of the pension benefit. If CEOs stay beyond the specified retirement age, they forfeit the right to pension benefits that would otherwise have been collected by retiring.
} 
younger than 63, consistent with Kalyta (2009). RiskMetrics identifies the reason for CEO departures, although this information is missing for most firms. Out of 303 retirements identified by RiskMetrics, the retirement age ranges from 46 to 82 . The average retirement age is 64.6, and the median is 64.5. 77 CEOs retired at 64, 61 CEOs retired at 65, $55 \mathrm{CEOs}$ retired at 60, and $52 \mathrm{CEOs}$ retired at 63 . I also assume the retirement age as 60,61 , and 62 , and the results are similar. I also impose another criterion that a retired CEO must have held the position for more than three full years to eliminate the potential effect of the horizon problem associated with the departure of the previous CEO, similar to prior studies (Kalyta, 2009; Huson et al., 2012). The predeparture years are two years before CEO retirement in this study.

\section{CEO compensation}

Total CEO compensation is defined as the sum of a CEO's salary, bonus, other annual compensation, restricted stock grants, long-term incentive payouts, all other compensation, and value of option grants (EXECUCOMP data item TDC1). CEO cash compensation includes salary and a bonus. CEO long-term compensation is measured as the sum of restricted stock grants, value of option grants, and long-term incentive payouts. I use the natural logarithm of all the compensation measures to reduce heteroskedasticity, similar to prior studies (Cheng, 2004; Huson et al., 2012). I also adjust all the compensation measures to 2003 dollars, using the Consumer Price Index. My findings are robust without the adjustment.

I examine cash compensation, total compensation, and long-term compensation separately, because compensation committees may use different compensation 
components to mitigate opportunistic R\&D curtailment and accruals management. Dechow and Sloan (1991) show that equity-based compensation can be used to alleviate R\&D reduction. Cheng (2004) documents that compensation committees adjust CEO stock options that are vested in future years when R\&D investments benefit the firm. They suggest stock options are used rather than cash compensation to guarantee the quality of R\&D investments. However, Huson et al. (2012) provide evidence that compensation committees adjust $\mathrm{CEO}$ cash compensation to prevent accruals management. They do not test long-term based compensation; nevertheless, they claim that most of CEO supplemental employee retirement plans (SERPs) are based on CEO cash compensation during CEOs' final years before retirement, and Kalyta (2009) only finds accruals management in firms with a retiring CEO whose SERP depends on firm performance.

\section{Discretionary accruals}

I measure discretionary accruals using the forward-looking discretionary accruals model developed by Dechow et al. (2003). Specifically, I define total accruals $T A_{i, t}$ as the difference between earnings before extraordinary items and cash flows from operations, scaled by total assets at the beginning of year $t$. I then estimate the following model cross-sectionally by industry ${ }^{3}$ and year.

$$
\begin{aligned}
T A_{i, t}= & \alpha+\beta_{I}\left((1+k) \Delta S A L E_{i, t}-\triangle R E C_{i, t}\right)+\beta_{2} P P E_{i, t}+\beta_{3} A_{i, t-1}+ \\
& \beta_{4} G R \_S A L E_{i, t}+\varepsilon_{i, t}
\end{aligned}
$$

\footnotetext{
${ }^{3}$ Industry is defined by two-digit SIC code.
} 
Where $k^{4}$ is the slope coefficient from the regression of change in accounts receivable on change in sales for each industry and year group, and captures the expected change in accounts receivable for a given change in sales. $\triangle S A L E_{i, t}$ is the change in sales from the year $t-1$ to the year $t$ scaled by total assets at $t-1, \triangle R E C_{i, t}$ is the change in net receivables from the year $t-1$ to year $t$ scaled by total assets at $t-1, P P E_{i, t}$ is the gross property plants and equipment in year $t$ scaled by total assets at $t-1, A_{i, t-1}$ is total assets at the beginning of year $t$, and GR_SALE $E_{i, t-1}$ is the sales growth from year $t$ to year $t+1$.

Nondiscretionary accruals for each firm-year observation are calculated by applying industry and year-specific parameters $\beta_{1}, \beta_{2}$, and $\beta_{3}$ as follows:

$$
\begin{aligned}
N D A_{i, t}= & \alpha+\beta_{I}\left((1+k) \triangle S A L E_{i, t}-\triangle R E C_{i, t}\right)+\beta_{2} P P E_{i, t}+\beta_{3} A_{i, t-1}+ \\
& \beta_{4} G R \_S A L E_{i, t}
\end{aligned}
$$

Discretionary accruals are then estimated by subtracting the predicted level of nondiscretionary accruals $(N D A)$ from total accruals $(T A)$, as follows:

$$
\text { Discretionary accruals } s_{i, t}=T A_{i, t}-N D A_{i, t}
$$

\subsection{Empirical Model and Control Variables}

Hypothesis $H 1$ predicts that CEO compensation is higher if the compensation committee is dominated by co-opted directors. Moreover, a CEO is more likely to enjoy increased compensation in the final years before retirement if the compensation committee is dominated by co-opted directors. To test $H 1$, I run the model (2), as specified below:

$$
\begin{aligned}
& \ln C E O{ }_{-} P A Y_{i, t}=\alpha+\beta_{1} C O O P T E D \_C C_{i, t}+\beta_{2} S_{I Z E_{i, t}}+\beta_{3} R O A_{i, t}+ \\
& \beta_{4} C E O \_T E N U R E_{i, t}+\beta_{5} C E O \_O W N E R S H I P_{i, t}+
\end{aligned}
$$

\footnotetext{
${ }^{4} \mathrm{~K}$ is restricted to be between 0 and 1, following Dechow et al. (2003).
} 


$$
\begin{aligned}
& \beta_{6} C E O \_C H A I R_{i, t}+\beta_{7} B_{-} I N D E P E N D E N C E_{i, t}+\beta_{8} B \_S I Z E_{i, t}+ \\
& \beta_{9} B_{-} \text {FEMALE } E_{i, t}+G_{-} I N D E X+Y E A R+\varepsilon_{i, t}
\end{aligned}
$$

Where COOPTED_CC is an indicator variable that equals one if the majority of compensation committee directors are co-opted by the incumbent CEO, and zero otherwise. Hypothesis $H 1$ predicts the coefficient $\beta_{1}$ to be positive and significant.

My control variables are similar to Coles et al. (2014). SIZE is the natural logarithm of sales, RET is the firm's stock return, $R O A$ is the earnings before extraordinary item divided by total assets, CEO_TENURE is the CEO tenure, CEO_OWNERSHIP is the proportion of outstanding shares held by the CEO, CEO_CHAIR is an indicator variable that equals one if the CEO is the chairman of the board of directors, and zero otherwise, B_INDEPENDENCE is the proportion of outsiders on the board of directors, $B \_O W N E R S H I P$ is the total shares held by directors on a board, divided by total outstanding shares, $B \_S I Z E$ is the number of directors on board, $B_{-} F E M A L E$ is an indicator that equals one if at least one of the directors on board is female, and zero otherwise, and G_INDEX is the governance index described by Gompers et al. (2003), which states that $G 1$ equals one if $G<=6$, and zero otherwise; $G 2$ equals one if $7<=G<=9$, and zero otherwise; $G 3$ equals one if $10<=G<=12$, and zero otherwise; $G 4$ equals one if $G>=13$, and zero otherwise. I also control year fixed effect $(Y E A R)$

Consistent with prior literature, I expect that CEO compensation positively associates with firm size (SIZE), as CEOs of larger firms add more value (Smith and Watts, 1992), and better firm performance, as measured by RET and ROA (Murphy, 1985; Smith and Watts, 1992). Core et al. (1999) show that CEO compensation positively 
relates to CEO_CHAIR, B_SIZE, and negatively relates to CEO_OWNERSHIP, as weak governance tends to increase CEO compensation. I do not predict the sign for B_OWNERSHIP and B_INDEPENDENCE because Core et al. (1999) find an insignificant association between CEO compensation and B_OWNERSHIP, and a negative association between CEO compensation and the proportion of insiders on the board of directors, which is contrary to their prediction. Adams and Ferreira (2009) suggest that female directors impact board decisions as well. I expect that CEO compensation varies with the $B_{-} F E M A L E$, but $\mathrm{I}$ do not predict the sign for the association. Hill and Phan (1991) suggest that the CEO's control over the board of directors and internal information system increase as CEO tenure increases. They find that as CEO tenure grows, CEO pay is more related to firm size and firm risk, but less related to firm performance, which indicates CEOs with longer tenure are more capable to influence their compensation packages. Drawing from their findings, I predict a positive relationship between CEO compensation and CEO tenure.

I rely on the model of Cazier (2011) to test Hypothesis H2a. Cazier (2011) finds no evidence that R\&D spending is related to the CEO horizon problem, and concludes that CEOs do not cut R\&D spending in their final years prior to retirement. However, he fails to take into account the role of the compensation committee in mitigating CEO opportunistic R\&D cutting. $H 2 a$ predicts that $\mathrm{R} \& \mathrm{D}$ spending may negatively associate with the CEO horizon problem if the compensation committee is dominated by co-opted directors, who are less effective monitors. I test $H 2 a$ by estimating model (3) as follows:

$$
\begin{aligned}
R D_{i, t}= & \alpha+\beta_{1} \text { HORIZON }_{i, t}+\beta_{2} \text { COOPTED_CC }_{i, t}+\beta_{3} \text { HORIZON }_{i, t} \\
& \times \text { COOPTED_CC } C_{i, t}+\beta_{4} \text { TOBINS_ } Q_{i, t}+\beta_{5} L A G_{-} R E T_{i, t}+\beta_{6} F C F_{i, t}+
\end{aligned}
$$




$$
\begin{aligned}
& \beta_{7} R O A_{i, t}+\beta_{8} S I Z E_{i, t}+\beta_{9} F I R M_{-} A G E_{i, t}+\beta_{10} E Q U I T Y \_I N C E N T I V E S_{i, t} \\
& +\beta_{11} I N D U S T R Y \_R D_{i, t}+Y E A R+\varepsilon_{i, t}
\end{aligned}
$$

Where $R D$ is the $\mathrm{R} \& \mathrm{D}$ expense scaled by total assets, COOPTED_CC is an indicator variable that equals one if the majority of compensation committee directors are co-opted by the incumbent CEO, and zero otherwise, and HORIZON is an indicator variable that equals to one if the CEO is in the final two years before retirement, and zero otherwise. The interaction term between $H O R I Z O N \times C O O P T E D \_C C$ is interpreted as the indicator variable that equals one if the CEO is approaching retirement and the compensation committee is dominated by co-opted directors. According to $H 2 a$, the coefficient $\beta_{3}$ should be significantly negative, which indicates that R\&D reduction is expected only when compensation committees fail to mitigate CEO opportunistic behaviors.

I also control for other variables that may affect $R \& D$ expenditures and relate to the CEO horizon problem and compensation committee co-option, which are similar to Cazier (2011). TOBINS_Q is calculated as the market value of equity plus the book value of debt, all scaled by total assets, $L A G \_R E T$ is the firm's stock return from the previous year, $F C F$ is the operating cash flows plus $\mathrm{R} \& \mathrm{D}$ expense minus capital expenditures, all scaled by sales, $R O A$ is operating net income before $\mathrm{R} \& \mathrm{D}$ expense scaled by assets, SIZE is the natural logarithm of total assets at the beginning of fiscal year $t, F I R M_{-} A G E$ is the number of years between year $t$ and the first year the company was listed on Compustat. EQUITY_INCENTIVES is the CEO's dollar wealth increase from a one percent change in 
stock price, as measured in Core and Guay's study $(2002)^{5}$. INDUSTRY_RD is the average $R \& D$ expenditure of other firms in the same two-digit SIC industry.

I predict the coefficient on TOBINS_Q $Q$ and $L A G \_R E T$ to be positive, since firms with more growth opportunities may invest more in R\&D. Consistent with Himmelberg and Petersen (1994), I predict that R\&D expenditures positively associate with internal finance, which is measured by the firm's free cash flow $(F C F)$. I predict that R\&D expenditures negatively relate to the accounting flexibility, as measured by $R O A$, since Wang and D'Souza (2006) suggest that when accounting flexibility is low, managers are more likely to engage in real earnings management. I expect that R\&D spending varies with firm size. Cohen and Klepper (1996) suggest that larger firms can apply R\&D results to greater output and therefore reduce the average cost of R\&D. Based on the findings of Huergo and Jaumandreu (2004), I predict that firm age (FIRM_AGE) negatively associates with R\&D expenditures, since older firms are less likely to introduce innovations. CEOs with more equity holdings are more long-term oriented and willing to spend in $R \& D$, although $R \& D$ expenditures reduce current earnings (Barker and Mueller, 2002). Therefore, I predict the coefficient on EQUITY_INCENTIVES to be positive. Consistent with prior studies (Dechow and Sloan, 1991; Cheng, 2004), I also control for the industry average $R \& D$ expenditures. I exclude each firm-year from the calculation of the industry average $\mathrm{R} \& \mathrm{D}$ to prevent a mechanical relation between $R D$ and INDUSTRY_RD.

\footnotetext{
${ }^{5}$ I calculate EQUITY_INCENTIVES as $1 \% \times$ the firm's share price $\times(\#$ of shares $+\#$ of options $\times$ option delta). I follow Core and Guay (2002) methodology to calculate option delta separately for newly granted options, unexercisable options, and exercisable options before the year of 2006. After the passage of SFAS 123R, Execucomp stops providing the inputs necessary to calculate Black-Scholes value of option delta. I follow Execucomp assumptions to construct self-calculated inputs.
} 
To test hypothesis $H 2 b$, I run the following model (4) cross-sectionally:

$$
\begin{aligned}
& D A_{i, t}=\alpha+\beta_{1} H_{O O R I Z O N} N_{i, t}+\beta_{2} \text { COOPTED_CC } C_{i, t}+\beta_{3} H_{O R I Z O N} N_{i, t} \\
& \times C O \_O P T E D \_C C_{i, t}+\beta_{4} E Q U I T Y \_I N C E N T I V E S_{i, t}+\beta_{5} S I Z E_{i, t}+ \\
& \beta_{6} S T D \_C A S H F L O W_{i, t}+\beta_{7} S T D \_R E V_{i, t}+\beta_{8} S T D \_S A L E S G R O W T H_{i, t}+ \\
& \beta_{9} \text { OLDFIRM }_{i, t}+\beta_{10} \text { LEVERAGE }_{i, t}+\beta_{11} \text { MARKETTOBOOK }_{i, t}+ \\
& G_{-} I N D E X+E X C H A N G E+I N D U S T R Y+Y E A R+\varepsilon_{i, t}
\end{aligned}
$$

Hypothesis $H 2 b$ predicts the coefficient $\beta_{3}$ on the interaction term between HORIZON $\times C O O P T E D \_C C$ to be significantly positive, if CEOs have incentive to engage in accruals management to boost their earnings-based compensation, and if compensation committees dominated by co-opted director fail to mitigate their incentives. $D A$ is the discretionary accruals derived from the equation (1c).

My control variables are similar to Bergstresser and Philippon (2006). I control for CEO equity incentive, as CEOs have more incentive to manage earnings when their wealth is more sensitive to the firms' share price (Bergstresser and Philippon, 2006). I follow Bergstresser and Philippon (2006) to measure CEO equity incentives. EQUITY_INCENTIVES is the dollar change in a CEO's wealth from a $1 \%$ change in stock price, as measured in Core and Guay (2002), then normalized by the sum of the dollar change, salary, and bonus. SIZE is the natural logarithm of total assets at the beginning of fiscal year $t$. STD_CASHFLOW is the standard deviation of cash flows from operations deflated by total assets over the current and previous four years. STD_REV is the standard deviation of sales deflated by total assets over the current and previous four years. STD_SALESGROWTH is the standard deviation of sales growth over the current and previous four years. OLDFIRM equals one if a firm has been listed on Compustat for 
more than 20 years, and zero otherwise. LEVERAGE is total liabilities deflated by total assets. MARKETTOBOOK represents deciles of market value of assets divided by the book value of assets ranked within each year. G_INDEX represents the governance indicator variables described in Gompers et al. (2003). Gl is a dummy variable equal to one if the G-score is less than or equal to 6 , and zero otherwise. $G 2$ is a dummy variable equal to one if the G-score is between 7 (inclusive) and 9 (inclusive), and zero otherwise. G3 is a dummy variable equal to one if the G-score is between 10 (inclusive) and 12 (inclusive), and zero otherwise. G4 is a dummy variable equal to one if the G-score is greater than or equal to 13, and zero otherwise. EXCHANGE is an indicator for the stock exchange where the company is traded. INDUSTRY is the Fama and French (1997) industry classification indicator. YEAR represents year indicators.

I expect firm size (SIZE) to negatively associate with discretionary accruals, since larger firms are under more scrutiny by analysts and the press (Duellman et al., 2013). I expect that discretionary accruals vary with firm age (OLDFIRM), the standard deviation of cash flows from operations (STD_CASHFLOW), the standard deviation of revenues (STD_REV), the standard deviation of sales growth (STD_SALESGROWTH), and governance (G_INDEX), consistent with prior literature (Duellman et al., 2013; Jiang et al., 2010).

To examine whether compensation committee co-option affects the committee's effectiveness in adjusting CEO compensation to mitigate the CEO horizon problem, I estimate the regressions (5) and (6) using control variables consistent with Huson et al. (2012). 


$$
\begin{aligned}
& \Delta \operatorname{lnCEO\_ COMP} P_{i, t}=\alpha+\beta_{1} \Delta R O A_{i, t}+\beta_{2} A D J \_R E T_{i, t}+\beta_{3} \Delta R D_{i, t}+ \\
& \beta_{4} H_{O R I Z O N}+\beta_{5} C O O P T E D \_C C_{i, t}+\beta_{6} H_{O R I Z O N} \times \\
& \triangle R O A_{i, t}+\beta_{7} H_{O R I Z O N} \times \text { i,t } \times \text { AD_RET } T_{i, t}+\beta_{8} H_{O R I Z O N} \times N_{i, t} \times \\
& \Delta R D_{i, t}+\beta_{9} H_{O R I Z O N} \times N_{i, t} \times C O O P T E D \_C C_{i, t}+ \\
& \beta_{10} C O O P T E D \_C C_{i, t} \times \Delta R D_{i, t}+\beta \\
& { }_{11} H_{\text {HORIZON }} \times \text { i,t } \times \text { COPTED_CC } C_{i, t} \times \Delta R D_{i, t}+Y E A R+\varepsilon_{i, t}
\end{aligned}
$$

Where $\triangle \ln C E O \_C O M P$ is the change in natural logarithm of CEO compensation ${ }^{6}$. I use three measures of CEO compensation: $\triangle \ln C_{-} P A Y$ is the change in the natural logarithm of CEO salary and bonus. $\triangle \ln T_{-} P A Y$ is the change in the natural logarithm of CEO total compensation, which includes salary, bonus, other annual compensation, restricted stock grants, long-term incentive payouts, all other compensation, and value of option grants (EXECUCOMP data item TDC1). $\triangle \ln L_{-} P A Y$ is the change in natural logarithm of longterm CEO compensation, which is defined as the sum of restricted stock grants, value of option grants, and long-term incentive payouts. $\triangle R O A$ is the change in earnings before extraordinary items, scaled by lagged total assets. $A D J \_R E T$ is the firm's annual sizeadjusted stock return, which is calculated by subtracting the firm's return by the market return for the corresponding market capitalization decile. $\triangle R D$ is the change in $\mathrm{R} \& \mathrm{D}$ expenditures, scaled by lagged total assets. HORIZON is an indicator variable equal to one if CEOs are in the final two years before retirement, and zero otherwise. COOPTED_CC is an indicator variable equal to one if the majority of compensation

\footnotetext{
${ }^{6}$ I only calculate the change in compensation for the same CEO.
} 
committee directors are co-opted by the incumbent CEO, and zero otherwise. YEAR represents year indicators.

$\triangle R O A$ and $\triangle R D$ are both included to examine the different treatment of $\triangle R D$ compared to other earnings components. If $\Delta R D$ is treated the same way as other earnings components when there is no horizon problem, then the coefficient $\beta_{3}$ on $\Delta R D$ should be insignificant, while a significant positive coefficient should indicate shielding of $\Delta R D$ from CEO compensation. The variable of interest is the interaction term between HORIZON, COOPTED_CC, and $\triangle R D$. H3a predicts that compensation committees dominated by co-opted directors are less effective in mitigating opportunistic R\&D reduction when CEOs approach retirement. Effective compensation committees can reduce the negative relationship between $\mathrm{R} \& \mathrm{D}$ expenditure and CEO compensation by shielding $\mathrm{R} \& \mathrm{D}$ from $\mathrm{CEO}$ compensation or tying CEO compensation to $\mathrm{R} \& \mathrm{D}$. Nevertheless, compensation committees dominated by co-opted directors are less effective in adjusting the negative relationship between R\&D and CEO compensation. Therefore, when CEOs reduce R\&D spending, they are more likely to increase their compensation prior to retirement. I expect the coefficient $\beta_{11}$ to be negative, if $H 3 a$ is correct.

Consistent with prior studies (Murphy, 1985; Smith and Watts, 1992), I expect CEO compensation to be positively associated with accounting performance $(\triangle R O A)$ and stock performance $\left(A D J \_R E T\right)$. I include the interaction terms $H O R I Z O N \times \triangle R O A$ and HORIZON $\times A D J \_R E T$ because Lewellen et al. (1987) suggest the proportion of accounting-related compensation and stock-related compensation is adjusted to address CEO horizon problem. I expect the coefficient $\beta_{6}$ on $H O R I Z O N \times \triangle R O A$ to be negative 
and $\beta_{7}$ on $H O R I Z O N \times A D J \_R E T$ to be positive, which indicates CEO compensation shifts from accounting-based compensation to stock-based compensation to reduce the agency costs related to the CEO horizon problem. When $\triangle \ln C_{-} P A Y$ is the dependent variable, I also control for CEO equity incentives (EQUITY_INCENTIVES), as CEO equity holdings may be one of the factors that compensation committees consider to determine CEO cash compensation (Huson et al., 2012).

Hypothesis $H 3 b$ predicts a more positive association between change in CEO compensation and a positive change in discretionary accruals when a compensation committee is dominated by co-opted directors. To test $H 3 b$, I estimate regression (6) as follows:

$$
\begin{aligned}
& \Delta \ln C E O \_C O M P_{i, t}=\alpha+\beta_{1} \Delta R O A_{i, t}+\beta_{2} A D J \_R E T_{i, t}+\beta_{3} P O S \_\Delta D A_{i, t}+ \\
& \beta_{4} N E G_{-} \Delta D A_{i, t}+\beta_{5} H O R I Z O N_{i, t}+\beta_{6} C O O P T E D \_C C_{i, t}+ \\
& \beta_{7} H_{O R I Z O N} \times N_{i, t} \times \triangle R O A_{i, t}+\beta_{8} H_{O R I Z O N} N_{i, t} \times A D J \_R E T_{i, t}+ \\
& \beta_{9} H O R I Z O N_{i, t} \times P O S \_\Delta D A_{i, t}+\beta_{10} H O R I Z O N_{i, t} \times \\
& N E G_{-} \Delta D A_{i, t}+\beta_{11} \text { HORIZON }_{i, t} \times C O O P T E D \_C C_{i, t}+ \\
& \beta_{12} C O O P T E D \_C C_{i, t} \times P O S \_\Delta D A_{i, t}+ \\
& \beta_{13} C O O P T E D \_C C_{i, t} \times N E G \_\Delta D A_{i, t}+\beta \\
& { }_{14} H_{O O R I Z O N}{ }_{i, t} \times C O O P T E D \_C C_{i, t} \times P O S \_\Delta D A_{i, t}+ \\
& \beta_{15} H O R I Z O N_{i, t} \times C O O P T E D \_C C_{i, t} \times N E G_{-} \Delta D A_{i, t}+ \\
& Y E A R+\varepsilon_{i, t}
\end{aligned}
$$

Where $P O S \_\triangle D A$ is the positive changes in discretionary accruals, and $N E G_{-} \triangle D A$ is the negative changes in discretionary accruals. My variable of interest is the interaction term $H O R I Z O N \times C O O P T E D \_C C \times P O S \_\triangle D A$. I expect the coefficient to be positive, if $H 3 b$ is 
correct. My hypothesis only predicts that CEOs have incentives to engage in incomeincreasing accruals management, and compensation committees dominated by co-opted directors are less effective to mitigate the income-increasing accruals management. Consequently, I focus on the positive change of discretionary accruals. I test the interaction term $H O R I Z O N \times C O O P T E D \_C C \times N E G \_\triangle D A$ for completeness. Nevertheless, I make no prediction about the sign of its coefficient.

\section{RESULTS}

\subsection{Sample}

Table 1 Panel A presents the sample selection procedure. I collect director data from RiskMetrics for the period from 1998 to 2011. RiskMetrics provides director information, including committee membership, shareholding, age, independence, additional directorships, and tenure, as well as the year directorship starts for directors in S\&P 500, S\&P MidCap, and S\&P SmallCap firms. I lose 2,445 firm-year observations as they lack CEO compensation data from Execucomp. I further lose 479 firm-year observations which miss the date when the CEO was hired. I exclude 2,788 financial institutions (SIC codes 6000-6999) similar to prior studies. I exclude another 595 observations that are missing Compustat inputs to calculate sales, return, and ROA, and 352 observations lacking number of shares held by the CEO. Finally, I trim the top and bottom one percent of all continuous variables to mitigate the effect of outliers. My final sample consists of 13,606 firm-year observations ${ }^{7}$.

\footnotetext{
${ }^{7}$ When estimating model (3)-(6), I further remove the firm-year observations with CEO tenure less than 3 years, to avoid the influence of the previous CEO.
} 
[See Table 1 Panel A, p.72]

In Table 1 Panel B, I present the number of firm-year observations in each of Fama-French (1997) 48 industries as well as average value of two measures of compensation committee co-option in each industry. The percentage of co-opted directors sitting on a compensation committee is 0.278 for the industry of candy and soda, which is the lowest, while the industry of nonmetallic mines has the highest percentage of coopted directors on a compensation committee, which is as high as 0.649 .

[See Table 1 Panel B, p.72]

In Table 1 Panel C, I provide the number of firm-year observations in each fiscal year for the period of 1998 to 2011 as well as average value of two measures of compensation committee co-option for each fiscal year. The mean value of the percentage of co-opted directors on a compensation committee varies by years. The lowest average value of CC_COOPTION is 0.394 in the year of 2001, while the highest average value of CC_COOPTION is 0.453 in the year of 2010 .

[See Table 1 Panel C, p.72]

Table 1 Panel D displays the descriptive statistics for the variables used in model (2), and are consistent with the descriptive statistics reported by Coles et al. (2014). Pearson correlations are reported in Table 1 Panel E.

[See Table 1 Panel D, p.72]

[See Table 1 Panel E, p.72]

\subsection{Regression Results}

Table 2 presents the multivariate analysis of the effect of compensation committees dominated by co-opted directors on total CEO compensation. The reported p- 
values presented in parentheses and are one-tailed for coefficients that have the predicted sign, and two-tailed for those without a predicted sign or those that do not have the predicted sign. The standard errors are heteroskedasticity robust, and clustered by firm and year. The coefficient on COOPTED_CC is significantly positive $(\mathrm{p}<0.01)$, which indicates that $\mathrm{CEO}$ receive higher compensation in companies with compensation committees dominated by co-opted directors, holding all else constant. My findings support Hypothesis $H 1$.

[See Table 2, p.78]

Among the control variables, firm size, firm performance, and CEO duality are positively associated with CEO compensation, while director ownership is negatively associated with CEO compensation, as expected. I do not find CEO tenure or board size to be associated with CEO compensation.

[See Table 3, p.79]

Panel A and Panel B of Table 3 report the descriptive statistics and Pearson correlations for the variables used in model (3), respectively. Table 4 reports the regression analysis of the effect of compensation committees dominated by co-opted directors on the association between $\mathrm{R} \& \mathrm{D}$ spending and the $\mathrm{CEO}$ horizon problem. The coefficient on HORIZON is not significantly different from zero, which is consistent with prior studies which state that $\mathrm{R} \& \mathrm{D}$ spending is not related to the CEO horizon problem (Cazier, 2011). However, the coefficient on the interaction term HORIZON $\times C O O P T E D \_C C$ is significantly negative $(\mathrm{p}=0.03)$. Taken together, the results indicate that $R \& D$ reduction only exists in firms that have a CEO horizon problem 
and a compensation committee dominated by co-opted directors, which is consistent with Hypothesis $H 2 a$.

[See Table 4, p.81]

Panel A and Panel B of Table 5 report the descriptive statistics and Pearson correlations for the variables used in model (4), respectively. The regression analysis of the effect of compensation committees dominated by co-opted directors on the association between discretionary accruals management and the CEO horizon problem is presented in Table 6. The coefficient on the interaction term HORIZON $\times$ COOPTED_CC is positive and significant $(\mathrm{P}=0.05)$. The coefficient on HORIZON is not significantly different from zero. This suggests that CEOs engage in accruals management only when the horizon problem exists and when the compensation committee is dominated by coopted directors, which is consistent with Hypothesis $H 2 b$.

[See Table 5, p.82]

[See Table 6, p.84]

Panel A and Panel B of Table 7 report the descriptive statistics and Pearson correlations for the variables used in model (5), respectively. The estimates in Table 8 show the multivariate regression results of whether compensation committees dominated by co-opted directors are less effective in adjusting CEO compensation to prevent opportunistic R\&D reduction when firms face a CEO horizon problem. The first column shows the regression results when the change in CEO cash compensation is a dependent variable, while the results for the change in total CEO compensation and the change in long-term CEO compensation are presented in column (2) and column (3), respectively. In column (2), the coefficient on $H O R I Z O N \times \Delta R D$ is significantly positive $(\mathrm{p}=0.09)$, 
suggesting that $\mathrm{R} \& \mathrm{D}$ expenditures are generally shielded from total $\mathrm{CEO}$ compensation when firms have a CEO horizon problem. The coefficient on $H O R I Z O N \times C O O P T E D \_C C \times \triangle R D$ is negative and significant $(\mathrm{p}=0.05)$. The negative association suggests that retiring CEOs in firms with a compensation committee dominated by co-opted directors are more likely to increase their compensation by reducing $R \& D$ expenditures.

[See Table 7, p.85]

[See Table 8, p.87]

In Table 9, I present the OLS regression results of whether compensation committees dominated by co-opted directors are less effective in adjusting CEO compensation in the final years prior to $\mathrm{CEO}$ retirement to prevent income-increasing accruals management. The coefficients on $H O R I Z O N \times P O S \_\triangle D A$ are not significantly different from zero in all three columns. The coefficient on $H O R I Z O N \times C O O P T E D \_C C \times P O S \_\triangle D A$ is positive and significant $(\mathrm{p}=0.08)$ in column (1), indicating that change in CEO cash compensation is more positively associated with income-increasing discretionary accruals when CEOs present a horizon problem and compensation committees are dominated by co-opted directors.

[See Table 9, p.88]

Overall, my findings provide empirical support for Hypothesis $H 3 a$ and Hypothesis $H 3$.

\subsection{Sensitivity Tests}

As CEOs stay longer with a firm, more directors are appointed during the CEO's tenure. Therefore, co-option captures the effect of CEO tenure. Coles et al. (2014) 
address this issue by both controlling for CEO tenure and developing a measure RES_CC_COOPTION, which is the residual from regression of CC_COOPTION on CEO tenure. I follow their measure, and I control for CEO tenure and other board governance. Another issue with the co-option measure is that it may capture the inexperience of new directors. The newly appointed directors may be less effective because they are new to their job, rather than because they are captured by the CEO. Therefore, following Coles et al. (2014) I develop TW_CC_COOPTION, the director tenure weighted co-option, which is the sum of tenure of co-opted compensation committee directors divided by the sum of tenure of all compensation committee directors. I also calculate RES_TW_CC_COOPTION, which is the residual from the regression of $T W \_C C \_C O O P T I O N$ on $\mathrm{CEO}$ tenure.

[See Table 10 Panel A, p.89]

Table 10 Panel A reports the regression results of CEO compensation on the alternative measures of compensation committee co-option. The coefficient on CC_COOPTION is positive and significant $(\mathrm{p}<0.01)$ in column $(1)$, suggesting that $\mathrm{CEO}$ compensation positively associates with the percentage of co-opted directors on a compensation committee. The coefficients on TW_CC_COOPTION, RES_CC_COOPTION, RES_TW_CC_COOPTION are all positive and significant $(\mathrm{p}<0.01)$. This significance suggests that compensation committee co-option captures more than CEO tenure and director inexperience. I also report the regression analysis of the effect of compensation committees dominated by co-opted directors on adjusting a CEO's opportunistic R\&D reduction and accruals management, after controlling for other corporate governance in Table 10 Panel B and Table 10 Panel C, respectively. My 
findings still hold after controlling for CEO tenure, CEO duality, board independence, and board size.

[See Table 10 Panel B, p.89]

[See Table 10 Panel C, p.89]

Direct CEO involvement in the firm's director nomination process has been reduced since 2004. NYSE Corporate Governance Section 303A, NASDAQ Rule 4350 (c), and AMEX Enhanced Corporate Governance Rules, section 805 requires that nomination committees of listed firms must solely consist of independent directors. Therefore, I examine the subsample consisting of firm-year observations during the period 2004-2011. Panel D of Table 10 shows that CEO compensation is positively associated with compensation committees dominated by co-opted directors.

[See Table 10 Panel D, p.89]

Table 10 Panel $E$ shows that the coefficient on interaction term HORIZON $\times C O O P T E D \_C C$ is negative but insignificant. Table 10 Panel F reports that the coefficient on the interaction term $H O R I Z O N \times C O O P T E D_{-} C C$ is significantly positive, suggesting discretionary accruals is higher in firms with retiring CEOs and compensation committees dominated by co-opted directors.

[See Table 10 Panel E, p.89]

[See Table 10 Panel F, p.89]

Table 10 Panel $G$ shows that the coefficient on the interaction term $H O R I Z O N \times C O O P T E D \_C C \times \triangle R D$ is insignificant in all three columns. Table 10 Panel $\mathrm{H}$ reports that the coefficient on the interaction term $H O R I Z O N \times C O O P T E D \_C C \times P O S \_\triangle D A$ is significantly positive in column (1), 
suggesting that CEOs are more likely to increase their cash compensation using incomeincreasing accruals management when compensation committees are dominated by coopted directors. Overall, I do not find evidence that compensation committees dominated by co-opted directors are less effective in alleviating $R \& D$ reduction when CEOs present their firms with a horizon problem in the subsample. However, I still find evidence that compensation committees dominated by co-opted directors are less effective in reducing CEO compensation and mitigating accruals management when CEOs approach retirement after the year of 2004 .

[See Table 10 Panel G, p.89]

[See Table 10 Panel H, p.89]

\section{BOARD AND COMPENSATION COMMITTEE CHARACTERISTICS 5.1 Literature Review and Hypothesis Development}

\section{CEO Power}

CEOs who are also chairmen of the board of directors can exert more influence over the decision-making process (Adams et al., 2005). Jensen (1993) advocates the separation of the CEO and chairman positions, arguing that chairmen are responsible for overseeing CEOs, but if CEOs also hold the position of chairmen, they may act in their own interests when they perform critical functions such as evaluating and compensating themselves. Dechow et al. (1996) provide empirical evidence, and find that firms subject to enforcement actions by the SEC for earnings management are more likely to have CEOs who also serve as chairmen of the board of directors. 
Director monitoring is a critical mechanism to alleviate agency costs; however, the effectiveness of the monitoring is reduced if the chairman of the board is assumed by the CEO, or if most of the directors on the board are co-opted by the incumbent CEO. Hence, I predict:

H4a: CEO compensation is positively associated with CEO power.

H4b: CEO horizon problem is positively associated with CEO power.

\section{Director Independence}

It's been widely documented that directors who are more independent monitor managers more effectively. Weisbach (1988) shows that boards dominated by outside directors are more likely to remove CEOs when the companies suffer from poor performance. A number of studies show that board independence improves the quality of the financial reporting process. Dechow et al. (1996) find that board independence is inversely associated with the likelihood of being charged by SEC for earnings manipulations. Similarly, Beasley (1996) finds that board independence negatively associates with financial statement fraud. Uzun et al. (2004) compare the governance in firms that have committed fraud and those that have not. They note that the percentage of independent directors is higher in firms that have not engaged in fraud than the firms that have. Klein (2002a) documents a negative association between board independence and abnormal accruals. Board independence also improves firm disclosures (Ajinkya et al., 2005; Karamanou and Vafeas, 2005). Finally, Byard et al. (2006) show that the quality of analysts' earnings forecast an increase if the board is more independent. 
If independent directors are more aligned with shareholder benefits, I expect that board and compensation committee independence reduce CEO pay and the CEO horizon problem. Therefore, I hypothesize that:

H5a: CEO compensation is negatively associated with board and compensation committee independence.

H5b: CEO horizon problem is negatively associated with board and compensation committee independence.

\section{Board and Compensation Committee Size}

A number of scholars have expressed their concern about large board sizes (Lipton and Lorsch, 1992; Jensen, 1993; Yermack, 1996). For example, Lipton and Lorsch (1992) suggest that board sizes should not be larger than ten members, since it is difficult for every director to express his or her opinion freely in the limited time when they meet. Moreover, they point out that it's hard for a large board to become a cohesive body due to poor communication and lack of a common purpose. Jensen (1993) argues that boards that consist of more than seven or eight members are more subjective to CEO control. Those two studies are consistent with organizational behavior research studies, such as Steiner (1972) and Hackman (1990), which argue that as work groups become larger, productivity decreases. Yermack (1996) provides empirical evidence that board size negatively associates with a firm's value. He also shows that firms with large boards are less likely to have favorable profitability and operating efficiency financial ratios, to provide $\mathrm{CEO}$ compensation sensitive to firm performance, and to remove CEOs.

In contrast, larger boards have a wider knowledge base and it's easier for larger boards to distribute the workload. For example, Klein (2002b) and Anderson et al. (2004) 
suggest that large boards are more effective in monitoring the financial accounting process. Klein (2002b) suggests that as a board size increases, the board is more likely to assign an independent audit committee. Consistent with her prediction, she finds that as a board size increases, an audit committee's independence increases. Anderson et al. (2004) find that larger boards are associated with lower cost of debt, while Karamanou and Vafeas (2005) find that larger boards are more likely to update management earnings forecasts. Laksmana (2008) finds that board size increases the executive compensation disclosure transparency.

Whether a firm can benefit from a large board of directors may depend on the complexity of the firm (Coles et al., 2008). Coles et al. (2008) argue that complex firms, those high in industry diversification, size, and leverage, require more advising from their board of directors, and as a result can benefit from a large board. They find that for simple firms, firm value decreases as board size increases; however, for complex firms, firm value increases as board size increases. Drawing from the findings of previous studies, I predict that the size of the board and compensation committee affects CEO compensation and CEO horizon problem. Nevertheless, I make no prediction about the sign. I hypothesize that:

H6a: CEO compensation is associated with board and compensation committee size.

H6b: CEO horizon problem is associated with board and compensation committee size.

\section{Busy Directors}


The number of directorship may be a sign of director reputation, since an external labor market disciplines directors by rewarding or reducing directorships based on their performance (Kaplan and Reishus, 1990; Gilson, 1990). Kaplan and Reishus (1990) find that CEOs whose dividends are reduced are less likely to sit on other boards. Gilson (1990) finds that the directorships reduce after directors resign from financially distressed firms. Consistently, Ferris et al. (2003) find that previous firm performance has a positive effect on directors' ability to attract directorships. Two studies examine the association between the likelihood of being a target of takeover and number of directorships (Shivdasani, 1993) and future directorships (Harford, 2003). Shivdasani (1993) documents that firms with outside directors holding fewer additional directorships are more likely to be a target of hostile takeover attempts. Harford (2003) documents that directors of a takeover or merger target lose future directorships. Ferris et al. (2003) find no support that busy directors are less effective monitors. They find no evidence that the number of directorships per director or number of directorships held by outside directors relate to firm value or the likelihood of securities fraud litigation. Moreover, they find positive abnormal returns in an event study that announced the addition of a director who held multiple directorships to the board for the first time, suggesting shareholders value the reputation of directors. They also find that directors holding multiple directorships sit on more committees and attend more committee meetings, which contrast the idea that directors holding multiple directorships are overcommitted and shirk their responsibilities.

However, Lipton and Lorsch (1992) are concerned that directors are busy with more than one board, and cannot emphasize one particular board. Beasley (1996) documents a positive relationship between the number of additional directorships held by 
outside directors and the likelihood of financial statement fraud. Fich and Shivdasani (2006) define busy directors as those who hold three or more directorships. They show that firms with boards dominated by outside busy directors have lower market-to-book ratios, lower operating performance, and are less likely to remove CEOs for poor performance. They also find positive abnormal returns after busy outside directors announce their departure. Furthermore, they find negative abnormal returns when a director becomes a busy director as a result of obtaining one additional directorship, and even more negative when the board becomes dominated by busy directors. Core et al. (1999) measure busy directors as those who serve on three or more corporate boards. They argue that by focusing on directors who hold more than two other directorships rather than on those with average directorships, they can capture the degree of a director's over-commitment. They find that as the percentage of busy outside directors increases, CEO compensation increases. Shivdasani and Yermack (1999) find that if CEOs can exert more influence on the appointment of new directors positively, the appointee is more likely to be a busy director and hold more board seats, which indicates that CEOs prefer less effective monitors. If busy directors cannot devote adequate time and attention to one particular board, the percentage of busy directors on the board or compensation committee may increase CEO compensation and the CEO horizon problem. Therefore, I predict:

H7a: CEO compensation is positively associated with the percentage of busy directors on boards of directors and compensation committees. 


\section{H7b: The CEO horizon problem is positively associated with the}

percentage of busy directors on boards of directors and compensation committees.

\section{Director Tenure}

As director tenure increases, directors gain more experience. More experienced directors can provide higher quality governance. For example, Buchanan (1994) shows that managers' years of organizational service can enhance their commitment to exert high levels of effort to achieve the goal of the firm. Beasley (1996) finds that as outside director tenure increases, the likelihood of financial statement fraud decreases.

However, Katz (1982) finds that long tenure can be detrimental to the communication within and outside of organizations, due to the increasing stability in membership by studying R\&D project groups with different group longevity. Vafeas (2003a) argues that directors with long tenure are more likely to be friendly to managers. He finds that senior directors who have held their board seats for twenty years or more in the compensation committee pay CEOs more generously, which supports the theory that long tenure compromises director monitoring efforts. The National Association of Corporate Directors (1996) advocates a limit of 10 to 15 years of board service so that new directors can bring new ideas and the board can better accommodate to the changing business conditions. If directors are more likely to be entrenched if they hold their directorships for a long time, I expect that the average tenure of directors on a board or a compensation committee increases CEO compensation and the CEO horizon problem. I hypothesize that: 
H8a: CEO compensation is positively associated with the tenure of directors on boards of directors and compensation committees.

H8b: CEO horizon problem is positively associated with the tenure of directors on boards of directors and compensation committees.

\section{Director Ownership}

Directors who have high equity ownership have more incentives to monitor CEOs (Shivdasani and Yermack, 1999). Among others, Shivdasani (1993), Vafeas (2003a), Klein (2002a), and Beasley (1996) provide evidence that directors with high ownership are more aligned with shareholders. Shivdasani (1993) documents a negative association between equity ownership by outside directors and the possibility of firms being a target of hostile takeover attempts. Vafeas (2003a) shows that director ownership is rather low, even for senior directors whose tenure is longer than twenty years. He finds a negative relationship between director ownership and total CEO pay. Klein (2002a) documents an inverse association between the presence of an outside blockholder on an audit committee and abnormal accruals, indicating that director ownership affects the monitoring over financial reporting quality. Beasley (1996) finds that directors in firms who commit fraud have higher ownership than directors in no-fraud firms. Rosenstein and Wyatt (1997) note that shareholders value the expertise of inside directors when they own more than five percent of the firm's shares when investigating the stock market reaction to the addition of insiders in a board of directors. However, Core et al. (1999) find no empirical evidence that CEO compensation associates with director ownership. If director ownership enhances the alignment between directors and shareholders, I expect that as 
director ownership increases, CEO compensation and the CEO horizon problem decreases, holding all else constant. Hence:

H9a: CEO compensation is negatively associated with the average tenure of directors on boards of directors and compensation committees.

H9b: The CEO horizon problem is negatively associated with the average tenure of directors on boards of directors and compensation committees.

\subsection{Research Design}

Table 11 shows the Pearson correlations between the variables in this study to capture board and compensation committee characteristics. CC_COOPTION is the proportion of directors who are appointed after the CEO assumes office on the compensation committee. $B \_C O O P T I O N$ is the proportion of directors who are appointed after the CEO assumes office on the board of directors. COOPTED_CC is an indicator variable equal to one if the majority of compensation committee directors are co-opted by the incumbent $\mathrm{CEO}$, and zero otherwise. COOPTED_B is an indicator variable equal to one if the majority of directors on a board are co-opted by the incumbent $\mathrm{CEO}$, and zero otherwise. CEO_CHAIR is an indicator variable equal to one if the CEO is the chairman of the board of directors, and zero otherwise. B_INDEPENDENCE is the proportion of outsiders on the board of directors. CC_ INDEPENDENCE is the proportion of outsiders on a compensation committee. IND_NORM is an indicator variable equal to one if the firm has a nominating committee that consists of only outside directors. CC_SIZE is the number of directors on a compensation committee. $B \_S I Z E$ is the number of directors on the board of directors. Fich and Shivdasani (2006) argue that since the number of 
directorships held by directors disperses widely, the average number of directorships is a noisy measure to identify busy directors. Therefore, I define busy directors as those who hold more than three additional directorships. $B_{-} B U S Y$ is the proportion of board directors who sit on more than three other boards of public companies. CC_BUSY is the proportion of compensation committee directors who sit on more than three other boards of public companies. B_LONGSERV is the average tenure of directors on a board. CC_LONGSERV is the average tenure of directors on a compensation committee. CC_OWNERSHIP is the total shares held by directors on a compensation committee divided by total outstanding shares. B_OWNERSHIP is the total shares held by directors on a board divided by total outstanding shares. B_SIZE is the number of directors on board.

[See Table 11, p.101]

Most of those variables are correlated. Therefore, I use a principal component analysis to transform board and compensation committee characteristic variables into a set of common factors. Consistent with Laksmana (2002), I retain all factors with an eigenvalue greater than one. I use an oblique rotation since oblique rotation often produces more useful patterns than do orthogonal rotations. Six factors with an eigenvalue greater than one are retained and those six factors can explain $79.78 \%$ of the variation.

Table 12 presents the factors identified in a principal components analysis. CC_COOPTION, B_COOPTION, COOPTED_CC,COOPTED_B, and CEO_CHAIR have high loadings on the first factor CEO_POWER. B_INDEPENDENCE, CC_INDEPENDENCE and IND_NORM load highly on the second factor 
INDEPENDENCE. Two variables, CC_SIZE and B_SIZE, have high loadings on the third factor DIR_SIZE. B_BUSY and CC_BUSY have high loadings on the fourth factor, BUSY_DIR. Two variables measuring director tenure, B_LONGSERV and CC_LONGSERV, load highly on the fifth factor, DIR_TENURE. CC_OWNERSHIP and B_OWERSHIP have high loadings on the sixth factor, DIR_OWNERSHIP.

[See Table 12, p.103]

\subsection{Results}

Table 13 shows the regression results of CEO compensation on board and compensation committee factors. Consistent with the prediction of $\mathrm{H} 4 \mathrm{a}$ and $\mathrm{H7a}$, CEO_POWER $(\mathrm{p}<0.01)$ and BUSY_DIR $(\mathrm{p}<0.01)$ are positively associated with CEO compensation. In support of $H 9 a, D I R \_O W N E R S H I P$ is negatively associated with CEO compensation $(\mathrm{p}<0.01)$. The coefficient on DIR_INDEPENDENCE, DIR_SIZE, and DIR_TENURE is not significantly different from zero.

[See Table 13, p.104]

The multivariate analysis of the effect of board and compensation committee factors on the association between R\&D spending and the CEO horizon problem is presented in Table 14. The coefficient on the interaction term HORIZON $\times C E O \_P O W E R$ is negative and significant ( $\mathrm{p}=0.03$ ), suggesting that as $\mathrm{CEO}$ power increases, CEOs are more likely to reduce $R \& D$ expenditures when they approach retirement. The coefficient on the interaction term HORIZON $\times$ DIR_TENURE is significantly negative $(\mathrm{p}=0.02)$, which indicates that as the average tenure of directors on boards and compensation committees increases, retiring CEOs are more likely to cut R\&D expenditures. The results provide support for $H 4 b$ and $H 8 b$. Inconsistent with my prediction, the coefficient 
on HORIZON $\times$ DIR_INDEPENDENCE, HORIZON $\times$ DIR_SIZE, HORIZON $\times B U S Y \_D I R$, and HORIZON $\times$ DIR_OWNERSHIP is insignificant.

[See Table 14, p.105]

Table 15 reports the regression analysis of the effect of board and compensation committee factors on the association between accruals management and the CEO horizon problem. The coefficient on the interaction term HORIZON $\times$ DIR_SIZE is negative and significant $(\mathrm{p}=0.02)$, which indicates that the size of the board and compensation committee affect the likelihood of accruals management when CEOs present their firms with a horizon problem. Contrary to expectations, the coefficient on HORIZON $\times D I R \_O W N E R S H I P$ is negative and marginally significant $(\mathrm{p}=0.10)$.

[See Table 15, p.107]

\section{CONCLUSION}

Directors who are co-opted by CEOs are more likely to be sympathetic to CEOs or less willing to challenge CEOs since they feel in debt to CEOs for their directorship. I find that the percentage of co-opted directors on compensation committees is positively associated with $\mathrm{CEO}$ compensation. I also find compensation committees that are dominated by co-opted directors tend to pay higher CEO compensation than committees that are not dominated by co-opted directors.

Extant literature suggests that compensation committees play an important role in mitigating the CEO horizon problem. However, the effectiveness of compensation committees in this role varies. My results show that the percentage of co-opted directors 
on a compensation committee has a negative effect on the association between $R \& D$ spending and the CEO horizon problem. Moreover, retiring CEOs are more likely to reduce $\mathrm{R} \& \mathrm{D}$ spending if the compensation committee is dominated by co-opted directors. I do not find evidence that the percentage of co-opted directors affects the association between discretionary accruals and the CEO horizon problem. However, I find that CEOs are more likely to engage in income-increasing accruals management in the final years prior to their retirement if the compensation committee is dominated by co-opted directors. Taken together, the findings indicate that a horizon problem exists when CEOs approach retirement and when the compensation committee is dominated by co-opted directors.

I further investigate whether compensation committees dominated by co-opted directors are less effective in adjusting CEO compensation to mitigate the CEO horizon problem. Consistent with my prediction, I document that retiring CEOs are more likely to increase their total compensation by reducing R\&D spending if compensation committees are dominated by co-opted directors. I also document that income-increasing accruals are more likely to be rewarded when CEOs approach retirement, and when compensation committees are dominated by co-opted directors.

Finally, I examine whether board and compensation committee characteristics are associated with CEO compensation and the CEO horizon problem using a principal components analysis. I find evidence that CEO compensation is positively associated with CEO power and busy directors, while negatively associated with director ownership. In addition, I find that both CEO power and director tenure increases the likelihood of R\&D curtailment when CEOs approach retirement. I also find that the size of the board 
of directors and the compensation committee affect the likelihood of accruals management when CEOs present their firms with a horizon problem.

This study contributes in three ways. First, it reveals that although CEOs' direct involvement in the appointment process of new directors has been reduced since 2004, co-opted directors act as weak monitors. Second, the study adds empirical evidence to the debate of the CEO horizon problem, finding that retiring CEOs engage in opportunistic R\&D cutting and income-increasing accruals management. Third, the study extends the literature on corporate governance. The findings reveal that compensation committees play an important role in mitigating the $\mathrm{CEO}$ horizon problem by adjusting $\mathrm{CEO}$ compensation. However, the effectiveness of compensation committees in this role is contingent on its quality. 


\section{REFERENCES}

Adams, R. B., and Ferreira, D. (2009). Women in the Boardroom and Their Impact on Governance and Performance. Journal of Financial Economics, 94:291-309.

Adams, R. B., Almeida, H., and Ferreira, D. (2005). Powerful CEOs and Their Impact on Corporate Performance. The Review of Financial Studies, 18 (4):1403-1432.

Adut, D., Cready, W. H. and Lopez, T. J. (2003). Restructuring Charges and CEO Cash Compensation: A Reexamination. The Accounting Review, 78 (1):169-192.

Ajinkya, B., Bhojraj, S., and Sengupta, P. (2005). The Association between Outside Directors, Institutional Investors and the Properties of Management. Journal of Accounting Research, 43 (3):343-376.

Anderson, R. C., and Bizjak, J. M. (2003). An Empirical Examination of the Role of the $\mathrm{CEO}$ and the Compensation Committee in Structuring Executive Pay. Journal of Banking and Finance, 27 (7):1323-1348.

Anderson, R. C., Mansi, S. A., and Reeb, D. M. (2004). Board Characteristics, Accounting Report Integrity, and the Cost of Debt. Journal of Accounting and Economics, 37 (3):315-342.

Antia, M., Pantzalis, C., and Park, J. C. (2010). CEO Decision Horizon and Firm Performance: An Empirical Investigation. Journal of Corporate Finance, 16 (3):288-301.

Balsam, S. (1998). Discretionary Accounting Choices and CEO Compensation. Contemporary Accounting Research, 15 (3):229-252.

Barker III, V. L., and Mueller, G. C. (2002). CEO Characteristics and Firm R\&D Spending. Management Science, 48 (6):782-801.

Beasley, M. S. (1996). An Empirical Analysis of the Relation between the Board of Director Composition and Financial Statement Fraud. The Accounting Review, 71(4):443-465.

Bebchuk, L. A., Fried, J. M., and Walker, D. I. (2002). Managerial Power and Rent Extraction in the Design of Executive Compensation. Harvard Law School John M. Olin Center for Law, Economics and Business Discussion Paper Series. Paper 366.

Bebchuk, L. A., and Fried, J. M. (2005). Pay without Performance: Overview of the Issues. Journal of Applied Corporate Finance, 17 (4):8-23.

Bebchuk, L. A., Grinstein, Y., and Peyer, U. (2010). Lucky CEOs and Lucky Directors. The Journal of Finance, 65 (6):2363-2401. 
Bergstresser, D., and Philippon, T. (2006). CEO Incentives and Earnings Management. Journal of Financial Economics, 80 (3):511-529.

Black, F., and Scholes, M. (1973). The Pricing of Options and Corporate Liabilities. The Journal of Political Economy, 81:637-654.

Buchanan, B. (1974). Building Organizational Commitment: The Socialization of Managers in Work Organizations. Administrative Science Quarterly, 19 (4):533-546.

Butler, S. A., and Newman, H. A. (1989). Agency Control Mechanism Effectiveness and Decision Making in an Executive's Final Year with a Firm. Journal of Institutional and Theoretical Economics, 145:451-464.

Byard, D., Li, Y., and Weintrop, J. (2006). Corporate Governance and the Quality of Financial Analysts' Information. Journal of Accounting and Public Policy, 25(5): 609625.

Cai, J., Garner, J. L., and Walkling, R. A. (2009). Electing Directors. The Journal of Finance, 64 (5):2389-2421.

Capezio, A., Shields, J., and O'Donnell, M. (2011). Too Good to be True: Board Structural Independence as a Moderator of CEO Pay-for-Firm-Performance. Journal of Management Studies, 48 (3):487-513.

Cazier, R. A. (2011). Measuring R\&D Curtailment among Short-Horizon CEOs. Journal of Corporate Finance, 17 (3):584-594.

Cheng, S. (2004). R\&D Expenditures and CEO Compensation. The Accounting Review, 79 (2):305-328.

Chhaochharia, V., and Grinstein, Y. (2009). CEO Compensation and Board Structure. The Journal of Finance, 64 (1):231-261.

Cohen, W. M., and Klepper, S. (1996). A Reprise of Size and R \& D. The Economic Journal, 106 (437):925-951.

Coles, J. L., Daniel, N. D., and Naveen, L. (2008). Boards: Does One Size Fit All? Journal of Financial Economics, 87 (2):329-356.

Coles, J. L., Daniel, N. D., and Naveen, L. (2014). Co-opted Boards. Review of Financial Studies, 27 (6):1751-1796.

Collins, D. W., Gong, G., and Li, H. (2009). Corporate Governance and Backdating of Executive Stock Options. Contemporary Accounting Research, 26 (2):403-445.

Conyon, M. J. (2006). Executive Compensation and Incentives. The Academy of Management Perspectives, 20 (1):25-44. 
Conyon, M. J., and Peck, S. I. (1998). Board Control, Remuneration Committees, and Top Management Compensation. Academy of Management Journal, 41 (2):146-157.

Core, J., and Guay, W. (2002). Estimating the Value of Employee Stock Option Portfolios and Their Sensitivities to Price and Volatility. Journal of Accounting Research, 40 (3):613-630.

Core, J. E., Holthausen, R. W., and Larcker, D. F. (1999). Corporate Governance, Chief Executive Officer Compensation, and Firm Performance. Journal of Financial Economics, 51 (3):371-406.

Daily, C. M., Johnson, J. L., Ellstrand, A. E., and Dalton, D. R. (1998). Compensation Committee Composition as a Determinant of CEO Compensation. Academy of Management Journal, 41 (2):209-220.

DeAngelo, H., and DeAngelo, L. (1989). Proxy Contests and the Governance of Publicly Held Corporations. Journal of Financial Economics, 23 (1):29-59.

Dechow, P. M., and Sloan, R. G. (1991). Executive Incentives and the Horizon Problem: An Empirical Investigation. Journal of Accounting and Economics, 14 (1):51-89.

Dechow, P. M., Huson, M. R., and Sloan, R. G. (1994). The Effect of Restructuring Charges on Executives' Cash Compensation. The Accounting Review, 69 (1):138-156.

Dechow, P. M., Sloan, R. G., and Sweeney, A. P. (1996). Causes and Consequences of Earnings Manipulation: An Analysis of Firms Subject to Enforcement Actions by the SEC. Contemporary Accounting Research, 13 (1):1-36.

Dechow, P. M., Richardson, S. A., and Tuna, I. (2003). Why are Earnings Kinky? An Examination of the Earnings Management Explanation. Review of Accounting Studies, 8 $(2-3): 355-384$.

Demers, E., and Wang, C. (2010). The Impact of CEO Career Concerns on Accruals Based and Real Earnings Management. Working Paper.

Demsetz, H. (1983). Structure of Ownership and the Theory of the Firm. Journal of Law and Economics, 26 (2):375.

Duellman, S., Ahmed, A. S., and Abdel-Meguid, A. M. (2013). An Empirical Analysis of the Effects of Monitoring Intensity on the Relation between Equity Incentives and Earnings Management. Journal of Accounting and Public Policy, 32 (6):495-517.

Duru, A., Iyengar, R. J., and Thevaranjan, A. (2002). The Shielding of CEO Compensation from the Effects of Strategic Expenditures. Contemporary Accounting Research, 19 (2):175-193. 
Fama, E. F. (1980). Agency Problems and the Theory of the Firm. The Journal of Political Economy, 88 (2):288-307.

Fama, E. F., and Jensen, M. C. (1983). Separation of Ownership and Control. Journal of Law and Economics, 26 (2):301-325.

Fama, E. F., and French, K. R. (1997). Industry Costs of Equity. Journal of Financial Economics, 43 (2):153-193.

Ferris, S. P., Jagannathan, M., and Pritchard, A. C. (2003). Too Busy to Mind the Business? Monitoring by Directors with Multiple Board Appointments. The Journal of Finance, 58 (3):1087-1112.

Fich, E. M., and Shivdasani, A. (2006). Are Busy Boards Effective Monitors? The Journal of Finance, 61 (2):689-724.

Finkelstein, S., and Hambrick, D. C. (1989). Chief Executive Compensation: A Study of the Intersection of Markets and Political Processes. Strategic Management Journal, 10 (2):121-134.

Finkelstein, S. (1992). Power in Top Management Teams: Dimensions, Measurement, and Validation. Academy of Management Journal, 35 (3):505-538.

Gaver, J. J., and Gaver, K. M. (1998). The Relation between Nonrecurring Accounting Transactions and CEO Cash Compensation. The Accounting Review, 73 (2):235-253.

Gibbons, R. and Murphy, K. J. (1992), Does Executive Compensation Affect Investment? Journal of Applied Corporate Finance, 5:99-109.

Gilson, S. C. (1990). Bankruptcy, Boards, Banks, and Blockholders: Evidence on Changes in Corporate Ownership and Control When Firms Default. Journal of Financial Economics, 27 (2):355-387.

Gompers, P. A., Ishii, J. L., and Metrick, A. (2001). Corporate Governance and Equity Prices. The Quarterly Journal of Economics, 118 (1):107-155.

Grinstein, Y., and Hribar, P. (2004). CEO Compensation and Incentives: Evidence from M\&A Bonuses. Journal of Financial Economics, 73 (1):119-143.

Hackman, J. R. (1990). Groups that Work (and Those that Don't). San Francisco: JosseyBass.

Harford, J. (2003). Takeover Bids and Target Directors' Incentives: The Impact of a Bid on Directors' Wealth and Board Seats. Journal of Financial Economics, 69 (1):51-83.

Hermalin, B. E., and Weisbach, M. S. (1998). Endogenously Chosen Boards of Directors and Their Monitoring of the CEO. American Economic Review, 88 (1):96-118. 
Hermanson, D. R., Tompkins, J. G., Veliyath, R., and Ye, Z. S. (2012). The Compensation Committee Process. Contemporary Accounting Research, 29 (3):666-709.

Hill, C. W., and Phan, P. (1991). CEO Tenure as a Determinant of CEO Pay. Academy of Management Journal, 34 (3):707-717.

Himmelberg, C. P., and Petersen, B. C. (1994). R \& D and Internal Finance: A Panel Study of Small Firms in High-tech Industries. The Review of Economics and Statistics, 76 (1):38-51.

Hölmstrom, B. (1979). Moral hazard and observability. The Bell Journal of Economics, 10 (1):74-91.

Huergo, E., and Jaumandreu, J. (2004). How Does Probability of Innovation Change with Firm Age? Small Business Economics, 22 (3-4):193-207.

Huson, M. R., Tian, Y., Wiedman, C. I., and Wier, H. A. (2011). Compensation Committees' Treatment of Earnings Components in CEOs' Terminal Years. The Accounting Review, 87 (1):231-259.

Hwang, B. H., and Kim, S. (2009). It Pays to Have Friends. Journal of Financial Economics, 93 (1):138-158.

Jensen, M. C. (1993). The Modern Industrial Revolution, Exit, and the Failure of Internal Control Systems. The Journal of Finance, 48 (3):831-880.

Jensen, M. C., and Meckling, W. H. (1976). Theory of the Firm: Managerial Behavior, Agency Costs, and Ownership Structure. Journal of Financial Economics, 3 (4):305-360.

Jiang, J., Petroni, K. R., and Wang, I. Y. (2010). CFOs and CEOs: Who Have the Most Influence on Earnings Management? Journal of Financial Economics, 96 (3):513-526.

Kaplan, S. N., and Reishus, D. (1990). Outside Directorships and Corporate Performance. Journal of Financial Economics, 27 (2):389-410.

Karamanou, I., and Vafeas, N. (2005). The Association between Corporate Boards, Audit Committees, and Management Earnings Forecasts: An Empirical Analysis. Journal of Accounting Research, 43 (3):453-486.

Katz, R. (1982). The Effects of Group Longevity on Project Communication and Performance. Administrative Science Quarterly, 27 (1):81-104.

Klein, A. (2002a). Audit Committee, Board of Director Characteristics, and Earnings Management. Journal of Accounting and Economics, 33 (3):375-400.

Klein, A. (2002b). Economic Determinants of Audit Committee Independence. The Accounting Review, 77 (2):435-452. 
Kalyta, P. (2009). Accounting Discretion, Horizon Problem, and CEO Retirement Benefits. The Accounting Review, 84 (5):1553-1573.

Laksmana, I. (2008). Corporate Board Governance and Voluntary Disclosure of Executive Compensation Practices. Contemporary Accounting Research, 25 (4):1147-82.

Lambert, R. A., and Larcker, D. F. (1987). An Analysis of the Use of Accounting and Market Measures of Performance in Executive Compensation Contracts. Journal of Accounting Research, 25:85-125.

Lambert, R. A., Larcker, D. F., and Weigelt, K. (1993). The Structure of Organizational Incentives. Administrative Science Quarterly, 38 (3):438-461.

Lewellen, W., Loderer, C., and Martin, K. (1987). Executive Compensation and Executive Incentive Problems: An Empirical Analysis. Journal of Accounting and Economics, 9 (3):287-310.

Lipton, M., and Lorsch, J. W. (1992). A Modest Proposal for Improved Corporate Governance. The Business Lawyer, 48:59-77.

Lundstrum, L. L. (2002). Corporate Investment Myopia: a Horserace of the Theories. Journal of Corporate Finance, 8 (4):353-371.

Mace, M. L. (1971). Directors: Myth and Reality. Boston: Harvard Business School Press.

Murphy, K. J. (1985). Corporate Performance and Managerial Remuneration: An Empirical Analysis. Journal of Accounting and Economics, 7 (1):11-42.

Murphy, K. J., and Zimmerman, J. L. (1993). Financial Performance Surrounding CEO Turnover. Journal of Accounting and Economics, 16 (1):273-315.

Naveen, L. (2006). Organizational Complexity and Succession Planning. Journal of Financial and Quantitative Analysis, 41 (03):661-683.

Nelson, J., Gallery, G., and Percy, M. (2010). Role of Corporate Governance in Mitigating the Selective Disclosure of Executive Stock Option Information. Accounting and Finance, 50 (3):685-717.

Newman, H. A., and Mozes, H. A. (1999). Does the Composition of the Compensation Committee Influence CEO Compensation Practices? Financial Management 28 (3):41-53.

O'Reilly III, C. A., Main, B. G., and Crystal, G. S. (1988). CEO Compensation as Tournament and Social Comparison: A Tale of Two Theories. Administrative Science Quarterly, 33 (2):257-274.

O'Reilly III, C. A., and Main, B. G. (2007). Setting the CEO's Pay: It's More Than Simple Economics. Organizational Dynamics, 36 (1):1-12. 
Pourciau, S. (1993). Earnings Management and Nonroutine Executive Changes. Journal of Accounting and Economics, 16 (1):317-336.

Rosenstein, S., and Wyatt, J. G. (1997). Inside Directors, Board Effectiveness, and Shareholder Wealth. Journal of Financial Economics, 44 (2):229-250.

Sapp, S. G. (2008). The Impact of Corporate Governance on Executive Compensation. European Financial Management, 14 (4):710-746.

Shivdasani, A. (1993). Board Composition, Ownership Structure, and Hostile Takeovers. Journal of Accounting and Economics, 16 (1):167-198.

Shivdasani, A., and Yermack, D. (1999). CEO Involvement in the Selection of New Board Members: An Empirical Analysis. The Journal of Finance, 54 (5):1829-1853.

Smith, C. W., and Watts, R. L. (1982). Incentive and Tax Effects of Executive Compensation Plans. Australian Journal of Management, 7 (2):139-157.

Smith Jr, C. W., and Watts, R. L. (1992). The Investment Opportunity Set and Corporate Financing, Dividend, and Compensation Policies. Journal of Financial Economics, 32 (3):263-292.

Shivdasani, A., and D. Yermack. 1999. CEO Involvement in the Selection of New Board Members: An Empirical Analysis. Journal of Finance, 56:1829-1853.

Steiner, I. D. (2007). Group Process and Productivity. Academic Press, New York, NY.

Sun, J., and Cahan, S. (2009). The Effect of Compensation Committee Quality on the Association between CEO Cash Compensation and Accounting Performance. Corporate Governance: An International Review, 17 (2):193-207.

Sun, J., Cahan, S. F., and Emanuel, D. (2009). Compensation Committee Governance Quality, Chief Executive Officer Stock Option Grants, and Future Firm Performance. Journal of Banking and Finance, 33 (8):1507-1519.

Sun, J., and Cahan, S. F. (2012). The Economic Determinants of Compensation Committee Quality. Managerial Finance, 38 (2):188-205.

Sundaram, R. K., and Yermack, D. L. (2007). Pay Me Later: Inside Debt and Its Role in Managerial Compensation. The Journal of Finance, 62 (4):1551-1588.

Uzun, H., Szewczyk, S. H., and Varma, R. (2004). Board Composition and Corporate Fraud. Financial Analysts Journal, 60 (3):33-43.

Vafeas, N. (2003a). Length of Board Tenure and Outside Director Independence. Journal of Business Finance and Accounting, 30 (7-8):1043-1064. 
Vafeas, N. (2003b). Further Evidence on Compensation Committee Composition as a Determinant of CEO Compensation. Financial Management, 32 (2):53-70.

Wade, J., O'Reilly III, C. A., and Chandratat, I. (1990). Golden Parachutes: CEOs and the Exercise of Social Influence. Administrative Science Quarterly, 35:587-603.

Wang, S., and D'Souza, J. (2006). Earnings Management: The Effect of Accounting Flexibility on R\&D Investment Choices. Johnson School Research Paper Series, 1:33-75.

Weisbach, M. S. (1988). Outside Directors and CEO Turnover. Journal of Financial Economics, 20:431-460.

Wells, P. (2002). Earnings Management Surrounding CEO Changes. Accounting and Finance, 42 (2):169-193.

Westphal, J. D., and Zajac, E. J. (1995). Who Shall Govern? CEO/Board Power, Demographic Similarity, and New Director Selection. Administrative Science Quarterly, 40 (1):60-83.

Yermack, D. (1996). Higher Market Valuation of Companies with a Small Board of Directors. Journal of Financial Economics, 40 (2):185-211. 
TABLE 1 Sample Description

Panel A: Sample Selection

Total firm-year observations in Riskmetrics for the period of 1998-2011

n

Firm-year observations without CEO compensation data from Execucomp

21,681

Firm-year observations missing the date when CEO was hired

Firms in the financial service sector

Firm-year observations missing Compustat inputs to calculate sales, return, and ROA

Firm-year observations missing number of shares held by CEO

Firm-year observations at the top and bottom one percent of all continuous variables

Final Sample

13,606

This panel presents the information about the sample selection procedure.

\section{Panel B: Industry Composition}




\begin{tabular}{|c|c|c|}
\hline Industry & $\mathbf{n}$ & $\begin{array}{l}\text { The percentage of compensation committees } \\
\text { dominated by co-opted directors }\end{array}$ \\
\hline Candy and Soda & 29 & 0.241 \\
\hline Electronic Equipment & 366 & 0.268 \\
\hline Electrical Equipment & 184 & 0.359 \\
\hline Shipbuilding, Railroad Eq & 61 & 0.295 \\
\hline Petroleum and Natural Gas & 991 & 0.315 \\
\hline Textiles & 84 & 0.345 \\
\hline Consumer Goods & 309 & 0.379 \\
\hline Recreational Products & 88 & 0.375 \\
\hline Precious Metals & 65 & 0.292 \\
\hline Rubber and Plastic Products & 93 & 0.441 \\
\hline Tobacco Products & 24 & 0.333 \\
\hline $\begin{array}{l}\text { Measuring and } \\
\text { Control Equip }\end{array}$ & 318 & 0.399 \\
\hline Chemicals & 485 & 0.419 \\
\hline Entertainment & 95 & 0.421 \\
\hline Wholesale & 1,009 & 0.408 \\
\hline Printing and Publishing & 125 & 0.456 \\
\hline Miscellaneous & 264 & 0.432 \\
\hline Defense & 22 & 0.500 \\
\hline Agriculture & 24 & 0.375 \\
\hline Construction Materials & 319 & 0.433 \\
\hline Automobiles and Trucks & 134 & 0.463 \\
\hline Aircraft & 30 & 0.700 \\
\hline Business Services & 485 & 0.487 \\
\hline Transportation & 545 & 0.448 \\
\hline Food Products & 314 & 0.468 \\
\hline Computers & 1,004 & 0.476 \\
\hline Telecommunications & 160 & 0.475 \\
\hline Alcoholic Beverages & 53 & 0.434 \\
\hline Steel Works, Etc. & 273 & 0.451 \\
\hline Machinery & 664 & 0.480 \\
\hline Medical Equipment & 428 & 0.477 \\
\hline Coal & 611 & 0.516 \\
\hline Retail & 337 & 0.475 \\
\hline Utilities & 256 & 0.449 \\
\hline Pharmaceutical Products & 519 & 0.511 \\
\hline Business Supplies & 78 & 0.449 \\
\hline Personal Services & 1,450 & 0.490 \\
\hline
\end{tabular}


Shipping Containers

0.527

Healthcare

266

0.526

Trading

124

0.565

Apparel

225

0.613

Construction

0.644

Fabricated Products

26

0.769

Nonmetallic Mines

35

0.629

This panel presents the number of firm-year observations in each of Fama-French (1997) 48 industries and the percentage of compensation committees dominated by co-opted directors in each industry.

Panel C: Fiscal Year Composition

\begin{tabular}{ccc}
\hline Fiscal Year & n & $\begin{array}{c}\text { The percentage of compensation committees dominated } \\
\text { by co-opted directors }\end{array}$ \\
\hline 1998 & 927 & 0.436 \\
1999 & 907 & 0.436
\end{tabular}




$\begin{array}{lcc}2000 & 882 & 0.438 \\ 2001 & 938 & 0.425 \\ 2002 & 953 & 0.422 \\ 2003 & 990 & 0.434 \\ 2004 & 1,002 & 0.440 \\ 2005 & 980 & 0.448 \\ 2006 & 973 & 0.464 \\ 2007 & 892 & 0.478 \\ 2008 & 986 & 0.461 \\ 2009 & 1,027 & 0.479 \\ 2010 & 1,079 & 0.475 \\ 2011 & 1,070 & 0.473\end{array}$

This panel displays the number of firm-year observations and the percentage of compensation committees dominated by co-opted directors in each fiscal year between 1998 and 2011. 


\begin{tabular}{|c|c|c|c|c|c|c|}
\hline \multicolumn{7}{|c|}{ Panel D: Descriptive Statistics } \\
\hline Variable & $\mathbf{n}$ & Mean & Std Dev & $\begin{array}{c}\text { Lower } \\
\text { Quartile }\end{array}$ & Median & $\begin{array}{c}\text { Upper } \\
\text { Quartile }\end{array}$ \\
\hline $\ln T \_P A Y$ & 13,606 & 7.99 & 0.94 & 7.31 & 8.00 & 8.65 \\
\hline COOPTED_CC & 13,606 & 0.45 & 0.50 & 0.00 & 0.00 & 1.00 \\
\hline SIZE & 13,606 & 7.45 & 1.40 & 6.46 & 7.35 & 8.40 \\
\hline$R E T$ & 13,606 & 0.05 & 0.41 & -0.22 & 0.02 & 0.26 \\
\hline$R O A$ & 13,606 & 0.14 & 0.08 & 0.09 & 0.13 & 0.19 \\
\hline CEO_TENURE & 13,606 & 6.74 & 6.99 & 2.00 & 5.00 & 9.00 \\
\hline CEO_OWNERSHIP & 13,606 & 15.54 & 36.89 & 0.94 & 2.90 & 10.03 \\
\hline CEO_CHAIR & 13,606 & 0.71 & 0.45 & 0.00 & 1.00 & 1.00 \\
\hline B_INDEPENDENCE & 13,606 & 0.72 & 0.16 & 0.63 & 0.75 & 0.86 \\
\hline B_OWNERSHIP & 13,606 & $63,423.10$ & $93,799.10$ & $8,777.73$ & $25,292.56$ & $73,053.44$ \\
\hline B_SIZE & 13,606 & 9.10 & 2.40 & 7.00 & 9.00 & 11.00 \\
\hline B_FEMALE & 13,606 & 0.65 & 0.48 & 0.00 & 1.00 & 1.00 \\
\hline
\end{tabular}

This panel displays the descriptive statistics. $\ln T_{-} P A Y$ is the natural logarithm of CEO total compensation. CEO total compensation includes salary, bonus, other annual compensation, restricted stock grants, long-term incentive payouts, all other compensation, and value of option grants (EXECUCOMP data item TDC1). It is adjusted to 2003 dollars using Consumer Price Index. COOPTED $C C$ is an indicator variable equal to one if the majority of compensation committee directors are appointed after the incumbent CEO assumes office, and zero otherwise. $S I Z E$ is the natural logarithm of sales. RET is the firm's stock return. ROA is the earnings before extraordinary item divided by total assets. CEO_TENURE is the CEO tenure.

CEO OWNERSHIP is the proportion of the firm's outstanding shares held by the CEO. CEO_CHAIR is an indicator variable equal to one if CEO is the chairman of the board of directors, and zero otherwise. B_INDEPENDENCE is the proportion of outsiders on board of directors. $B$ OWNERSHIP is the proportion of the firm's outstanding shares held by directors on the board. $B_{-} S I Z E$ is the number of directors on the board. $B_{-} F E M A L E$ is an indicator equal to one if at least one of the directors on board is female, and zero otherwise. 


\begin{tabular}{|c|c|c|c|c|c|c|c|c|c|}
\hline \multicolumn{10}{|c|}{ Panel E: Pearson Correlations } \\
\hline & $\ln T \_P A Y$ & SIZE & $R E T$ & $R O A$ & CEO_TENURE & $\begin{array}{c}C E O \_O W N E \\
R S H I P\end{array}$ & $\begin{array}{c}B \_I N D E P E N D \\
E N C E\end{array}$ & $\begin{array}{c}\text { B_OWNER } \\
\text { SHIP }\end{array}$ & B_SIZE \\
\hline SIZE & 0.60 & & & & & & & & \\
\hline RET & 0.04 & -0.02 & & & & & & & \\
\hline$R O A$ & 0.14 & 0.11 & 0.06 & & & & & & \\
\hline CEO_TENURE & -0.06 & -0.10 & -0.00 & 0.01 & & & & & \\
\hline CEO_OWNERSHIP & -0.21 & -0.15 & 0.00 & 0.06 & 0.39 & & & & \\
\hline B_INDEPENDENCE & 0.18 & 0.18 & 0.02 & -0.05 & -0.11 & -0.24 & & & \\
\hline B_OWNERSHIP & -0.22 & -0.18 & 0.02 & 0.04 & 0.17 & 0.47 & -0.41 & & \\
\hline B_SIZE & 0.31 & 0.53 & -0.03 & 0.02 & -0.11 & -0.15 & 0.05 & -0.04 & \\
\hline B_FEMALE & 0.25 & 0.41 & -0.01 & 0.05 & -0.14 & -0.14 & 0.2 & -0.14 & 0.47 \\
\hline \multicolumn{10}{|c|}{$\begin{array}{l}\text { This panel displays the Pearson correlations. } \ln T \text { PAY is the natural logarithm of CEO total compensation. CEO total compensation } \\
\text { includes salary, bonus, other annual compensation, restricted stock grants, long-term incentive payouts, all other compensation, and } \\
\text { value of option grants (EXECUCOMP data item TDC1). It is adjusted to } 2003 \text { dollars using Consumer Price Index. SIZE is the natural } \\
\text { logarithm of sales. RET is the firm's stock return. ROA is the earnings before extraordinary item divided by total assets. CEO_TENURE } \\
\text { is the CEO tenure. CEO_OWNERSHIP is the proportion of the firm's outstanding shares held by CEO. B_INDEPENDENCE is the } \\
\text { proportion of outsiders on the board of directors. } B \text { OOWNERSHIP is the proportion of the firm's outstanding shares held by directors on } \\
\text { the board. } B \text { SIZE is the number of directors on the board. B_FEMALE is an indicator equal to one if at least one of the directors on the } \\
\text { board is female, and zero otherwise. Correlations with p-values equal to or lower than } 0.05 \text { are in boldface. }\end{array}$} \\
\hline
\end{tabular}



TABLE 2 Regression Results: The effect of compensation committee dominated by co-opted
directors on CEO compensation

\begin{tabular}{|c|c|c|c|}
\hline \multicolumn{4}{|c|}{ Dependent Variable $=\ln T \_P A Y$} \\
\hline Variable & Predicted Sign & Coefficient & p-value \\
\hline Intercept & & 4.880 & $(<0.01)$ \\
\hline COOPTED_CC & + & 0.071 & $(<0.01)$ \\
\hline SIZE & + & 0.374 & $(<0.01)$ \\
\hline$R E T$ & + & 0.106 & $(<0.01)$ \\
\hline$R O A$ & + & 1.132 & $(<0.01)$ \\
\hline CEO_TENURE & + & 0.001 & $(0.32)$ \\
\hline CEO_OWNERSHIP & $?$ & -0.003 & $(<0.01)$ \\
\hline CEO_CHAIR & + & 0.130 & $(<0.01)$ \\
\hline B_INDEPENDENCE & $?$ & 0.207 & $(<0.01)$ \\
\hline B_OWNERSHIP & - & -0.000 & $(<0.01)$ \\
\hline B_SIZE & + & 0.002 & $(0.32)$ \\
\hline B_FEMALE & $?$ & -0.036 & $(0.03)$ \\
\hline Observations & & \multicolumn{2}{|c|}{13,606} \\
\hline $\mathrm{R}^{2}$ & & \multicolumn{2}{|c|}{$40.15 \%$} \\
\hline
\end{tabular}

This table presents regression results for model (2). $\ln T_{-} P A Y$ is the natural logarithm of CEO total compensation. CEO total compensation includes salary, bonus, other annual compensation, restricted stock grants, long-term incentive payouts, all other compensation, and value of option grants (EXECUCOMP data item TDC1). It is adjusted to 2003 dollars using Consumer Price Index.COOPTED_CC is an indicator variable equal to one if the majority of compensation committee directors are appointed after the incumbent CEO assumes office, and zero otherwise. $S I Z E$ is the natural logarithm of sales. RET is the firm's stock return. ROA is the earnings before extraordinary item divided by total assets. CEO_TENURE is the CEO tenure.

CEO_OWNERSHIP is the proportion of the firm's outstanding shares held by CEO. CEO_CHAIR is an indicator variable equal to one if $\mathrm{CEO}$ is the chairman of the board of directors, and zero otherwise. B_INDEPENDENCE is the proportion of outsiders on the board of directors.

$B \_O W N E R S H I P$ is the proportion of the firm's outstanding shares held by directors on the board. $B \_S I Z E$ is the number of directors on the board. B_FEMALE is an indicator equal to one if at least one of the directors on the board is female, and zero otherwise. The p-values are presented in parentheses and are one-tailed for coefficients that have the predicted sign and two-tailed for those without a predicted sign or those that do not have the predicted sign. The standard errors are heteroskedasticity robust, clustered by firm and year. For the sake of brevity, we do not report coefficient estimates for year indicators and $\mathrm{G}$ index dummies. 
TABLE 3 Descriptive Statistics and Pearson Correlations for the R\&D Test

\begin{tabular}{lcccccc}
\hline \multicolumn{2}{l}{ Panel A : Descriptive Statistics } & \multicolumn{7}{l}{ Lower } \\
\hline Variable & $\mathrm{n}$ & Mean & Std Dev & $\begin{array}{c}\text { Median } \\
\text { Quartile }\end{array}$ & $\begin{array}{c}\text { Upper } \\
\text { Quartile }\end{array}$ \\
\hline$R D$ & 5,599 & 0.04 & 0.05 & 0.00 & 0.03 & 0.07 \\
HORIZON & 5,599 & 0.08 & 0.27 & 0.00 & 0.00 & 0.00 \\
COOPTED_CC & 5,599 & 0.62 & 0.49 & 0.00 & 1.00 & 1.00 \\
TOBINS_Q & 5,599 & 2.07 & 1.13 & 1.32 & 1.72 & 2.46 \\
LAG_RET & 5,599 & 0.10 & 0.45 & -0.21 & 0.05 & 0.31 \\
FCF & 5,599 & 0.11 & 0.13 & 0.05 & 0.11 & 0.17 \\
ROA & 5,599 & 0.13 & 0.10 & 0.07 & 0.12 & 0.19 \\
SIZE & 5,599 & 7.29 & 1.43 & 6.22 & 7.12 & 8.23 \\
FIRM_AGE & 5,599 & 26.15 & 16.64 & 12.00 & 20.00 & 41.00 \\
EQUITY_INCENTIVES & 5,599 & 629.56 & $1,288.63$ & 88.13 & 227.47 & 605.18 \\
INDUSTRY_RD & 5,599 & 0.15 & 0.17 & 0.01 & 0.12 & 0.20
\end{tabular}

This panel reports the descriptive statistics. $R D$ is the $\mathrm{R} \& \mathrm{D}$ expense scaled by total assets. COOPTED_CC is an indicator variable equal to one if the majority of compensation committee directors are appointed after the incumbent CEO assumes office, and zero otherwise. HORIZON is an indicator variable equal to one if CEOs are in each of the final two years prior to their retirement, and zero otherwise. TOBINS_Q is calculated as the market value of equity plus the book value of debt, all scaled by total assets. $L A G_{-} R E T$ is the firm's stock return from previous year. $F C F$ is the operating cash flows plus R\&D expense minus capital expenditures, all scaled by sales. $R O A$ is operating net income before $\mathrm{R} \& \mathrm{D}$ expense scaled by assets. SIZE is the natural logarithm of total assets at the beginning of the current year. FIRM_AGE is the number of years between the current year and the first year the company listed on Compustat.

EQUITY INCENTIVES is the CEO's dollar wealth increase from a $1 \%$ change in stock price, as measured in Core and Guay (2002). INDUSTRY_RD is the average R\&D expenditures of other firms in the same 2-digit SIC industry. 


\begin{tabular}{|c|c|c|c|c|c|c|c|c|}
\hline \multicolumn{9}{|c|}{ Panel B: Pearson Correlations } \\
\hline & $R D$ & TOBINS_Q & $L A G \_R E T$ & $F C F$ & $R O A$ & SIZE & FIRM_AGE & EQUITY_INCENTIVES \\
\hline TOBINS_Q & 0.26 & & & & & & & \\
\hline$L A G \_R E T$ & 0.00 & 0.12 & & & & & & \\
\hline$F C F$ & -0.43 & 0.17 & 0.03 & & & & & \\
\hline$R O A$ & 0.33 & 0.58 & 0.17 & 0.25 & & & & \\
\hline SIZE & -0.19 & -0.08 & -0.05 & 0.16 & -0.07 & & & \\
\hline FIRM_AGE & -0.19 & -0.15 & -0.05 & 0.03 & -0.07 & 0.51 & & \\
\hline EQUITY_INCENTIVES & 0.02 & 0.35 & 0.04 & 0.12 & 0.14 & 0.22 & -0.05 & \\
\hline INDUSTRY_RD & 0.31 & 0.09 & 0.02 & -0.09 & 0.15 & 0.01 & 0.08 & -0.03 \\
\hline
\end{tabular}

This panel reports the Pearson correlations. $R D$ is the $\mathrm{R} \& \mathrm{D}$ expense scaled by total assets. TOBINS $Q$ is calculated as the market value of equity plus the book value of debt, all scaled by total assets. $L A G_{-} R E T$ is the firm's stock return from previous year. FCF is the operating cash flows plus R\&D expense minus capital expenditures, all scaled by sales. ROA is operating net income before R\&D expense scaled by assets. SIZE is the natural logarithm of total assets at the beginning of the current year. FIRM_AGE is the number of years between the current year and the first year the company listed on Compustat. EQUITY_INCENTIVES is the CEO's dollar wealth increase from a 1\% change in stock price, as measured in Core and Guay (2002). INDUSTRY_RD is the average R\&D expenditures of other firms in the same 2-digit SIC industry. Correlations with p-values equal to or lower than 0.05 are in boldface. 


\begin{tabular}{|c|c|c|c|}
\hline \multicolumn{4}{|c|}{$\begin{array}{l}\text { TABLE } 4 \text { Regression Results: The effect of whether compensation committees are } \\
\text { dominated by co-opted directors on the association between R\&D spending and CEO } \\
\text { horizon problem }\end{array}$} \\
\hline \multicolumn{4}{|c|}{ Dependent Variable $=R D$} \\
\hline Variable & Predicted Sign & Coefficient & P-value \\
\hline Intercept & & 0.028 & $(<0.01)$ \\
\hline HORIZON & $?$ & 0.003 & $(0.27)$ \\
\hline COOPTED_CC & $?$ & 0.003 & $(<0.01)$ \\
\hline HORIZON $\times$ COOPTED_CC & - & -0.006 & $(0.03)$ \\
\hline$T O B I N S \_Q$ & + & 0.005 & $(<0.01)$ \\
\hline$L A G \_R E T$ & + & -0.007 & $(<0.01)$ \\
\hline$F C F$ & + & -0.198 & $(<0.01)$ \\
\hline$R O A$ & - & 0.187 & $(<0.01)$ \\
\hline SIZE & $?$ & 0.000 & $(0.80)$ \\
\hline FIRM_AGE & - & -0.000 & $(<0.01)$ \\
\hline EQUITY_INCENTIVES & + & -0.000 & $(0.30)$ \\
\hline INDUSTRY_RD & + & 0.064 & $(<0.01)$ \\
\hline Number of observations & & \multicolumn{2}{|c|}{5,599} \\
\hline $\mathrm{R}^{2}$ & & \multicolumn{2}{|c|}{$47,33 \%$} \\
\hline \multicolumn{4}{|c|}{$\begin{array}{l}\text { The table presents OLS regression results for model (3). } R D \text { is the R\&D expense scaled by total } \\
\text { assets. COOPTED_CC is an indicator variable equal to one if the majority of compensation } \\
\text { committee directors are appointed after the incumbent CEO assumes office, and zero otherwise. } \\
H O R I Z O N \text { is an indicator variable equal to one if CEOs are in each of the final two years prior to } \\
\text { their retirement, and zero otherwise. TOBINS_Q is calculated as the market value of equity plus } \\
\text { the book value of debt, all scaled by total assets. } L A G \_R E T \text { is the firm's stock return from } \\
\text { previous year. } F C F \text { is the operating cash flows plus R\&D expense minus capital expenditures, all } \\
\text { scaled by sales. } R O A \text { is operating net income before R\&D expense scaled by assets. SIZE is the } \\
\text { natural logarithm of total assets at the beginning of the current year. FIRM_AGE is the number of } \\
\text { years between the current year and the first year the company listed on Compustat. } \\
E Q U I T Y \text { INCENTIVES is the CEO's dollar wealth increase from a } 1 \% \text { change in stock price, as } \\
\text { measured in Core and Guay (2002). INDUSTRY_RD is the average R\&D expenditures of other } \\
\text { firms in the same } 2 \text {-digit SIC industry. The p-values are presented in parentheses and are one- } \\
\text { tailed for coefficients that have the predicted sign and two-tailed for those without a predicted } \\
\text { sign or those that do not have the predicted sign. The standard errors are heteroskedasticity } \\
\text { robust, clustered by firm and year. For the sake of brevity, we do not report coefficient estimates } \\
\text { for year indicators. }\end{array}$} \\
\hline
\end{tabular}


TABLE 5 Descriptive Statistics and Pearson Correlations for the Discretionary Accruals Test

\begin{tabular}{|c|c|c|c|c|c|c|}
\hline \multicolumn{7}{|c|}{ Panel A : Descriptive Statistics } \\
\hline Variable & $\mathrm{n}$ & Mean & Std Dev & $\begin{array}{c}\text { Lower } \\
\text { Quartile }\end{array}$ & Median & $\begin{array}{c}\text { Upper } \\
\text { Quartile }\end{array}$ \\
\hline$D A$ & 8,541 & 0.01 & 0.84 & -0.07 & 0.01 & 0.12 \\
\hline HORIZON & 8,541 & 0.08 & 0.27 & 0.00 & 0.00 & 0.00 \\
\hline COOPTED_CC & 8,541 & 0.62 & 0.48 & 0.00 & 1.00 & 1.00 \\
\hline EQUITY_INCENTIVES & 8,541 & 0.25 & 0.22 & 0.09 & 0.17 & 0.34 \\
\hline SIZE & 8,541 & 7.38 & 1.42 & 6.31 & 7.23 & 8.32 \\
\hline STD_CASHFLOW & 8,541 & 0.04 & 0.03 & 0.02 & 0.04 & 0.06 \\
\hline$S T D \_R E V$ & 8,541 & 0.14 & 0.10 & 0.06 & 0.11 & 0.18 \\
\hline STD_SALESGROWTH & 8,541 & 0.19 & 0.17 & 0.08 & 0.13 & 0.24 \\
\hline OLDFIRM & 8,541 & 0.55 & 0.50 & 0.00 & 1.00 & 1.00 \\
\hline LEVERAGE & 8,541 & 0.22 & 0.16 & 0.06 & 0.22 & 0.34 \\
\hline
\end{tabular}

This panel presents the descriptive statistics. $D A$ is the discretionary accruals. COOPTED_CC is an indicator variable equal to one if the majority of compensation committee directors are appointed after the incumbent $\mathrm{CEO}$ assumes office, and zero otherwise. HORIZON is an indicator variable equal to one if CEOs are in each of the final two years prior to their retirement, and zero otherwise. EQUITY_INCENTIVES is the dollar change in CEO's wealth from a $1 \%$ change in stock price, as measured in Core and Guay (2002), then normalized by the sum of the dollar change, salary and bonus. SIZE is the natural logarithm of total assets at the beginning of the current year. STD_CASHFLOW is the standard deviation of cash flows from operations deflated by total assets over the current and previous four years. $S T D \_R E V$ is the standard deviation of sales deflated by total assets over the current and previous four years. STD_SALESGROWTH is the standard deviation of sales growth over the current and previous four years. OLDFIRM equals one if a firm is listed on Compustat for more than 20 years, and zero otherwise. LEVERAGE is total liabilities deflated by total assets. 


\begin{tabular}{|c|c|c|c|c|c|c|c|}
\hline \multicolumn{8}{|c|}{ Panel B : Pearson Correlations } \\
\hline & $D A$ & EQUITY_INCENTIVES & SIZE & STD_CASHFLOW & $S T D \_R E V$ & STD_SALESGROWTH & OLDFIRM \\
\hline EQUITY_INCENTIVES & -0.01 & & & & & & \\
\hline SIZE & 0.02 & 0.04 & & & & & \\
\hline STD_CASHFLOW & -0.02 & -0.01 & -0.31 & & & & \\
\hline$S T D \_R E V$ & 0.01 & -0.02 & -0.19 & 0.36 & & & \\
\hline STD_SALESGROWTH & 0.01 & -0.00 & -0.04 & 0.27 & 0.24 & & \\
\hline OLDFIRM & 0.03 & -0.15 & 0.36 & -0.17 & -0.08 & -0.14 & \\
\hline LEVERAGE & 0.02 & -0.2 & 0.38 & -0.19 & -0.07 & 0.05 & 0.18 \\
\hline
\end{tabular}

This panel presents the Pearson correlations. DA is the discretionary accruals. EQUITY INCENTIVES is the dollar change in CEO's wealth from a $1 \%$ change in stock price, as measured in Core and Guay (2002), then normalized by the sum of the dollar change, salary and bonus. SIZE is the natural logarithm of total assets at the beginning of the current year. STD_CASHFLOW is the standard deviation of cash flows from operations deflated by total assets over the current and previous four years. STD_REV is the standard deviation of sales deflated by total assets over the current and previous four years. STD_SALESGROWTH is the standard deviation of sales growth over the current and previous four years. OLDFIRM equals one if a firm is listed on Compustat for more than 20 years, and zero otherwise.

LEVERAGE is total liabilities deflated by total assets. Correlations with p-values equal to or lower than 0.05 are in boldface. Correlations with p-values equal to or lower than 0.05 are in boldface. 


\begin{tabular}{|c|c|c|c|}
\hline \multicolumn{4}{|c|}{$\begin{array}{l}\text { TABLE } 6 \text { Regression Results: The effect of whether compensation committees are } \\
\text { dominated by co-opted directors on the association between discretionary accruals and } \\
\text { CEO horizon problem }\end{array}$} \\
\hline \multicolumn{4}{|c|}{ Dependent Variable $=D A$} \\
\hline Variable & Predicted Sign & Coefficient & P-value \\
\hline Intercept & & 0.213 & $(0.06)$ \\
\hline HORIZON & + & -0.041 & $(0.38)$ \\
\hline COOPTED_CC & $?$ & -0.053 & $(0.01)$ \\
\hline HORIZON $\times$ COOPTED_CC & + & 0.103 & $(0.05)$ \\
\hline EQUITY_INCENTIVES & + & 0.048 & $(0.17)$ \\
\hline SIZE & - & -0.006 & $(0.23)$ \\
\hline STD_CASHFLOW & $?$ & -0.807 & $(0.06)$ \\
\hline$S T D \_R E V$ & $?$ & 0.147 & $(0.18)$ \\
\hline STD_SALESGROWTH & $?$ & -0.005 & $(0.94)$ \\
\hline OLDFIRM & $?$ & 0.022 & $(0.33)$ \\
\hline LEVERAGE & $?$ & -0.001 & $(0.99)$ \\
\hline MARKETTOBOOK & $?$ & -0.005 & $(0.29)$ \\
\hline Number of observations & & \multicolumn{2}{|c|}{8,541} \\
\hline $\mathrm{R}^{2}$ & & \multicolumn{2}{|c|}{$4.66 \%$} \\
\hline
\end{tabular}

The table presents OLS regression results for model (4). $D A$ is the discretionary accruals. COOPTED_CC is an indicator variable equal to one if the majority of compensation committee directors are appointed after the incumbent CEO assumes office, and zero otherwise. HORIZON is an indicator variable equal to one if CEOs are in each of the final two years prior to their retirement, and zero otherwise. EQUITY INCENTIVES is the dollar change in CEO's wealth from a $1 \%$ change in stock price, as measured in Core and Guay (2002), then normalized by the sum of the dollar change, salary and bonus. SIZE is the natural logarithm of total assets at the beginning of the current year. STD_CASHFLOW is the standard deviation of cash flows from operations deflated by total assets over the current and previous four years. STD_REV is the standard deviation of sales deflated by total assets over the current and previous four years.

STD_SALESGROWTH is the standard deviation of sales growth over the current and previous four years. OLDFIRM equals one if a firm is listed on Compustat for more than 20 years, and zero otherwise. LEVERAGE is total liabilities deflated by total assets. MARKETTOBOOK represents deciles of market value of assets divided by the book value of assets ranked within each year. The p-values are presented in parentheses and are one-tailed for coefficients that have the predicted sign and two-tailed for those without a predicted sign or those that do not have the predicted sign. The standard errors are heteroskedasticity robust, clustered by firm and year. For the sake of brevity, we do not report coefficient estimates for year indicators, G_index indicators, exchange indicators and industry indicators. 


\section{TABLE 7 Descriptive Statistics and Pearson Correlations for the Change in CEO}

Compensation Test

\begin{tabular}{|c|c|c|c|c|c|c|}
\hline \multicolumn{7}{|c|}{ Panel A : Descriptive Statistics } \\
\hline Variable & $\mathrm{n}$ & Mean & Std Dev & $\begin{array}{c}\text { Lower } \\
\text { Quartile }\end{array}$ & Median & $\begin{array}{c}\text { Upper } \\
\text { Quartile }\end{array}$ \\
\hline$\triangle \ln C \_P A Y$ & 8,950 & -0.02 & 0.33 & -0.08 & 0.01 & 0.11 \\
\hline$\triangle \ln T_{-} P A Y$ & 8,889 & 0.05 & 0.75 & -0.20 & 0.04 & 0.32 \\
\hline$\triangle \ln L \_P A Y$ & 8,763 & 0.19 & 3.27 & -0.29 & 0.07 & 0.51 \\
\hline$\triangle R O A$ & 8,950 & 0.01 & 0.06 & -0.01 & 0.01 & 0.03 \\
\hline$A D J \quad R E T$ & 8,950 & -0.01 & 0.09 & -0.06 & -0.01 & 0.04 \\
\hline$P O S \_\triangle D A$ & 8,950 & 0.33 & 0.94 & 0.00 & 0.00 & 0.16 \\
\hline$N E G \_\Delta D A$ & 8,950 & -0.35 & 0.98 & -0.17 & -0.00 & 0.00 \\
\hline HORIZON & 8,950 & 0.08 & 0.27 & 0.00 & 0.00 & 0.00 \\
\hline COOPTED_CC & 8,950 & 0.62 & 0.49 & 0.00 & 1.00 & 1.00 \\
\hline EQUITY_INCENTIVES & 8,950 & 601.68 & 1168.79 & 79.31 & 212.20 & 559.31 \\
\hline$\Delta R D$ & 5,380 & 0.01 & 0.02 & 0.00 & 0.00 & 0.01 \\
\hline
\end{tabular}

This panel presents the descriptive statistics. $\triangle \ln C_{-} P A Y$ is the change in the natural logarithm of CEO salary and bonus. $\triangle \ln T P A Y$ is the change in the natural logarithm of CEO total compensation (EXECUCOMP data item TDC1). $\triangle \operatorname{lnL} P A Y Y$ is the change in natural logarithm of CEO long-term compensation, which is defined as the sum of restricted stock grants, value of option grants, and long-term incentive payouts. All the compensation measures are adjusted to 2003 dollars using Consumer Price Index. $\triangle R O A$ is the change in earnings before extraordinary items, scaled by lagged total assets. $A D J \quad R E T$ is the firm's annual size-adjusted stock return. $P O S \_\triangle D A$ is the positive changes in discretionary accruals. $N E G_{-} \triangle D A$ is the negative changes in discretionary accruals. $H O R I Z O N$ is an indicator variable equal to one if CEOs are in each of the final two years prior to their retirement, and zero otherwise. COOPTED_CC is an indicator variable equal to one if the majority of compensation committee directors are appointed after the incumbent CEO assumes office, and zero otherwise. EQUITY_INCENTIVES is the CEO's dollar wealth increase from a $1 \%$ change in stock price, as measured in Core and Guay (2002). $\triangle R D$ is the change in $R \& D$ expenditures, scaled by lagged total assets. 
Panel B: Pearson Correlations

\begin{tabular}{|c|c|c|c|c|c|}
\hline & $\triangle \ln C_{-} P A Y$ & $\triangle \ln T_{-} P A Y$ & $\triangle \ln L \_P A Y$ & $\triangle R O A$ & $A D J \_R E T$ \\
\hline$\triangle \ln T_{-} P A Y$ & 0.2 & & & & \\
\hline$\triangle \ln L \_P A Y$ & -0.00 & 0.5 & & & \\
\hline$\triangle R O A$ & 0.19 & 0.14 & 0.04 & & \\
\hline$A D J \_R E T$ & 0.05 & 0.04 & 0.02 & 0.02 & \\
\hline EQUITY INCENTIVES & 0.03 & 0.03 & 0.01 & 0.08 & 0.03 \\
\hline
\end{tabular}

This panel presents the Pearson correlations. $\triangle \ln C_{-} P A Y$ is the change in the natural logarithm of CEO salary and bonus. $\triangle \ln T \_P A Y$ is the change in the natural logarithm of CEO total compensation (EXECUCOMP data item TDC1). $\triangle \ln L \_P A Y$ is the change in natural logarithm of CEO long-term compensation, which is defined as the sum of restricted stock grants, value of option grants, and long-term incentive payouts. All the compensation measures are adjusted to 2003 dollars using Consumer Price Index. $\triangle R O A$ is the change in earnings before extraordinary items, scaled by lagged total assets. $A D J \_R E T$ is the firm's annual size-adjusted stock return. EQUITY INCENTIVES is the CEO's dollar wealth increase from a $1 \%$ change in stock price, as measured in Core and Guay (2002). 


\begin{tabular}{|c|c|c|c|c|c|c|c|}
\hline \multicolumn{8}{|c|}{$\begin{array}{l}\text { TABLE } 8 \text { Regression Results: The effect of whether compensation committees are } \\
\text { dominated by co-opted directors and whether CEOs are approaching retirements on the } \\
\text { association between the change in CEO compensation and the change in R\&D }\end{array}$} \\
\hline \multirow[b]{3}{*}{ Variable } & \multirow{3}{*}{$\begin{array}{l}\text { Pred. } \\
\text { Sign }\end{array}$} & \multicolumn{6}{|c|}{ Dependent Variable } \\
\hline & & \multicolumn{2}{|c|}{$\triangle \ln C \_P A Y(1)$} & \multicolumn{2}{|c|}{$\Delta \ln T_{-} P A Y(2)$} & \multicolumn{2}{|c|}{$\triangle \ln L \_P A Y(3)$} \\
\hline & & Coeff. & P-value & Coeff. & P-value & Coeff. & P-value \\
\hline Intercept & & -0.016 & $(0.08)$ & -0.001 & $(0.97)$ & -0.019 & $(0.78)$ \\
\hline$\triangle R O A$ & + & 1.034 & $(<0.01)$ & 1.574 & $(<0.01)$ & 1.627 & $(0.03)$ \\
\hline$A D J \_R E T$ & + & 0.125 & $(0.01)$ & 0.293 & $(0.02)$ & 0.519 & $(0.14)$ \\
\hline$\Delta R D$ & $?$ & 0.073 & $(0.85)$ & 0.383 & $(0.68)$ & 1.814 & $(0.67)$ \\
\hline HORIZON & $?$ & 0.029 & $(0.25)$ & -0.074 & $(0.16)$ & -0.571 & $(0.07)$ \\
\hline COOPTED_CC & $?$ & 0.004 & $(0.67)$ & 0.007 & $(0.75)$ & 0.006 & $(0.95)$ \\
\hline$H O R I Z O N \times \triangle R O A$ & - & 0.353 & $(0.24)$ & -0.067 & $(0.46)$ & 2.638 & $(0.54)$ \\
\hline$H O R I Z O N \times R E T$ & + & -0.030 & $(0.84)$ & -0.377 & $(0.30)$ & -0.661 & $(0.84)$ \\
\hline$H O R I Z O N \times \triangle R D$ & $?$ & -2.440 & $(0.21)$ & 5.447 & $(0.09)$ & -5.988 & $(0.65)$ \\
\hline $\begin{array}{l}\text { HORIZON } \times \text { COOPTED_ } \\
C C\end{array}$ & $?$ & -0.028 & $(0.39)$ & 0.031 & $(0.64)$ & 0.730 & $(0.08)$ \\
\hline$C O O P T E D \_C C \times \triangle R D$ & $?$ & 0.770 & $(0.10)$ & 0.367 & $(0.79)$ & -1.347 & $(0.79)$ \\
\hline $\begin{array}{l}\text { HORIZON } \times C O O P T E D \\
\text { _CC } \times \triangle R D\end{array}$ & - & 1.314 & $(0.57)$ & -6.880 & $(0.05)$ & -22.84 & $(0.30)$ \\
\hline $\bar{E}$ EQUITY_INCENTIVES & $?$ & 0.000 & $(0.60)$ & & & & \\
\hline No. of observations & & & 380 & & 354 & & \\
\hline $\mathrm{R}^{2}$ & & 17. & $44 \%$ & & $6 \%$ & & $1 \%$ \\
\hline \multicolumn{8}{|c|}{$\begin{array}{l}\text { The table presents OLS regression results for model (5). } \triangle \ln C P A Y \text { is the change in the natural } \\
\text { logarithm of CEO salary and bonus. } \triangle \ln T P A Y \text { is the change in the natural logarithm of CEO } \\
\text { total compensation (EXECUCOMP data item TDC1). } \triangle \ln L P A Y \text { is the change in natural } \\
\text { logarithm of CEO long-term compensation, which is defined as the sum of restricted stock grants, } \\
\text { value of option grants, and long-term incentive payouts. All the compensation measures are } \\
\text { adjusted to } 2003 \text { dollars using Consumer Price Index. } \triangle R O A \text { is the change in earnings before } \\
\text { extraordinary items, scaled by lagged total assets. } A D J R E T \text { is the firm's annual size-adjusted } \\
\text { stock return. } \triangle R D \text { is the change in R\&D expenditures, scaled by lagged total assets. HORIZON is } \\
\text { an indicator variable equal to one if CEOs are in each of the final two years prior to their } \\
\text { retirement, and zero otherwise. COOPTED_CC is an indicator variable equal to one if the } \\
\text { majority of compensation committee directors are appointed after the incumbent CEO assumes } \\
\text { office, and zero otherwise. EQUITY_INCENTIVES is the CEO's dollar wealth increase from a } 1 \% \\
\text { change in stock price, as measured in Core and Guay (2002). The p-values are presented in } \\
\text { parentheses and are two-tailed. The standard errors are heteroskedasticity robust, clustered by } \\
\text { firm and year. For the sake of brevity, we do not report coefficient estimates for year indicators. }\end{array}$} \\
\hline
\end{tabular}




\begin{tabular}{llllllll}
\hline \multicolumn{2}{c}{ TABLE 9 Regression Results: The effect of whether compensation committees are } \\
dominated by co-opted directors and whether CEOs are approaching retirements on the \\
association between the change in CEO compensation and the change in discretionary \\
accruals
\end{tabular}

The table presents regression results for model (6). $\triangle \ln C_{-} P A Y$ is the change in the natural logarithm of CEO salary and bonus. $\triangle \ln T_{-} P A Y$ is the change in the natural logarithm of CEO total compensation. $\triangle \ln L P A Y$ is the change in natural logarithm of CEO long-term compensation. $\triangle R O A$ is the change in earnings before extraordinary items, scaled by lagged total assets. $A D J \_R E T$ is the firm's annual size-adjusted stock return. $P O S \_\triangle D A$ is the positive changes in discretionary accruals. $N E G \_\triangle D A$ is the negative changes in discretionary accruals. $H O R I Z O N$ is an indicator variable equal to one if CEOs are in each of the final two years prior to their retirement, and zero otherwise.COOPTED_CC is an indicator variable equal to one if the majority of compensation committee directors are appointed after the incumbent $\mathrm{CEO}$ assumes office, and zero otherwise. EQUITY_INCENTIVES is the CEO's dollar wealth increase from a 1\% change in stock price, as measured in Core and Guay (2002). The p-values are presented in parentheses and are one-tailed for coefficients that have the predicted sign and two-tailed for those without a predicted sign or those that do not have the predicted sign. The standard errors are heteroskedasticity robust, clustered by firm and year. For the sake of brevity, we do not report coefficient estimates for year indicators. 
TABLE 10 Robustness Tests

Panel A: CEO compensation regressed on the alternative measures of compensation committee co-option

\begin{tabular}{|c|c|c|c|c|c|}
\hline \multicolumn{6}{|c|}{ Dependent Variable $=\ln T \_P A Y$} \\
\hline & & \multicolumn{4}{|c|}{ Compensation committee co-option measures } \\
\hline Variable & & $\begin{array}{c}\text { CC_COOP } \\
\text { TION(1) }\end{array}$ & $\begin{array}{c}T W_{-} C C_{-} C O O \\
P T I O N(2)\end{array}$ & $\begin{array}{c}R E S \_C C \_C O O P \\
\overline{T I O N}(3)\end{array}$ & $\begin{array}{l}R E S \_T W \_C C_{-} \\
C O O P T I O N(4)\end{array}$ \\
\hline \multirow[t]{2}{*}{ Intercept } & & 4.872 & 4.881 & 4.894 & 4.890 \\
\hline & & $(<0.01)$ & $(<0.01)$ & $(<0.01)$ & $(<0.01)$ \\
\hline \multirow[t]{2}{*}{ Co-option measures } & + & 0.128 & 0.124 & 0.128 & 0.124 \\
\hline & & $(<0.01)$ & $(<0.01)$ & $(<0.01)$ & $(<0.01)$ \\
\hline \multirow[t]{2}{*}{ SIZE } & + & 0.374 & 0.374 & 0.374 & 0.374 \\
\hline & & $(<0.01)$ & $(<0.01)$ & $(<0.01)$ & $(<0.01)$ \\
\hline \multirow[t]{2}{*}{$R E T$} & + & 0.106 & 0.106 & 0.106 & 0.106 \\
\hline & & $(<0.01)$ & $(<0.01)$ & $(<0.01)$ & $(<0.01)$ \\
\hline \multirow[t]{2}{*}{$R O A$} & + & 1.134 & 1.136 & 1.134 & 1.136 \\
\hline & & $(<0.01)$ & $(<0.01)$ & $(<0.01)$ & $(<0.01)$ \\
\hline \multirow[t]{2}{*}{ CEO_TENURE } & + & -0.001 & -0.000 & 0.004 & 0.004 \\
\hline & & $(0.71)$ & $(0.83)$ & $(<0.01)$ & $(<0.01)$ \\
\hline \multirow[t]{2}{*}{ CEO_OWNERSHIP } & $?$ & -0.003 & -0.003 & -0.003 & -0.003 \\
\hline & & $(<0.01)$ & $(<0.01)$ & $(<0.01)$ & $(<0.01)$ \\
\hline \multirow[t]{2}{*}{ CEO_CHAIR } & + & 0.127 & 0.128 & 0.127 & 0.128 \\
\hline & & $(<0.01)$ & $(<0.01)$ & $(<0.01)$ & $(<0.01)$ \\
\hline \multirow[t]{2}{*}{ B_INDEPENDENCE } & $?$ & 0.202 & 0.204 & 0.202 & 0.204 \\
\hline & & $(<0.01)$ & $(<0.01)$ & $(<0.01)$ & $(<0.01)$ \\
\hline \multirow[t]{2}{*}{ B_OWNERSHIP } & - & -0.000 & -0.000 & -0.000 & -0.000 \\
\hline & & $(<0.01)$ & $(<0.01)$ & $(<0.01)$ & $(<0.01)$ \\
\hline \multirow[t]{2}{*}{ B_SIZE } & + & 0.002 & 0.003 & 0.002 & 0.003 \\
\hline & & $(0.28)$ & $(0.23)$ & $(0.28)$ & $(0.23)$ \\
\hline \multirow[t]{2}{*}{ B_FEMALE } & $?$ & -0.036 & -0.036 & -0.036 & -0.036 \\
\hline & & $(0.02)$ & $(0.02)$ & $(0.02)$ & $(0.02)$ \\
\hline Observations & & 13,606 & 13,598 & 13,606 & 13,598 \\
\hline $\mathrm{R}^{2}$ & & $40.20 \%$ & $40.18 \%$ & $40.20 \%$ & $40.18 \%$ \\
\hline
\end{tabular}


The table reports regression results for model (2) using alternative measures of compensation committee co-option. InT_PAY is the natural logarithm of CEO total compensation (EXECUCOMP data item TDC1). CC_COOPTION is the proportion of directors who are appointed after the CEO assumes office on the compensation committee. $T W_{-} C C_{-} C O O P T I O N$ is the director tenure weighted co-option, which is the sum of tenure of co-opted Compensation Committee directors divided by the sum of tenure of all compensation committee directors. RES CC COOPTION is the residual from regression of CC COOPTION on CEO tenure. $R E S \_T W \_C C \_C O O P T I O N$ is the residual from the regression of $T W_{-} C C_{-} C O O P T I O N$ on CEO tenure. SIZE is the natural logarithm of sales. RET is the firm's stock return. $R O A$ is the earnings before extraordinary item divided by total assets. CEO_TENURE is the CEO tenure.

CEO_OWNERSHIP is the proportion of the firm's outstanding shares held by CEO.

CEO_CHAIR is an indicator variable equal to one if CEO is the chairman of the board of directors, and zero otherwise. $B$ INDEPENDENCE is the proportion of outsiders on the board of directors. B_OWNERSHIP is the proportion of the firm's outstanding shares held by directors on the board B_SIZE is the number of directors on the board. $B_{-}$FEMALE is an indicator equal to one if at least one of the directors on the board is female, and zero otherwise. The p-values are presented in parentheses and are one-tailed for coefficients that have the predicted sign and twotailed for those without a predicted sign or those that do not have the predicted sign. The standard errors are heteroskedasticity robust, clustered by firm and year. For the sake of brevity, we do not report coefficient estimates for year indicators and $\mathrm{G}$ index dummies. 


\begin{tabular}{|c|c|c|c|c|c|c|c|}
\hline \multirow{2}{*}{\multicolumn{8}{|c|}{$\begin{array}{l}\text { Panel B: The effect of compensation committee dominated by co-opted di } \\
\text { adjusting CEO compensation to mitigate } R \& D \text { reduction after controllin } \\
\text { corporate governance }\end{array}$}} \\
\hline & & & & & & Dependent v ariabie & \\
\hline \multirow{2}{*}{ 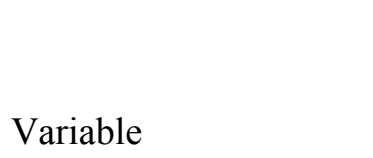 } & \multirow{2}{*}{$\begin{array}{l}\text { Pred. } \\
\text { Sign }\end{array}$} & \multicolumn{2}{|c|}{$\Delta \ln C \_P A Y(1)$} & \multicolumn{2}{|c|}{$\Delta \ln T \_P A Y(2)$} & \multicolumn{2}{|c|}{$\triangle \ln L \_P A Y(3)$} \\
\hline & & Coeff. & P-value & Coeff. & P-value & Coeff. & P-value \\
\hline Intercept & & 0.010 & $(0.80)$ & 0.065 & $(0.41)$ & -0.067 & $(0.93)$ \\
\hline$\triangle R O A$ & + & 1.031 & $(<0.01)$ & 1.572 & $(<0.01)$ & 1.604 & $(0.03)$ \\
\hline$A D J \_R E T$ & + & 0.126 & $(0.01)$ & 0.295 & $(0.02)$ & 0.533 & $(0.13)$ \\
\hline$\Delta R D$ & $?$ & 0.026 & $(0.95)$ & 0.262 & $(0.78)$ & 1.270 & $(0.76)$ \\
\hline HORIZON & $?$ & 0.031 & $(0.22)$ & -0.063 & $(0.22)$ & -0.554 & $(0.08)$ \\
\hline COOPTED_CC & $?$ & 0.003 & $(0.81)$ & 0.029 & $(0.30)$ & -0.019 & $(0.85)$ \\
\hline$H O R I Z O N \times \triangle R O A$ & - & 0.351 & $(0.24)$ & -0.068 & $(0.46)$ & 2.632 & $(0.54)$ \\
\hline$H O R I Z O N \times A D J \_R E T$ & + & -0.037 & $(0.81)$ & -0.384 & $(0.29)$ & -0.745 & $(0.82)$ \\
\hline$H O R I Z O N \times \triangle R D$ & $?$ & -2.365 & $(0.23)$ & 5.490 & $(0.09)$ & -4.531 & $(0.73)$ \\
\hline $\begin{array}{l}\text { HORIZON } \times \text { COOPTE } \\
\text { D_CC }\end{array}$ & $?$ & -0.027 & $(0.40)$ & 0.031 & $(0.64)$ & 0.742 & $(0.07)$ \\
\hline COOPTED_CC $\times \triangle R D$ & $?$ & 0.784 & $(0.10)$ & 0.459 & $(0.74)$ & -1.148 & $(0.82)$ \\
\hline $\begin{array}{l}\text { HORIZON } \times C O O P T E \\
D \_C C \times \triangle R D\end{array}$ & - & 1.275 & $(0.59)$ & -6.717 & $(0.05)$ & -24.179 & $(0.28)$ \\
\hline InCEO_TENURE & $?$ & -0.000 & $(0.99)$ & -0.033 & $(0.09)$ & 0.009 & $(0.92)$ \\
\hline CEO_CHAIR & $?$ & -0.007 & $(0.48)$ & -0.024 & $(0.41)$ & -0.045 & $(0.66)$ \\
\hline B_INDDIR & $?$ & 0.025 & $(0.62)$ & 0.075 & $(0.49)$ & 0.683 & $(0.44)$ \\
\hline $\ln B \_S I Z E$ & $?$ & -0.022 & $(0.20)$ & -0.034 & $(0.41)$ & -0.283 & $(0.17)$ \\
\hline $\begin{array}{l}\text { EQUITY_INCENTIVE } \\
S\end{array}$ & $?$ & 0.000 & $(0.48)$ & & & & \\
\hline No. of observations & & & 80 & & 54 & & \\
\hline $\mathrm{R}^{2}$ & & & $9 \%$ & & $4 \%$ & & \\
\hline
\end{tabular}


The table reports regression results for model (5) after controlling for other corporate governance. $\triangle \ln C_{-} P A Y$ is the change in the natural logarithm of CEO salary and bonus. $\triangle \ln T_{-} P A Y$ is the change in the natural logarithm of CEO total compensation (EXECUCOMP data item TDC1). $\triangle \ln L \_P A Y$ is the change in natural logarithm of CEO long-term compensation, which is defined as the sum of restricted stock grants, value of option grants, and long-term incentive payouts. All the compensation measures are adjusted to 2003 dollars using Consumer Price Index. $\triangle R O A$ is the change in earnings before extraordinary items, scaled by lagged total assets. $A D J R E T$ is the firm's annual size-adjusted stock return. $\triangle R D$ is the change in $\mathrm{R} \& \mathrm{D}$ expenditures, scaled by lagged total assets. HORIZON is an indicator variable equal to one if CEOs are in each of the final two years prior to their retirement, and zero otherwise. COOPTED_CC is an indicator variable equal to one if the majority of compensation committee directors are appointed after the incumbent $\mathrm{CEO}$ assumes office, and zero otherwise. InCEO_TENURE is the natural logarithm of CEO tenure. CEO_CHAIR is an indicator variable equal to one if CEO is the chairman of the board of directors, and zero otherwise. $B_{-} I N D D I R$ is an indicator variable equal to one if the board of directors solely consists of outsiders, and zero otherwise. $\ln B \_S I Z E$ is the natural logarithm of number of directors on the board. EQUITY_INCENTIVES $\bar{S}$ is the CEO's dollar wealth increase from a $1 \%$ change in stock price, as measured in Core and Guay (2002). The p-values are presented in parentheses and are one-tailed for coefficients that have the predicted sign and two-tailed for those without a predicted sign or those that do not have the predicted sign. The standard errors are heteroskedasticity robust, clustered by firm and year. For the sake of brevity, we do not report coefficient estimates for year indicators. 


\begin{tabular}{|c|c|c|c|c|c|c|c|}
\hline \multicolumn{8}{|c|}{$\begin{array}{l}\text { Panel C: The effect of compensation committee dominated by co-opted directors on } \\
\text { adjusting CEO compensation to mitigate income-increasing accruals management after } \\
\text { controlling for other corporate governance }\end{array}$} \\
\hline \multirow[b]{3}{*}{ Variable } & & \multicolumn{6}{|c|}{ Dependent Variable } \\
\hline & & \multicolumn{2}{|c|}{$\triangle \ln C \_P A Y(1)$} & \multicolumn{2}{|c|}{$\Delta \ln T_{-} P A Y(2)$} & \multicolumn{2}{|c|}{$\Delta \operatorname{lnL} P A Y(3)$} \\
\hline & & Coeff. & $\mathrm{P}$-value & Coeff. & $\mathrm{P}$-value & Coeff. & P-value \\
\hline Intercept & & 0.031 & $(0.33)$ & 0.064 & $(0.32)$ & -0.252 & $(0.64)$ \\
\hline$\triangle R O A$ & + & 1.012 & $(<0.01)$ & 1.620 & $(<0.01)$ & 1.879 & $(<0.01)$ \\
\hline$A D J \_R E T$ & + & 0.184 & $(<0.01)$ & 0.330 & $(<0.01)$ & 0.939 & $(0.02)$ \\
\hline$P O S \_\triangle D A$ & $?$ & -0.000 & $(0.96)$ & -0.019 & $(0.18)$ & 0.054 & $(0.66)$ \\
\hline$N E G \_\Delta D A$ & $?$ & 0.015 & $(0.01)$ & -0.005 & $(0.73)$ & -0.014 & $(0.78)$ \\
\hline HORIZON & $?$ & 0.046 & $(0.04)$ & -0.027 & $(0.52)$ & -0.271 & $(0.04)$ \\
\hline COOPTED_CC & $?$ & 0.009 & $(0.29)$ & 0.030 & $(0.14)$ & 0.056 & $(0.54)$ \\
\hline$H O R I Z O N \times \triangle R O A$ & - & 0.045 & $(0.86)$ & -0.165 & $(0.37)$ & 2.273 & $(0.46)$ \\
\hline$H O R I Z O N \times R E T$ & + & -0.030 & $(0.81)$ & -0.258 & $(0.34)$ & -0.472 & $(0.83)$ \\
\hline$H O R I Z O N \times P O S \_\triangle D A$ & $?$ & -0.002 & $(0.89)$ & -0.050 & $(0.23)$ & -0.837 & $(0.23)$ \\
\hline$H O R I Z O N \times N E G \_\Delta D A$ & $?$ & 0.016 & $(0.51)$ & 0.028 & $(0.40)$ & -0.069 & $(0.55)$ \\
\hline $\begin{array}{l}\text { HORIZON } \times C O O P T E D \\
\text { CC }\end{array}$ & $?$ & -0.065 & $(0.02)$ & -0.002 & $(0.97)$ & 0.276 & $(0.23)$ \\
\hline $\begin{array}{l}\bar{C} O O P T E D \_C C \times P O S_{-} \\
\triangle D A\end{array}$ & $?$ & -0.005 & $(0.48)$ & -0.001 & $(0.96)$ & -0.080 & $(0.53)$ \\
\hline $\begin{array}{l}\text { COOPTED_CC } \times N E G_{-} \\
\triangle D A\end{array}$ & $?$ & -0.016 & $(0.02)$ & 0.005 & $(0.77)$ & 0.015 & $(0.84)$ \\
\hline $\begin{array}{l}\text { HORIZON } \times C O O P T E \\
D \_C C \times P O S \_\triangle D A\end{array}$ & + & 0.034 & $(0.08)$ & 0.042 & $(0.23)$ & 0.885 & $(0.11)$ \\
\hline $\begin{array}{l}\text { HORIZON } \times \overline{C O O P T E D} \\
\_C C \times N E G \_\triangle D A\end{array}$ & $?$ & -0.017 & $(0.54)$ & -0.017 & $(0.71)$ & 0.156 & $(0.35)$ \\
\hline InCEO_TENURE & $?$ & 0.000 & $(0.71)$ & -0.035 & $(0.01)$ & -0.060 & $(0.41)$ \\
\hline CEO_CHAIR & $?$ & -0.006 & $(0.35)$ & -0.014 & $(0.48)$ & -0.013 & $(0.85)$ \\
\hline B_INDDIR & $?$ & -0.006 & $(0.44)$ & 0.101 & $(0.23)$ & 1.034 & $(0.10)$ \\
\hline $\ln B \_S I Z E$ & $?$ & 0.040 & $(0.31)$ & -0.036 & $(0.23)$ & -0.288 & $(0.05)$ \\
\hline EQUITY_INCENTIVES & $?$ & -0.031 & $(0.02)$ & & & & \\
\hline No. of observations & & & & & & & 63 \\
\hline $\mathrm{R}^{2}$ & & & $6 \%$ & & $7 \%$ & & $5 \%$ \\
\hline
\end{tabular}


The table presents OLS regression results for equation (6) after controlling for other corporate governance. $\triangle \ln C_{-} P A Y$ is the change in the natural logarithm of $\mathrm{CEO}$ salary and bonus. $\triangle \ln T \_P A Y$ is the change in the natural logarithm of CEO total compensation (EXECUCOMP data item TDC1). $\triangle \ln L \_P A Y$ is the change in natural logarithm of CEO long-term compensation, which is defined as the sum of restricted stock grants, value of option grants, and long-term incentive payouts. All the compensation measures are adjusted to 2003 dollars using Consumer Price Index. $\triangle R O A$ is the change in earnings before extraordinary items, scaled by lagged total assets. $A D J R E T$ is the firm's annual size-adjusted stock return. $P O S \_\triangle D A$ is the positive changes in discretionary accruals. $N E G \_\triangle D A$ is the negative changes in discretionary accruals. $H O R I Z O N$ is an indicator variable equal to one if CEOs are in each of the final two years prior to their retirement, and zero otherwise.COOPTED_CC is an indicator variable equal to one if the majority of compensation committee directors are appointed after the incumbent CEO assumes office, and zero otherwise. InCEO_TENURE is the natural logarithm of CEO tenure.

CEO_CHAIR is an indicator variable equal to one if CEO is the chairman of the board of directors, and zero otherwise. $B_{-} I N D D I R$ is an indicator variable equal to one if the board of directors solely consists of outsiders, and zero otherwise. $\ln B \_S I Z E$ is the natural logarithm of a number of directors on the board. EQUITY INCENTIVES is the CEO's dollar wealth increase from a $1 \%$ change in stock price, as measured in Core and Guay (2002). The p-values are presented in parentheses and are one-tailed for coefficients that have the predicted sign and twotailed for those without a predicted sign or those that do not have the predicted sign. The standard errors are heteroskedasticity robust, clustered by firm and year. For the sake of brevity, we do not report coefficient estimates for year indicators. 
Panel D: The effect of compensation committee dominated by co-opted directors on CEO compensation for the subsample of 2004-2011

\begin{tabular}{lccc}
\hline \multicolumn{4}{c}{ Dependent Variable $=\ln T$ PAY } \\
\hline Variable & Predicted Sign & Coefficient & p-value \\
\hline Intercept & & 4.696 & $(<0.01)$ \\
COOPTED_CC & + & 0.067 & $(<0.01)$ \\
SIZE & + & 0.373 & $(<0.01)$ \\
RET & + & 0.146 & $(<0.01)$ \\
ROA & + & 0.998 & $(<0.01)$ \\
CEO_TENURE & + & 0.001 & $(0.41)$ \\
CEO_OWNERSHIP & $?$ & -0.003 & $(<0.01)$ \\
CEO_CHAIR & + & 0.112 & $(<0.01)$ \\
B_INDEPENDENCE & $?$ & 0.515 & $(<0.01)$ \\
B_OWNERSHIP & - & 0.000 & $(<0.01)$ \\
B_SIZE & + & 0.012 & $(0.01)$ \\
B_FEMALE & $?$ & -0.009 & $(0.65)$ \\
Observations & & & 6,618 \\
$\mathrm{R}^{2}$ & & & $46.26 \%$ \\
\hline
\end{tabular}

This table presents regression results of model (2) for the subsample of 2004-2011. $\ln T$ PAY is the natural logarithm of CEO total compensation (EXECUCOMP data item TDC1). It is adjusted to 2003 dollars using Consumer Price Index. COOPTED_CC is an indicator variable equal to one if the majority of compensation committee directors are appointed after the incumbent CEO assumes office, and zero otherwise. SIZE is the natural logarithm of sales. RET is the firm's stock return. $R O A$ is the earnings before extraordinary item divided by total assets. CEO_TENURE is the CEO tenure. CEO_OWNERSHIP is the proportion of the firm's outstanding shares held by CEO.CEO_CHAIR is an indicator variable equal to one if CEO is the chairman of the board of directors, and zero otherwise. B_INDEPENDENCE is the proportion of outsiders on the board of directors. $B$ _OWNERSHIP is the proportion of the firm's outstanding shares held by directors on the board. $B \_S I Z E$ is the number of directors on the board. B_FEMALE is an indicator equal to one if at least one of the directors on the board is female, and zero otherwise. The p-values are presented in parentheses and are one-tailed for coefficients that have the predicted sign and two-tailed for those without a predicted sign or those that do not have the predicted sign. The standard errors are heteroskedasticity robust, clustered by firm and year. For the sake of brevity, we do not report coefficient estimates for year indicators and $\mathrm{G}$ index dummies. 


\begin{tabular}{|c|c|c|c|}
\hline \multicolumn{4}{|c|}{$\begin{array}{l}\text { Panel E: The effect of whether compensation committees are dominated by co-opted } \\
\text { directors on the association between R\&D spending and CEO horizon problem for the } \\
\text { subsample of 2004-2011 }\end{array}$} \\
\hline \multicolumn{4}{|c|}{ Dependent Variable $=R D$} \\
\hline Variable & Predicted Sign & Coefficient & P-value \\
\hline Intercept & & 0.034 & $(<0.01)$ \\
\hline HORIZON & $?$ & 0.003 & $(0.39)$ \\
\hline COOPTED_CC & $?$ & 0.004 & $(<0.01)$ \\
\hline HORIZON $\times$ COOPTED_CC & - & -0.004 & $(0.19)$ \\
\hline TOBINS_Q & + & 0.002 & $(0.07)$ \\
\hline$L A G \_R E T$ & + & -0.004 & $(0.03)$ \\
\hline$F C F$ & + & -0.213 & $(<0.01)$ \\
\hline$R O A$ & - & 0.237 & $(<0.01)$ \\
\hline SIZE & $?$ & -0.001 & $(0.27)$ \\
\hline FIRM_AGE & - & 0.000 & $(<0.01)$ \\
\hline EQUITY_INCENTIVES & + & 0.000 & $(0.15)$ \\
\hline INDUSTRY_RD & + & \multicolumn{2}{|r|}{$(<0.01)$} \\
\hline Number of observations & & \multicolumn{2}{|c|}{3,580} \\
\hline $\mathrm{R}^{2}$ & & \multicolumn{2}{|c|}{$49.40 \%$} \\
\hline \multicolumn{4}{|c|}{$\begin{array}{l}\text { The table presents OLS regressions results of model (3) for the subsample of 2004-2011. } \\
R D \text { is the R\&D expense scaled by total assets. COOPTED_CC is an indicator variable } \\
\text { equal to one if the majority of compensation committee directors are appointed after the } \\
\text { incumbent CEO assumes, and zero otherwise. } H O R I Z O N \text { is an indicator variable equal } \\
\text { to one if CEOs are in each of the final two years prior to their retirement, and zero } \\
\text { otherwise. TOBINS_Q is calculated as the market value of equity plus the book value of } \\
\text { debt, all scaled by total assets. } L A G \_R E T \text { is the stock return from previous year. } F C F \text { is } \\
\text { the operating cash flows plus R\&D expense minus capital expenditures, all scaled by } \\
\text { sales. } R O A \text { is operating net income before R\&D expense scaled by assets. SIZE is the } \\
\text { natural logarithm of total assets at the beginning of the current year. FIRM_AGE is the } \\
\text { number of years between the current year and the first year the company listed on } \\
\text { Compustat. EQUITY_INCENTIVES is the CEO's dollar wealth increase from a } 1 \% \\
\text { change in stock price, as measured in Core and Guay (2002). INDUSTRY_RD is the } \\
\text { average R\&D expenditures of other firms in the same 2-digit SIC industry. The p-values } \\
\text { are presented in parentheses and are one-tailed for coefficients that have the predicted } \\
\text { sign and two-tailed for those without a predicted sign or those that do not have the } \\
\text { predicted sign. The standard errors are heteroskedasticity robust, clustered by firm and } \\
\text { year. For the sake of brevity, we do not report coefficient estimates for year indicators. }\end{array}$} \\
\hline
\end{tabular}




\begin{tabular}{|c|c|c|c|}
\hline \multicolumn{4}{|c|}{$\begin{array}{l}\text { Panel F: The effect of whether compensation committees are dominated by co-opted } \\
\text { directors on the association between discretionary accruals and CEO horizon problem for } \\
\text { the subsample of 2004-2011 }\end{array}$} \\
\hline \multicolumn{4}{|c|}{ Dependent Variable $=D A$} \\
\hline Variable & Predicted Sign & Coefficient & P-value \\
\hline Intercept & & 0.029 & $(0.85)$ \\
\hline HORIZON & + & -0.066 & $(0.42)$ \\
\hline COOPTED_CC & $?$ & -0.059 & $(0.04)$ \\
\hline HORIZON $\times$ COOPTED_CC & + & 0.165 & $(0.05)$ \\
\hline EQUITY_INCENTIVES & + & 0.035 & $(0.31)$ \\
\hline$S I Z E$ & - & -0.005 & $(0.34)$ \\
\hline STD_CASHFLOW & $?$ & -0.755 & $(0.27)$ \\
\hline$S T D \_R E V$ & $?$ & 0.209 & $(0.21)$ \\
\hline STD_SALESGROWTH & $?$ & 0.221 & $(0.05)$ \\
\hline OLDFIRM & $?$ & 0.036 & $(0.25)$ \\
\hline LEVERAGE & $?$ & -0.007 & $(0.95)$ \\
\hline MARKETTOBOOK & $?$ & -0.004 & $(0.55)$ \\
\hline Number of observations & & \multicolumn{2}{|c|}{5,248} \\
\hline $\mathrm{R}^{2}$ & & \multicolumn{2}{|c|}{$5.34 \%$} \\
\hline
\end{tabular}

The table presents OLS regressions results of model (4) for the subsample of 2004-2011. DA is the discretionary accruals. COOPTED_CC is an indicator variable equal to one if the majority of compensation committee directors are appointed after the incumbent CEO assumes office, and zero otherwise. HORIZON is an indicator variable equal to one if CEOs are in each of the final two years prior to their retirement, and zero otherwise. EQUITY INCENTIVES is the dollar change in CEO's wealth from a 1\% change in stock price, as measured in Core and Guay (2002), then normalized by the sum of the dollar change, salary and bonus. SIZE is the natural logarithm of total assets at the beginning of the current year. STD_CASHFLOW is the standard deviation of cash flows from operations deflated by total assets over the current and previous four years. $S T D \_R E V$ is the standard deviation of sales deflated by total assets over the current and previous four years. STD_SALESGROWTH is the standard deviation of sales growth over the current and previous four years. OLDFIRM equals one if a firm is listed on Compustat for more than 20 years, and zero otherwise. LEVERAGE is total liabilities deflated by total assets.

MARKETTOBOOK represents deciles of market value of assets divided by the book value of assets ranked within each year. The p-values are presented in parentheses and are one-tailed for coefficients that have the predicted sign and two-tailed for those without a predicted sign or those that do not have the predicted sign. The standard errors are heteroskedasticity robust, clustered by firm and year. For the sake of brevity, we do not report coefficient estimates for year indicators, G_index indicators, exchange indicators and industry indicators. 
Panel G Regression Results: The effect of compensation committee dominated by coopted directors on adjusting $C E O$ compensation to mitigate $R \& D$ reduction for the subsample of 2004-2011

\begin{tabular}{|c|c|c|c|c|c|c|c|}
\hline \multirow[b]{3}{*}{ Variable } & \multirow{3}{*}{$\begin{array}{c}\text { Pred. } \\
\text { Sign }\end{array}$} & \multicolumn{6}{|c|}{ Dependent Variable } \\
\hline & & \multicolumn{2}{|c|}{$\triangle \ln C \_P A Y(1)$} & \multicolumn{2}{|c|}{$\triangle \ln T_{-} P A Y(2)$} & \multicolumn{2}{|c|}{$\triangle \operatorname{lnL} P A Y(3)$} \\
\hline & & Coeff. & P-value & Coeff. & P-value & Coeff. & P-value \\
\hline Intercept & & -0.015 & $(0.11)$ & -0.014 & $(0.57)$ & -0.037 & $(0.57)$ \\
\hline$\triangle R O A$ & + & 0.521 & $(<0.01)$ & 1.642 & $(<0.01)$ & 1.536 & $(0.05)$ \\
\hline$A D J \_R E T$ & + & 0.043 & $(0.23)$ & 0.056 & $(0.39)$ & 0.534 & $(0.14)$ \\
\hline$\Delta R D$ & $?$ & 0.013 & $(0.98)$ & 1.501 & $(0.20)$ & 7.097 & $(0.23)$ \\
\hline HORIZON & $?$ & 0.051 & $(0.14)$ & -0.076 & $(0.25)$ & -0.708 & $(0.18)$ \\
\hline COOPTED_CC & $?$ & 0.017 & $(0.10)$ & 0.012 & $(0.64)$ & 0.028 & $(0.76)$ \\
\hline$H O R I Z O N \times \triangle R O A$ & - & 0.171 & $(0.62)$ & -0.468 & $(0.23)$ & 4.580 & $(0.52)$ \\
\hline$H O R I Z O N \times R E T$ & + & 0.205 & $(0.19)$ & 0.199 & $(0.33)$ & -6.871 & $(0.12)$ \\
\hline$H O R I Z O N \times \triangle R D$ & $?$ & -4.445 & $(0.09)$ & -1.867 & $(0.73)$ & -71.730 & $(0.17)$ \\
\hline $\begin{array}{l}H O R I Z O N \times C O O P \\
T E D \_C C\end{array}$ & $?$ & -0.047 & $(0.28)$ & 0.005 & $(0.95)$ & 0.797 & $(0.20)$ \\
\hline $\begin{array}{l}C O O P T E D \_C C \times \Delta \\
R D\end{array}$ & $?$ & 0.309 & $(0.62)$ & 0.553 & $(0.71)$ & -7.901 & $(0.22)$ \\
\hline $\begin{array}{l}\text { HORIZON } \times C O O P \\
T E D \_C C \times \triangle R D\end{array}$ & - & 3.954 & $(0.19)$ & 0.162 & $(0.98)$ & 23.745 & $(0.78)$ \\
\hline $\begin{array}{l}\text { EQUITTY_INCENTI } \\
\text { VES }\end{array}$ & $?$ & 0.000 & $(0.57)$ & & & & \\
\hline No. of observations & & \multicolumn{2}{|c|}{3,450} & \multicolumn{2}{|c|}{3,435} & \multicolumn{2}{|c|}{3,409} \\
\hline $\mathrm{R}^{2}$ & & \multicolumn{2}{|c|}{$20.59 \%$} & \multicolumn{2}{|c|}{$2.66 \%$} & \multicolumn{2}{|c|}{$1.80 \%$} \\
\hline
\end{tabular}

The table presents OLS regressions results of equation (5) for the subsample of 2004-2011. $\triangle \ln C_{-} P A Y$ is the change in the natural logarithm of CEO salary and bonus. $\triangle \ln T+P A Y$ is the change in the natural logarithm of CEO total compensation (EXECUCOMP data item TDC1). $\triangle \ln L \_P A Y$ is the change in natural logarithm of CEO long-term compensation, which is defined as the sum of restricted stock grants, value of option grants, and long-term incentive payouts. All the compensation measures are adjusted to 2003 dollars using Consumer Price Index. $\triangle R O A$ is the change in earnings before extraordinary items, scaled by lagged total assets. $A D J$ RET is the firm's annual size-adjusted stock return. $\triangle R D$ is the change in R\&D expenditures, scaled by lagged total assets. HORIZON is an indicator variable equal to one if CEOs are in each of the final two years prior to their retirement, and zero otherwise. COOPTED_CC is an indicator variable equal to one if the majority of compensation committee directors are appointed after the incumbent CEO assumes office, and zero otherwise. EQUITY_INCENTIVES is the CEO's dollar wealth increase from a 1\% change in stock price, as measured in Core and Guay (2002). The p-values are presented in parentheses and are two-tailed. The standard errors are heteroskedasticity robust, clustered by firm and year. For the sake of brevity, we do not report coefficient estimates for year indicators. 


\begin{tabular}{|c|c|c|c|c|c|c|c|}
\hline \multirow{4}{*}{\multicolumn{2}{|c|}{$\begin{array}{l}\text { Panel H: The effect of co } \\
\text { adjusting CEO compensatio } \\
\\
\text { Variable } \quad \text { Pred. Sign } \\
\end{array}$}} & $\begin{array}{r}\text { pensati } \\
\text { to miti } \\
\text { subs }\end{array}$ & $\begin{array}{l}\text { n commi } \\
\text { ate incom } \\
\text { mple of } 2\end{array}$ & $\begin{array}{l}\text { domina } \\
\text { creasin } \\
-2011\end{array}$ & $\begin{array}{l}\text { I by co-o } \\
\text { ccruals }\end{array}$ & $\begin{array}{l}\text { directo } \\
\text { agement }\end{array}$ & $\begin{array}{l}\text { on } \\
\text { for the }\end{array}$ \\
\hline & & \multicolumn{6}{|c|}{ Dependent Variable } \\
\hline & & \multicolumn{2}{|c|}{$\triangle \ln C \_P A Y(1)$} & \multicolumn{2}{|c|}{$\triangle \ln T P A Y(2)$} & \multicolumn{2}{|c|}{$\Delta \ln L \_P A Y(3)$} \\
\hline & & Coeff. & P-value & Coeff. & P-value & Coeff. & P-value \\
\hline \multicolumn{2}{|l|}{ Intercept } & -0.011 & $(0.18)$ & 0.017 & $(0.40)$ & 0.028 & $(0.70)$ \\
\hline \multicolumn{2}{|l|}{$\triangle R O A$} & 0.563 & $(<0.01)$ & 1.495 & $(<0.01)$ & 1.962 & $(<0.01)$ \\
\hline \multicolumn{2}{|l|}{$A D J \_R E T$} & 0.073 & $(0.06)$ & 0.173 & $(0.12)$ & 1.006 & $(0.02)$ \\
\hline \multicolumn{2}{|l|}{$P O S \_\triangle D A$} & 0.002 & $(0.73)$ & -0.024 & $(0.11)$ & 0.058 & $(0.67)$ \\
\hline \multicolumn{2}{|l|}{$N E G_{-} \Delta D A$} & 0.015 & $(0.01)$ & -0.006 & $(0.64)$ & -0.076 & $(0.11)$ \\
\hline \multicolumn{2}{|l|}{ HORIZON } & 0.071 & $(0.04)$ & -0.054 & $(0.30)$ & -0.334 & $(0.06)$ \\
\hline \multicolumn{2}{|l|}{ COOPTED_CC } & 0.019 & $(0.03)$ & 0.019 & $(0.31)$ & 0.036 & $(0.65)$ \\
\hline \multicolumn{2}{|l|}{$H O R I Z O N \times \triangle R$} & -0.180 & $(0.27)$ & -0.479 & $(0.19)$ & 2.150 & $(0.65)$ \\
\hline \multicolumn{2}{|l|}{$H O R I Z O N \times R E T$} & 0.252 & $(0.12)$ & 0.090 & $(0.40)$ & -4.157 & $(0.09)$ \\
\hline $\begin{array}{l}\text { HORIZON } \times \text { POS } \\
\triangle D A\end{array}$ & $?$ & -0.009 & $(0.59)$ & -0.051 & $(0.23)$ & -0.886 & $(0.24)$ \\
\hline $\begin{array}{l}\bar{H} O R I Z O N \times N E \\
G \_\Delta D A\end{array}$ & $?$ & 0.011 & $(0.71)$ & 0.025 & $(0.49)$ & 0.016 & $(0.90)$ \\
\hline $\begin{array}{l}\text { HORIZON } \times C O \\
\text { OPTED_CC }\end{array}$ & $?$ & -0.111 & $(0.01)$ & -0.029 & $(0.64)$ & 0.177 & $(0.58)$ \\
\hline $\begin{array}{l}C O O P T E D \_C C \\
\times P O S \_\Delta D \bar{A}\end{array}$ & $?$ & -0.009 & $(0.22)$ & 0.002 & $(0.92)$ & -0.069 & $(0.63)$ \\
\hline $\begin{array}{l}C O O P T E D \_C C \\
\times N E G \_\triangle D \bar{A}\end{array}$ & $?$ & -0.016 & $(0.03)$ & 0.013 & $(0.46)$ & 0.076 & $(0.28)$ \\
\hline \multicolumn{8}{|l|}{ HORIZZON $\times C O$} \\
\hline & + & 0.043 & $(0.04)$ & 0.029 & $(0.30)$ & 0.861 & $(0.12)$ \\
\hline \multicolumn{2}{|l|}{$\begin{array}{l}\text { OPTED_CC } \times N \\
E G \_D D A\end{array}$} & -0.027 & $(0.40)$ & -0.028 & $(0.59)$ & 0.058 & $(0.77)$ \\
\hline $\begin{array}{l}\text { EQUUITY_INCE } \\
\text { NTIVES }\end{array}$ & $?$ & 0.000 & $(0.41)$ & & & & \\
\hline \multicolumn{2}{|l|}{$\begin{array}{l}\text { No. of } \\
\text { observations }\end{array}$} & \multicolumn{2}{|c|}{5,614} & \multicolumn{2}{|c|}{5,579} & \multicolumn{2}{|c|}{5,524} \\
\hline \multicolumn{2}{|l|}{$\mathrm{R}^{2}$} & \multicolumn{2}{|c|}{$21.05 \%$} & \multicolumn{2}{|c|}{$2.78 \%$} & & $4 \%$ \\
\hline
\end{tabular}

The table presents OLS regression results of model (6) for the sample of 2004-2011. $\triangle \ln C$ PAY is the change in the natural logarithm of CEO salary and bonus. $\triangle \ln T+P A Y$ is the change in the natural logarithm of CEO total compensation (EXECUCOMP data item TDC1). $\triangle \ln L \_P A Y$ is the change in natural logarithm of CEO long-term compensation, which is defined as the sum of restricted stock grants, value of option grants, and long-term incentive payouts. All the compensation measures are adjusted to 2003 dollars using Consumer Price Index. $\triangle R O A$ is the change in earnings before extraordinary items, scaled by lagged total assets. $A D J R E T$ is the firm's annual size-adjusted stock return. $P O S \_\triangle D A$ is the positive changes in discretionary accruals. $N E G \_\triangle D A$ is the negative changes in discretionary accruals. HORIZON is an indicator variable equal to one if CEOs are in each of the final two years prior to their retirement, and zero 
otherwise. COOPTED_CC is an indicator variable equal to one if the majority of compensation committee directors are appointed after the incumbent $\mathrm{CEO}$ assumes office, and zero otherwise. EQUITY_INCENTIVES is the CEO's dollar wealth increase from a $1 \%$ change in stock price, as measured in Core and Guay (2002). The p-values are presented in parentheses and are one-tailed for coefficients that have the predicted sign and two-tailed for those without a predicted sign or those that do not have the predicted sign. The standard errors are heteroskedasticity robust, clustered by firm and year. For the sake of brevity, we do not report coefficient estimates for year indicators. 


\begin{tabular}{|c|c|c|c|c|c|c|c|c|c|c|c|c|c|c|c|}
\hline & 1 & 2 & 3 & 4 & 5 & 6 & 7 & 8 & 9 & 10 & 11 & 12 & 13 & 14 & 15 \\
\hline 1.B_INDEPENDENCE & 1 & & & & & & & & & & & & & & \\
\hline 2.CC_INDEPENDENCE & 0.57 & & & & & & & & & & & & & & \\
\hline 3.B_COOPTION & -0.01 & -0.01 & & & & & & & & & & & & & \\
\hline 4.CC_COOPTION & -0.03 & 0.02 & 0.91 & & & & & & & & & & & & \\
\hline 5.B_LONGSERV & -0.03 & 0.00 & 0.00 & 0.01 & & & & & & & & & & & \\
\hline 6.CC_LONGSERV & -0.02 & -0.01 & -0.03 & -0.06 & 0.69 & & & & & & & & & & \\
\hline 7.B_SIZE & 0.01 & 0.00 & 0.02 & 0.01 & -0.00 & 0.00 & & & & & & & & & \\
\hline 8.CC_SIZE & 0.03 & 0.00 & 0.02 & 0.02 & 0.00 & -0.00 & 0.99 & & & & & & & & \\
\hline 9.B_OWNERSHIP & -0.24 & -0.14 & 0.04 & 0.05 & 0.01 & 0.01 & -0.01 & -0.02 & & & & & & & \\
\hline 10.CC_OWNERSHIP & -0.13 & -0.21 & -0.00 & -0.02 & 0.01 & 0.02 & -0.01 & 0.00 & 0.66 & & & & & & \\
\hline 11.B_BUSY & 0.12 & 0.02 & -0.09 & -0.09 & -0.02 & -0.01 & 0.02 & 0.02 & -0.05 & -0.02 & & & & & \\
\hline 12.CC_BUSY & 0.07 & 0.03 & -0.07 & -0.07 & -0.02 & -0.00 & 0.02 & 0.02 & -0.03 & -0.03 & 0.79 & & & & \\
\hline 13.CEO_CHAIR & 0.01 & -0.03 & 0.19 & 0.17 & -0.02 & -0.02 & 0.05 & 0.03 & 0.01 & -0.02 & 0.10 & 0.08 & & & \\
\hline 14.IND_NORM & 0.51 & 0.42 & -0.01 & 0.00 & -0.02 & -0.02 & -0.01 & -0.01 & -0.14 & -0.10 & 0.01 & -0.00 & -0.04 & & \\
\hline 15.COOPTED_CC & -0.02 & 0.02 & 0.80 & 0.90 & 0.01 & -0.05 & 0.01 & 0.01 & 0.04 & -0.02 & -0.08 & -0.06 & 0.15 & -0.00 & \\
\hline 16.COOPTED_B & -0.01 & -0.01 & 0.87 & 0.81 & 0.00 & -0.03 & 0.01 & 0.01 & 0.03 & -0.01 & -0.07 & -0.06 & 0.18 & -0.02 & 0.77 \\
\hline
\end{tabular}


This panel displays the Pearson correlations between the board and compensation committee characteristics variables. Correlations significant at the 5\% level or less appear in bold. CC_COOPTION is the proportion of directors who are appointed after the CEO assumes office on the compensation committee. $B$ _COOPTION is the proportion of directors who are appointed after the CEO assumes office on the board of directors. COOPTED_CC is an indicator variable equal to one if the majority of compensation committee directors are appointed after the incumbent CEO assumes office, and zero otherwise. COOPTED_B is an indicator variable equal to one if the majority of directors on the board are appointed after the incumbent $\mathrm{CEO}$ assumes office, and zero otherwise. CEO_CHAIR is an indicator variable equal to one if CEO is the chairman of the board of directors, and zero otherwise. B_INDEPENDENCE is the proportion of outsiders on the board of directors. CC_INDEPENDENCE is the proportion of outsiders on the compensation committee. IND_NORM is an indicator variable equal to one if the firm has a nominating committee that consists of only outside directors. CC_SIZE is the number of directors on the compensation committee. $B \_S I Z E$ is the number of directors on the board of directors. $B \_B U S Y$ is the proportion of board directors who sit on more than three other boards of public companies. $C C_{-} B U S Y$ is the proportion of compensation committee directors who sit on more than three other boards of public companies. B_LONGSERV is the average tenure of directors on the board. CC_LONGSERV is the average tenure of directors on the compensation committee. CC_OWNERSHIP is the total shares held by directors on the compensation committee divided by total outstanding shares. $B \_O W N E R S H I P$ is the total shares held by directors on the board divided by total outstanding shares. $B \_S I Z E$ is the number of directors on the board. 


\begin{tabular}{|c|c|c|c|}
\hline \multicolumn{4}{|c|}{ TABLE 12 Factors Identified in Principal Components Analysis } \\
\hline Factor & Factor Name & $\begin{array}{l}\text { Board and Compensation Committee } \\
\text { characteristics }\end{array}$ & $\begin{array}{l}\text { Factor } \\
\text { Loadings }\end{array}$ \\
\hline \multirow[t]{5}{*}{1} & CEO_POWER & CC_COOPTION & 0.959 \\
\hline & & B_COOPTION & 0.951 \\
\hline & & COOPTED_CC & 0.919 \\
\hline & & COOPTED_B & 0.916 \\
\hline & & CEO_CHAIR & 0.269 \\
\hline \multirow[t]{3}{*}{2} & INDEPENDENCE & B_INDEPENDENCE & 0.848 \\
\hline & & CC_INDEPENDENCE & 0.794 \\
\hline & & IND_NORM & 0.793 \\
\hline \multirow[t]{2}{*}{3} & DIR_SIZE & CC_SIZE & 0.996 \\
\hline & & B_SIZE & 0.996 \\
\hline \multirow[t]{2}{*}{4} & BUSY_DIR & $B \_B U S Y$ & 0.936 \\
\hline & & $C C_{-} B U S Y$ & 0.93 \\
\hline \multirow[t]{2}{*}{5} & DIR_TENURE & B_LONGSERV & 0.919 \\
\hline & & CC_LONGSERV & 0.918 \\
\hline \multirow[t]{2}{*}{6} & DIR_OWNERSHIP & CC_OWNERSHIP & 0.909 \\
\hline & & B_OWNERSHIP & 0.896 \\
\hline \multicolumn{4}{|c|}{ 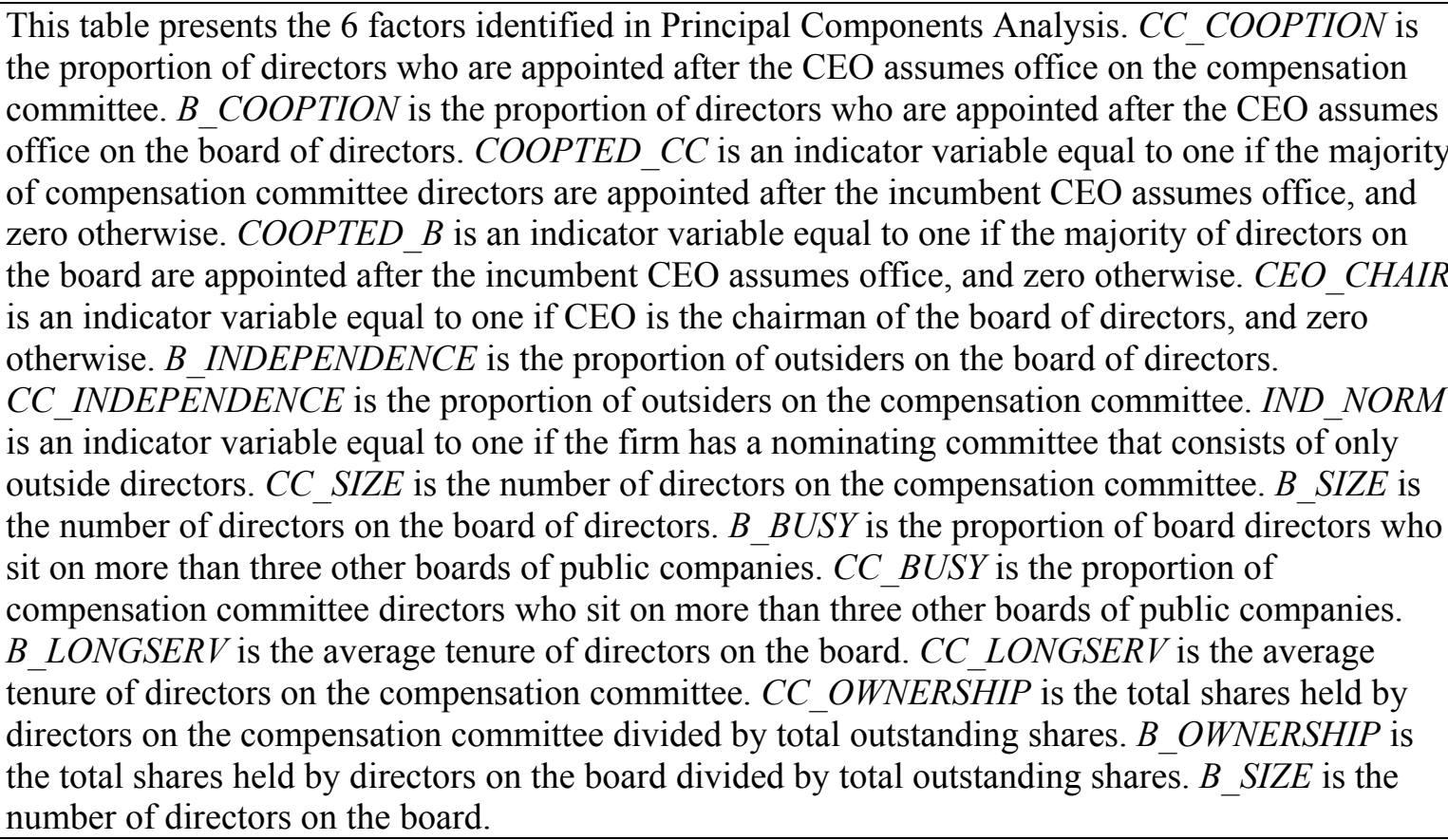 } \\
\hline
\end{tabular}


TABLE 13 Regression Results: The effect of board and compensation committee factors on CEO compensation

\begin{tabular}{|c|c|c|c|}
\hline Variable & Pred. Sign & Coeff. & p-value \\
\hline Intercept & & 5.220 & $(<0.01)$ \\
\hline CEO_POWER & + & 0.083 & $(<0.01)$ \\
\hline DIR_INDEPENDENCE & - & 0.013 & $(0.14)$ \\
\hline DIR_SIZE & $?$ & -0.071 & $(0.20)$ \\
\hline BUSY_DIR & + & 0.081 & $(<0.01)$ \\
\hline DIR_TENURE & + & 0.000 & $(0.49)$ \\
\hline DIR_OWNERSHIP & - & -0.091 & $(<0.01)$ \\
\hline SIZE & + & 0.366 & $(<0.01)$ \\
\hline$R E T$ & + & 0.109 & $(<0.01)$ \\
\hline$R O A$ & + & 1.139 & $(<0.01)$ \\
\hline CEO_TENURE & + & -0.002 & $(0.28)$ \\
\hline CEO_OWNERSHIP & $?$ & -0.003 & $(<0.01)$ \\
\hline Observations & & & \\
\hline $\mathrm{R}^{2}$ & & & \\
\hline
\end{tabular}

The table presents regression analysis of the effect of board and compensation committee factors on CEO compensation. InT PAY is the natural logarithm of CEO total compensation (EXECUCOMP data item TDC1). It is adjusted to 2003 dollars using Consumer Price Index. CEO POWER is the factor on which CC COOPTION, B COOPTION, COOPTED CC, COOPTED_B and CEO_CHAIR have high loadings. DIR_INDEPENDENCE is the factor on which $B$ INDEPENDENCE, CC_INDEPENDENCE, and IND_NORM have high loadings. DIR_SIZE is the factor on which CC_SIZE and $B \_S I Z E$ have high loadings. BUSY_DIR is the factor on which $B \quad B U S Y$ and $C C B B S Y$ have high loadings. DIR TENURE is the factor on which $B \_L O N G S E R V$ and CC_LONGSERV have high loadings. DIR_OWNERSHIP is the factor on which CC_OWNERSHIP and B_OWNERSHIP have high loadings. SIZE is the natural logarithm of sales. RET is the firm's stock return. $R O A$ is the earnings before extraordinary item divided by total assets. CEO_TENURE is the CEO tenure. CEO_OWNERSHIP is the proportion of outstanding shares held by CEO. The p-values are presented in parentheses and are two-tailed. The standard errors are heteroskedasticity robust, clustered by firm and year. For the sake of brevity, we do not report coefficient estimates for year indicators and $\mathrm{G}$ index dummies. 


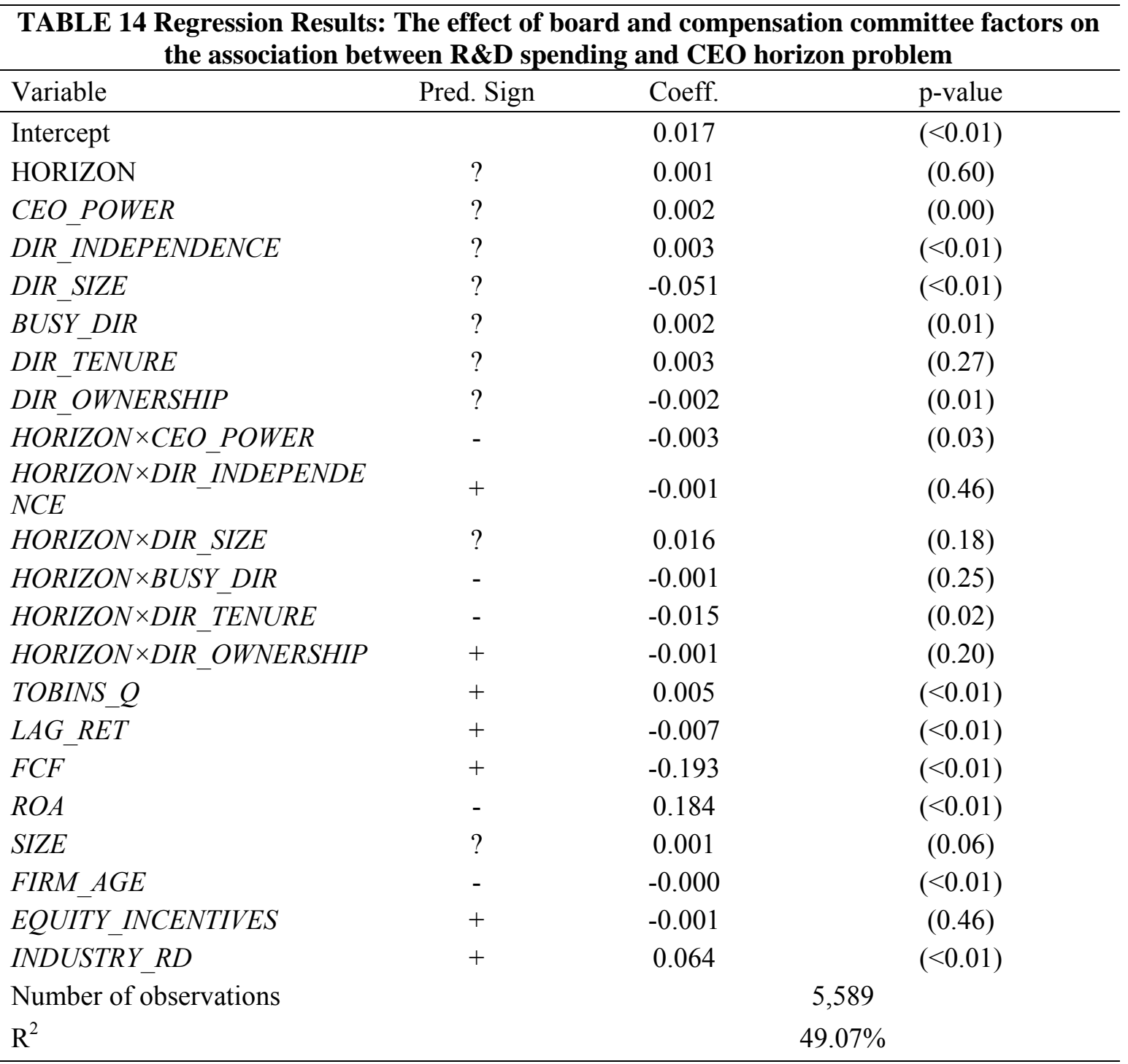


The table presents the regression analysis of the effect of board and compensation committee factors on mitigating opportunistic $\mathrm{R} \& \mathrm{D}$ reduction. $R D$ is the $\mathrm{R} \& \mathrm{D}$ expense scaled by total assets. HORIZON is an indicator variable equal to one if CEOs are in each of the final two years prior to their retirement, and zero otherwise. CEO_POWER is the factor on which CC_COOPTION, B_COOPTION, COOPTED_CC,COOPTED_B, and CEO_CHAIR have high loadings. DIR_INDEPENDENCE is the factor on which B_INDEPENDENCE, CC_INDEPENDENCE, and IND_NORM have high loadings. DIR_SIZE is the factor on which CC_SIZE and $B \_S I Z E$ have high loadings. $B U S Y \_D I R$ is the factor on which $B \_B U S Y$ and $C C \_B U S Y$ have high loadings. DIR_TENURE is the factor on which $B \_L O N G S E R V$ and CC_LONGSERV have high loadings. DIR_OWNERSHIP is the factor on which CC_OWNERSHIP and B_OWNERSHIP have high loadings. TOBINS_ $Q$ is calculated as the market value of equity plus the book value of debt, all scaled by total assets. $L A G_{-} R E T$ is the firm's stock return from previous year. $F C F$ is the operating cash flows plus R\&D expense minus capital expenditures, all scaled by sales. ROA is operating net income before R\&D expense scaled by assets. SIZE is the natural logarithm of total assets at the beginning of the current year. FIRM_AGE is the natural logarithm of the number of years between year $t$ and the first year the company listed on Compustat. EQUITY_INCENTIVES is the natural logarithm of the CEO's dollar wealth increase from a $1 \%$ change in stock price, as measured in Core and Guay (2002). INDUSTRY RD is the average R\&D expenditures of other firms in the same 2-digit SIC industry. The p-values are presented in parentheses and are twotailed. The standard errors are heteroskedasticity robust, clustered by firm and year. For the sake of brevity, we do not report coefficient estimates for year indicators. 


\begin{tabular}{|c|c|c|c|}
\hline \multicolumn{4}{|c|}{$\begin{array}{l}\text { TABLE } 15 \text { Regression Results: The effect of board and compensation committee factors on } \\
\text { the association between discretionary accruals and CEO horizon problem }\end{array}$} \\
\hline Variable & Predicted Sign & Coefficient & p-value \\
\hline Intercept & & 0.212 & $(0.08)$ \\
\hline HORIZON & $?$ & 0.012 & $(0.71)$ \\
\hline CEO_POWER & $?$ & -0.019 & $(0.08)$ \\
\hline DIR_INDEPENDENCE & $?$ & -0.011 & $(0.36)$ \\
\hline DIR_SIZE & $?$ & 0.130 & $(0.08)$ \\
\hline BUSY_DIR & $?$ & -0.005 & $(0.61)$ \\
\hline DIR_TENURE & $?$ & 0.002 & $(0.42)$ \\
\hline DIR_OWNERSHIP & $?$ & -0.003 & $(0.39)$ \\
\hline HORIZON $\times C E O \_P O W E R$ & + & 0.018 & $(0.30)$ \\
\hline $\begin{array}{l}\text {HORIZON } \times \text { DIR_INDEPEND } \\
\text { ENCE }\end{array}$ & - & 0.018 & $(0.61)$ \\
\hline HORIZON $\times D I R \_S I Z E$ & $?$ & -0.439 & $(0.02)$ \\
\hline HORIZON $\times$ BUSY_DIR & + & 0.017 & $(0.28)$ \\
\hline HORIZON $\times D I R \_T E N U R E$ & + & -0.192 & $(0.14)$ \\
\hline $\begin{array}{l}\text { HORIZON } \times \text { DIR_OWNERSHI } \\
P\end{array}$ & - & 0.023 & $(0.10)$ \\
\hline EQUITY_INCENTIVES & + & 0.047 & $(0.35)$ \\
\hline SIZE & - & -0.008 & $(0.40)$ \\
\hline STD_CASHFLOW & $?$ & -0.793 & $(0.07)$ \\
\hline$S T D \_R E V$ & $?$ & 0.141 & $(0.20)$ \\
\hline STD_SALESGROWTH & $?$ & -0.008 & $(0.90)$ \\
\hline OLDFIRM & $?$ & 0.019 & $(0.42)$ \\
\hline LEVERAGE & $?$ & -0.002 & $(0.97)$ \\
\hline MARKETTOBOOK & $?$ & -0.005 & $(0.32)$ \\
\hline Number of observations & & & \\
\hline $\mathrm{R}^{2}$ & & & \\
\hline
\end{tabular}


The table reports regression analysis of the effect of board and compensation committee factors on mitigating opportunistic accruals management. CEO_POWER is the factor on which CC_COOPTION, B_COOPTION, COOPTED_CC,COOPTED_B, and CEO_CHAIR have high loadings. DIR_INDEPENDENCE is the factor on which $B \_I N D E P E N D E N C E$,

CC_INDEPENDENCE, and IND_NORM have high loadings. DIR_SIZE is the factor on which $C C$ SIZE and $B$ SIZE have high loadings. BUSY DIR is the factor on which $B$ BUSY and $C C B U S Y$ have high loadings. DIR TENURE is the factor on which $B$ LONGSERV and $C C$ LONGSERV have high loadings. DIR OWNERSHIP is the factor on which CC_OWNERSHIP and B_OWNERSHIP have high loadings. EQUITY_INCENTIVES is the dollar change in CEO's wealth from a $1 \%$ change in stock price, as measured in Core and Guay (2002), then normalized by the sum of the dollar change, salary and bonus. SIZE is the natural logarithm of total assets at the beginning of the current year. STD_CASHFLOW is the standard deviation of cash flows from operations deflated by total assets over the current and previous four years. $S T D_{-} R E V$ is the standard deviation of sales deflated by total assets over the current and previous four years. STD_SALESGROWTH is the standard deviation of sales growth over the current and previous four years. OLDFIRM equals one if a firm is listed on Compustat for more than 20 years, and zero otherwise. LEVERAGE is total liabilities deflated by total assets.

MARKETTOBOOK represents deciles of market value of assets divided by the book value of assets ranked within each year. The $\mathrm{p}$-values are presented in parentheses and are two-tailed. The standard errors are heteroskedasticity robust, clustered by firm and year. For the sake of brevity, we do not report coefficient estimates for year indicators, $G$ _index indicators, exchange indicators, and industry indicators. 
VITA

\section{RUONAN LIU}

2003-2007

B.S. in Accounting

Shandong Economic University

Jinan, China

$2008-2010$

M.S. in Accounting

State University of New York at Binghamton

Binghamton, New York

2010-Present

Doctoral Candidate in Accounting

Florida International University

Miami, Florida

\section{PRESENTATIONS}

Lin, S. W., Liu, R., and Wang, C. (2013, April). Earnings Management and Equity Incentive Gap between CEOs and CFO. Paper presented at Florida International University Accounting Seminars, Miami, Florida.

Liu, R., (2013, August). Compensation Committee Characteristics and Earning Management. Paper presented at American Accounting Association Annual Conference, Anaheim, California. 